University of Rhode Island

DigitalCommons@URI

Open Access Dissertations

1982

\title{
A Social Cognitive Analysis of Stereotyping
}

Cathryn M. Noseworthy

University of Rhode Island

Follow this and additional works at: https://digitalcommons.uri.edu/oa_diss

\section{Recommended Citation}

Noseworthy, Cathryn M., "A Social Cognitive Analysis of Stereotyping" (1982). Open Access Dissertations. Paper 1023.

https://digitalcommons.uri.edu/oa_diss/1023

This Dissertation is brought to you for free and open access by DigitalCommons@URI. It has been accepted for inclusion in Open Access Dissertations by an authorized administrator of DigitalCommons@URI. For more information, please contact digitalcommons-group@uri.edu. 


\title{
A SOCIAL COGNITIVE ANALYSIS OF STEREOTYPIMG
}

\section{BY}

\author{
CATHRYN M. NOSEHORTIY
}

A DISSERTAIION SUEMTTTED IH PAPTEAL FULFILLMFNT OF FHE REQUIREMENTS OF THE LEGREE OE DOCTOR OE PHILOSOPHY

IN PSYCHOLCGY

UN IVERSITY OF RHCDE ISLAME

1982 
The present investigation appliec a social cosnitive approach to stereotypes. The emphasis of this approach on the limitations of the information processor, focuses on the mechanisms people emelcy to cope with vast anounts of information input and the biases inherent in such mechanisns. One of the most eervasive of these mechanisms, categorization, is also an essential element to stereotyping. Consequently, this apyroach leacs to a view of stereotypes as categorization schemas with attributes such as race or sex tagged to category labels. This position was explored using the female sex-role stereotype as an exemplar. The structure and content of stereotycic categorization schemas were exanined in a series of eight studies.

Stereotypic categories and their attributes were celineated solely from subject-gererated protocols, which were obtained without imposir.s "a priori" restrictions on subjects as to rumber, type or content of stereotypic categories. This free-format methodology yielced remarkably consistent results. Five stereotypic categories of women emergea; housewife, career womar, sex object, female athlete anc women's libber. Examination of the attributes that subjects used to cescribe these roles irciicateo that the first four roles were cuite distinct. This was oonfirmec by factor analysis oz a sex-role scale which 
incorgorated the rost Erequently used attrikutes for each role.

The structural organization of stereotypic categories was also examined and was found to be essentially the same as that reported for other person and object categories.

The meaiaticnal function of stereotypic schemas vas assessed in two studies. In a recognition memory paradigm, stereotypic categories were found to bias memory toward the stereotype, while in a free-recall task, sterectypic attributes appearec to be groupec together in memory.

These data clearly support the social cogritive interpretation of stereotypes as categorization schemas that Eacilitate our information processing, albeit in a biased fashion. They provicie converging evidence for the titility of a social cognitive aporoach to stereotypes both conceptualy and methocologically. 
Dr. Albert lott served as my najor professor, mentor and Eriend for the past three years. Fis ferforrance in all roles can only be cescribed in superlatives. The cher merbers of my progran comittee, Dr. Charles Collyer, Dr. Leo Carroll aná Dr. Paul Florin, have been ecually helpful and cooperative, particularly in meeting ny impossible schecule. I thank them.

I gratefully acknowlec̆ge Iinancial support Eor this research from the Social Sciences and Humanities Research Council of Canecie ano from lenorial tniversity of newfoundanc. I wolic like to especially thank the faculty of the Psychology Department of hemorial university, who bave demonstrated the true meaning of İellowship among colleagues. In particular, Fony Simmonds, Enir Andrews anc Virginia Grant were invaluable in collecting cata and Pat Eenderson dic the independent thematic analyses. I thank Dean Frecerick Alarich of fiemoria! university who has been a source of support anci guiciance curing this cegree and Dr. Peter Merenca who has given rie an invaluatle appreciation for good science and nethoäs.

Thanks also to Phillip Sharkey who taught me the intricacies anci iciocyncracies of the UPI computer systeri, and to Denise Ferry, marie Sharpe, lichael roods and Lynn roocis, who have been special friends in sharing their Iives ancicieas with me and helping whenever needed.

Finally, ny ceepest appreciation to the trio fellow graduate students who've been integral to this cesree and to my life, Pall Moseworthy and Clarence Button, whose contricuticns are beyondi words. 
Abstract

Acknowleagenents

List of Figures

List of Tables

I. The Cognitive Structure and content of

the Female Sex-role stereotype.

Stuay 1. Construction of stereotypic

categories

Study 2. Construction of sterectypic

sub-categories

Stuāy 3. Valication of female sex-role

stereotype taxonomy

Stuogy 4. The structure and content of

stereotypic categories

Study 5. The basic-level category in

categorization schemes

Study 6. Validation of the midale-level

stereotypic categories

II. The Eunction of Stereotypic Schemas

Experiment 1. Recogrition memory test 64

Experiment 2. Organization in free recali 82

Discussion

References 


\section{List of Figures}

Page

Fig. 1 An example of a common object taxonomy. 4

Fig. 2 An example of a person tamonomy. 6

Fig. 3 Taxonomy of the female sex-role stereotype.

Fig. 4 Average number of attributes at each level of abstraction cf the female sex-role taxonomy.

Fig. 5 Average number of attributes at each abstraction level for each of the midale level categories and their asociatec suborcinate roles.

Fig. 6 Design of the recognition memory experiment.

Fig. 7 Interaction of Explicit-Implicit instructions and Item type.

Fis. 8 Interaction of Prototype ard Item type.

Fig. 9 Interaction of Prototype and Item type. 
Page

Table 1. Categories of women that met the 50

per cent listing criterion.

Table 2. Number of subjects who classified five

female roles on the basis of types,

traits or both.

Table 3 . Total number and mean number of types listed for five female roles.

Table 4. Total number of different subcategory

types listed for five female roles by sex.

Table 5. Subcategories listed for the five female roles that met the 50 per cent inclusion criterion.

Table 6 . Number of attributes listed for each role category.

Table 7 . Mean and percentage of attributes of different types at each level of abstraction.

Table 8 . Number of shared and distinctive attributes across mid̄ile and suborcinate categories.

Table 9. Shared attributes across midile level stereotypic categories of women. 
Table 10. Shared attributes across stereotypic

sub-categories of women.

Table 11. Nimber of subjects who correctly

identified the midale level category

across roles $(n=17)$.

Table 12. Attributes for each of the five midale

level categories selected for the

sex-role scale.

Table 13.High factor loadings for rotated factor matrix of 37 scales.

Table 14.Sumary of items used to describe good and peripheral exemplars of a career woman.

Table 15. Means and standard deviations of acquisition and non-acquisition items for treatment groups.

Table 16. Analysis of variance of acquisition and non-acquisition memory scores across treatments.

Table 17 . Means and standard deviations of related and unrelated items in the recognition memory task. 
Table I8. Analysis of variance of related and unrelated items across treatments.

Table 19.Stimulus items used in the free recall task.

Table 20.Shared adjectives across roles in the Clifton et al(1976) study.

TabIe 21 .Percentage of distinctive attributes for roles in the present and Clifton et al(1976) studies. 
Recent interest in social cognition has lec tc the direct and explicit stuciy of cognitive processes involved in person perception phenomena (Abelson,1976; Cantor \& Mischel,1979; Hamilton,1976;1979; Fanilton, Katz \& Leirer,1980; Hastie \& Carlston,1980; Hastie,1980; Schank \& Abelson,1977; Srull \& Wyer,1980; Taylor \& Fiske,1978; Wyer \& Srul1,1980). The result has been a conceptualization of and approach to person perception that emphasizes process, rather than enci-points ; active, dynamic aspects rather than static ones; and the limitations of the information processor in attempting to process the vast amounts of incoming information (Schneider, Hastorf \& Ellsworth,1979).

Interest in the implications of this approach for the study of stereotypes is currently emerging. Historically, stereotyping has been ciscussed in terms of motivational, dynamic factors and/or social-learning and acculturation processes (Brigham,1971; Hamilton,1976). In contrast, the social cognitive approach views stereotyping as a result of biases in the way we process information about others, i.e., normal cognitive functioning can produce differential perception of people/groups (Cantor \& Mischel,1979; Hamilton,1976;1979; Taijfel, Billig, Bundy \& Elanent,1971; Taylor \& Fiske,l978).

In particular, central characteristics of our 
cognitive processing mechanisms produce systematic biases that can explain stereotyping quite well. These include the categorization process, responsiveness to stinulus salience and the development of illusory correlations. From a cognitive point of view, these mechanisms are means of recucing the enormous complexity of the social worlc. They are highly functional processes that lend organization to the social environment and probably the coding and retention of information about it (Fiske, Etcoff \& Ruderman,1978; Hamilton, 1979).

\section{The Categorization Process and Prototypes}

Of these mechanisms, the most essential element to stereotyping is categorization. Differential perception, an obvious prerequisite to stereotyping, involves the categorization of people into a variety of groupings (Cantor \& Mischel,1979; Ehrlich,1973; Hamilton,1979). Indeed, the tendency to categorize both objects and people into groups or types is a pervasive one (Allan \& Wilder,1975; Eem,1978; Cantor,1978; Cantor \& Mische1,1979; Cohen,1977; Fiske \& Cox,1977; Hamilton, Ratz \& Leirer,1980; Hastie,1980; McGuire, McGuire, Child \& Fujioka,1978; Mischel, Jeffrey \& Patterson,1974; Quine,1969; Rosch, Mervis, Gray, Johnson \& Boyes-Braem, 1975). Rosch and her colleagues (Rosch,1975;1978; Rosch \& Mervis,1975; Rosch et a., 1976) have concuctec eitensive Hesearch on the structure and 
function of cbject categorization anc have found that such systems are orçanized in hierarchical tayonomies that consist of three levels of abstraction /inclusiveness (see Fig.l). The optimal level of abstraction in such taxonomies appears to be the middle level, since it represents the intersection of maximum detail anả minimum cognitive effort. This moderate level conveys a rich set of information about the objects within the category using a few category labels, while minimizing the cognitive effort involved in making too many fine discriminations.

Natural object categories, as studiec by Rosch and her colleagues, appear to represent "fuzzy sets", that is, nembers of a category vary in ciegree of nembership (prototypicality) with many ambiguous, borderline cases resulting in overlapping and fuzzy boundaries between categories (Lakoff,1972; McCloskey \& Glucksberg,1978; Rosch, 1975).

Categories, then, are organized around prototypical members (clear, central exemplars), with less prototypical members forming a continuum away from the central Frototypical members (Rosch,1975). Since categorization represents a probabilistic decision basec on cegree of prototypicality, it is best studied using clear, central exemplars rather than ambiquous, borderine cases. Such prototypes are especially useful in processing incoming information, since they appear to be easier to learn, to classify, to name and to image (Rosch,1976; Rosch \& 


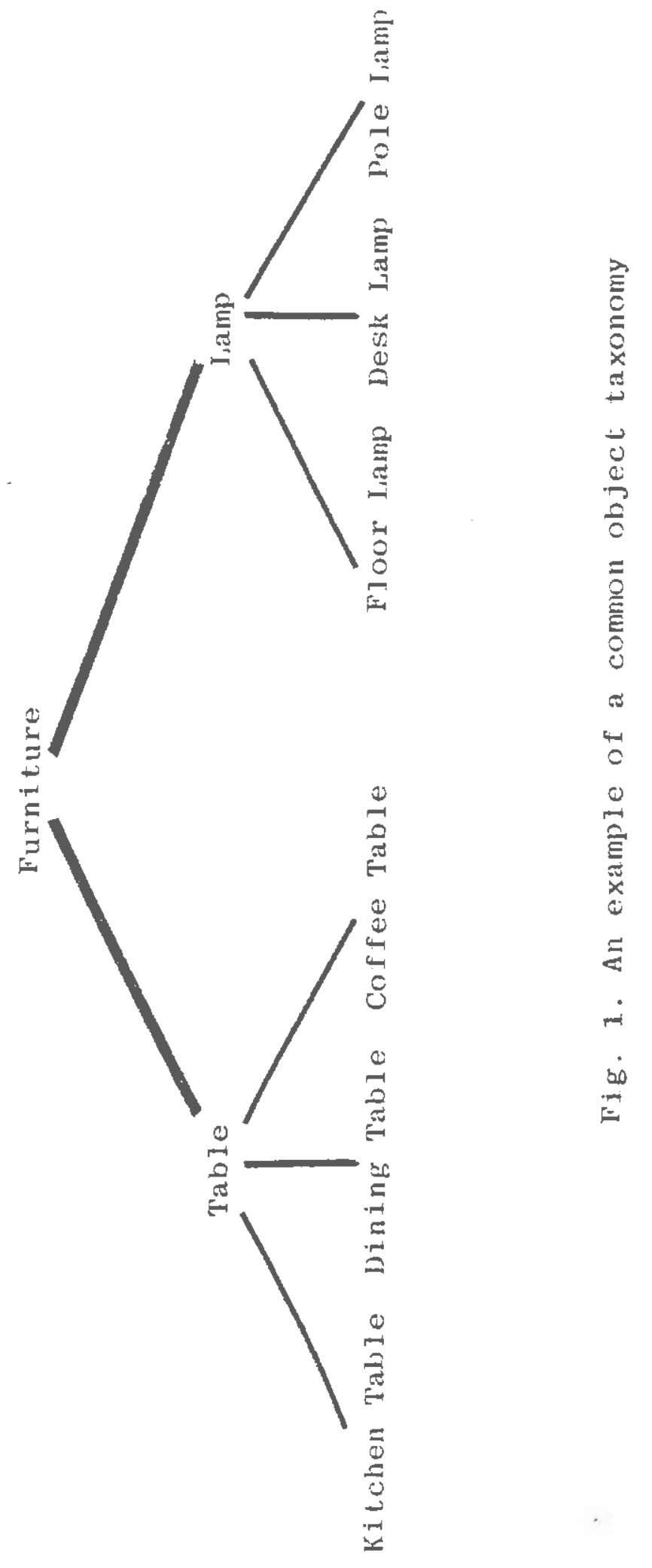


Fervis,1975; Fversky,1977). Categorization scheres in the object domain, then, serve to simplify what would otherwise be overwhelming data and thence to lend economy and coherence to our knowledge about the worlc.

In the person domain, studies of how people freely describe and tyce one another also suggest the extensive use of categorization schemes (Abelson,1976; Eem,1978; Cohen,1977; Fiske \& Cox,1977; McGuire et al,1978). Rosch's procedures have been aciaptec to explore the structure of categorization schemes in the perscn comain (Cartor,1973; Cantor \& Mischel,1979). These researchers constructe $\bar{a}$ a variety of person taxonomies basec on social and occupational roles, personal attributes anc psychiatric disorders that were frequently used by naive observers and that varied in levels of abstraction (See Fig. 2). At the superor innate level, they began with. four categcries, the extraverted person, the cultured person, the emoticnally unstable person and the person committed to a belief. For each of these, two middle and six suborcinate level items vere constructed by the experimenters, which contained less inclusive categories, by araving on categories used in everyday conversation and in the social psychological literature on stereotyping and categorization.

To verify the hierarchical structure of these four taxonomies, Cantor and Mischel (1979) hac five juages sort the categories using a carc sorting task. First, the jucges placed all items under the four superordinate latels, then 
they subdivicied each pile into as many. smaller, less inclusive categories as they felt existec in each of the four units. Hierarchies with three levels of inclusiveness thus resulted. As expected, when the data were submitted to a hierarchical cluster analysis, the person categories clusterec appropriately into subordinate and midale level categories under the four superordinate types. Following Rosch et al (1976), the basic level categories were determined by having subjects list the attributes that they believed to be characteristic of and common to the members of each category within the person taxonomies. Pesulting attribute lists were scored for consensus and attributes retainec that at least two subjects had listed. These lists were then given to four judges who rated the percentage of members of the category for which each attribute woulc be true. Final lists that received a mean rating of 50 per cent across the four jugges were then compiled. The 50 per cent inclusion level was usec to reflect the inherently "fuzzy" nature of category bouncaries.

Final lists were exanined for relative richness(number of attributes) at each taxonomic level. Increasing gains in number of attributes were found from superorainate to midale to subordinate levels, the last maximizing vividness and concreteness of the images associated with it. The opposite pattern was found for levels of differentiation. Categorizations at the superordinate level were the most differentiated, that is, 
non-overlapping, those at the middie level next, and those at the suborcinate level the least cifferentiatec.

Cantor and Mischel (1979) concluded that, like object categorization, person categorization has as its basic/optimal level the midale level of inclusiveness and abstraction. This level maximizes the intersection of richness, differentiation, and vividness while reducing the cognitive load entailed in distinguishing too many categories. This level should be optimal in describing what a person is like in general, to distinguish how two people differ from each other and to apply one's knowledge of person types to flesh out an impression of a particular person. In contrast, to capture the gist of a person, one would move to a higher level of abstraction while to gain a more vivid, specific image, one would move to a lower level.

The assignment of individuals to a particular category appears to be based on a judgement of the degree of prototypicality. Since categories in both the object and person domain represent essentially "fuzzy sets" without clear-cut boundaries, the distinctiveness of categories seems to be achieved by considering the category's clear instances rather than its boundaries (Cantor,1978; Rosch,1978). Cantor(1978) examined prototypicality judgements by asking subjects to describe as fully as possible the attributes of extraverts they knew well anc considered to be poor, moderate and good examples of that prototype. The descriptions were read by another group of 
subjects who rated the attributes for degree of prototypicality with respect to extraversion. The descriptions and ratings were highly correlated ( $r=.87$ ) and prototypicality judgements were related to the number of associations with the category and differentiation from contrasting categories. Similar results have been reported for object judgements (Rosch \& Mervis,1975; Tversky,1977). when only scant evidence is available, prototypicality judgements appear to be made on the basis of central category attributes. Cantor and Mischel(1979) asked subjects to choose the more prototypical extravert from among six pairs of characters, that varied in the number of episodes in which they showed prototypic versus less central category attributes. Subjects consistently chose the character who exhibited the more prototypical attribute.

On the basis of the extensive research program reviewed here, Cantor and Hischel(1979) have argued that prototypes function as cognitive schemas in processing information about others. Association with a prototypical category exemplar acts as an organizational theme that structures the encoding of new information about the person, provides expectations about future behaviour and aids in the retrieval of information about that person. The more a person fits a prototype, the more easily information about that person is categorized, recalled and recognized. 
2. Function of Categorization Schemes

Considerable evidence from cognitive psychology supports the claim that people learn and remember information by actively categorizing and coding input according to well-learned conceptual schemata abstracted at the time of input (Franks \& Bransford,1971; Posrer \& Keele,1968; Reed,1972; Reitman \& Bower,1973). For example, Posner and Keele(1968) and Reed(1072) have shown that subjects in a classification learning paradigm abstract a prototypic visual pattern which is then used as a standard against which to compare rew patterns. In a recognition menory task, subjects falsely recognize items that closely resemble the abtracted prototype (Franks \& Eransford,1971; Posner \& Keele,197C; Reitman \& Bower,1973). Schank and Abelson (1977) and Minksy (1975) have demonstrated the existence of conceptual schemata for everyday kehavioural episodes. Their work suggests that feople use these schemata to generate missing information in orcer to fill out an anticipated schema of events.

Evidence indicates that person prototypes function in a similar manner. Cantor and Mischel (1977) presented subjects with trait lists describing a prototypic extravert, introvert and two control characters. These vere presented under either explicit conditions (the prototype was named) or implicit conditions (the prototype vas rot menticnea). On a recognition memory task, subjects exhibited a clear 
memory bias consistent with the prototype, expressing greater confidence that they had seen non-represented but conceptually related items as opposed to non-represented, unrelated items. This effect was not found for the control characters. Similarly, in a free recall paradigm, Cantor and Mischel (1979) manipulated the degree of prototypicality of stimulus characters. On a free recall task, subjects recalled more information consistent with the prototype when the stimulus character was a "good" exemplar than when the character was less prototypical. They also wrote more in personality impressions of a prototypic character than a less prototypic character. These data suggest that prototypes do function as schemata and that a comparison-to-prototype process is involved in processing social stimuli when the prototype is activated.

Tsujimoto (1978) replicated these findings using both different prototypes and different procedures. He constructed three prototypes; a positive prototype, consisting of six positive traits; a negative prototype, consisting of six negative traits; and a novel prototype, consisting of three positive and three negative traits. Through systematic transformation or deletion of traits, he constructed a set of acquisition lists that varied in degree of similarity to the prototype lists. The original prototype lists were not presented but they were the most typical exemplars of the acquisition list sets. In a recognition memory task, recognition confidence was a 
positive, linear function of the degree of similarity to the prototype list and was highest for the prototype list. Since subjects were not presented with the prototype lists during acquisition, they must have abstracted, as opposed to simply memorized, the prototype. Moreover, this finding vas true of the novel prototype, indicating that prototype abstraction operates across a wide range of contexts rather than just those in which the prototype is normative. These data provide strong converging evidence for the meciational function of prototypes.

3. Locus of the Biasing Effects of Categorization Schemes

Several investigators have attempted to determine how the comparison-to-prototype process systematically biases memory. Duncan (1976) showed subjects a videotape of a woman having dinner. Half of the subjects were told that she was a waitress, the other half that she was a librarian. When asked to recall factual information about the tape (e.g., did the woman wear glasses? drink beer or wine?), subjects were most accurate when the information to be recalled was consistent with the prototype they had been given. These results suggested that the biasing effect occurred during the encoding stage, with information being coded in terms of the activated prototype.

A more direct test of the locus of the biasing effect of prototypes on memory was performed by Rothbart, Evans and 
Fulero(1979). They gave subjects behavioural cescriptions of either a "friendly" or "intellectual" group of men. For half of the subjects, this expectancy was induced prior to the presentation of behaviours, while the other half received the expectancy afterwards. Subjects showed superior recall and higher frequency estimates of behaviours that were consistent with the prototype but only when the expectancy was induced prior to stimulus presentation, again indicating an encoding bias.

Wyer and Srull(1980) also reported an encocing bias of category information on memory. They inauced a category expectancy (i.e., hostility) by having subjects initially complete a sentence construction task in which all terms implied hostile behaviours. Subjects also read a description of behaviours of a target person that were ambiguous with respect to the primed category and rated the target person on a number of trait dimensions. The number of hostile-related behaviours, time between priming the trait category and presentation of the behavioural descriptions and time between descriptions and judgements, were varied. Results showed that when subjects experienced delay between activation of the trait category and acquisition of the stimulus material, their ratings of the target person in terms of the primed category increased with the number of times the category had been activated but decreased with length of delay. In contrast, when the delay was between stimulus presentation and making a judgement, 
target ratings in terms of the prined category increased with both number of activations and length of delay. None of these effects occurred in a further condition, in which the trait category was activated after information had been encoded into memory (i.e., after presentation of the behavioural cescriptions). These data suggest that the categories used to interpret behaviour depend on the accessibility of categories at the time the information is received. Information appears to be encoded in terms of activated trait categories, which then influence subsequent judgements since they represent how the information is codeci in memory.

In a similar stuäy, Higgins, Rholes anä Jones(1977) reported that priming a trait category (e.g., reckless, persistent) leads to juagements of a target in terms of that category. Like Wyer and Srull(1980), they found that the delayed effect of priming was greater than its immediate effect on judgements. In both of these studies, the categories were unobstrusively primed, indicating the powerful biasing effect of prototypes on processing information about others.

Although the majority of studies suggest an encoding bias of prototypes on person memory, there is some incication that category information can also bias retrieval. Synder and Uranowitz(1978) gave subjects a detailed case history of a character named "Betty" to reac and, one week later, asked them to recall information about 
the case history. At that time, they were tola that "Eetty" was either a lesbian or was leading a heterosexual lifestyle. Information recalled tenajed to be consistent with the prototype subjects had been given.

The biasing effects of categorization schemes and prototypes on processing information about others, then, are well documented and their application to the study of stereotypes evident. A stereotype may, in effect, be a form of a prototype, a functional schema that aids in orgarizing and interpreting information about others. A number of recent studies have examined this proposition.

4. The Role of Stimulus Salience

Taylor, Fiske, Close, Anderson and Ruderman(1977) have shown that physical and social ciscriminators, such as sex and race, are used as ways of categorizing people and organizing information about them. They had subjects observe a group discussion of racially or serually mixed groups and then asked them to recall who had said what during the discussion. If race was used to categorize incoming information, then subjects shoula make more intra-race errors than inter-race errors. The sane prediction would be made for sex. Results supported these hypotheses. Tayior et al(1977) interpreted these results in terns of salience effects since it is well known that 
salient stimuli attract our attention and stereotypes usually involve especially salient stimuli (e.g., sex, race, etc.).

In a further study, Taylor and Fiske(1978) manipulated salience via numerical distinctiveness (i.e., black solo/white group; female solo/male group,etc.) and found that salient individuals were seen as more prominent and were rated nore extremely than the same individuals in integrated groups. Solo men anc women were more likely to be perceived in special roles than those in mixed groups. Moreover, these roles were highly sex-typed. Field studies of solo women in work organizations (Kanter,1977; Wolman \& Frank,1975) also found that such women were seen as playing out highly sex-typed roles. It appears that salience, by virtue of category membership, increases perceptions of category representativeness, e.g., a solo woman or black is often seen as being typical of the entire sez or race. Indeed, Guritz and Dodge(1977) found that mere mention of membership in a group (i.e., a sorority) increased stereotypic attributions to indivioual members.

5. The Role of Illusory Correlation

Research on illusory correlation has also demonstrated cognitive biases in our information processing. Hamilton and Gifford(1976) presented subjects with 39 stimulus persons, each cescribec performing some cehaviour. 
Each person was simply identified as belonging to Group A or B, Group $B$ always being smaller than Group f.. A majority of positive behaviours, in a ratio of $S: 4$ fositive/i.egative, was presented for both groups. As a result, Group $B$ and negative behaviour were ảistinctive because of their lower frequency of occurrence. When subjects were asked to estimate the occurrence of positive/negative behaviours for each group, they overestimated the co-occurrence of negative behaviours with the smaller group. Even though the relative frequency was the same for both groups, the shared distinctiveness of negative behaviours and minority status resulted in the formation of an illusory correlation. Furthermore, the illusory correlation led to the differential evaluation of the two groups, with the minority group being judged as less desirable. In a further study, Hamilton and Gifford(1976) replicated these findings with positive behaviours being distinctive, i.e., a positive illusory correlation formed with Group $B$ and subsequent evaluation of Group $B$ as more desirable than Group A.

Such biases can also serve to maintain previously developed beliefs. Hamilton and Rose(1980) had subjects read trait descriptions of various occupational groups that varied in being confirming, neutral or disconfirming with respect to the stereotypic conception of the occupation. When subjects were asked to estimate the frequency of traits associated with each occupation, they overestimated the frequency of confirming traits, even though all trait types 
occurrec with equal frequency. When a relationship cilc exist, subjects perceived it to be stronger if it confirmea the stereotype. These results parallel those reported earlier that indicated superior recall for expectancy confirming rather than cisconfirming events (Rothbart et al,1979) .

\section{Cognitive Sias and Stereotypes}

It appears, then, that factors related to the categorization of, attention to and processing of information about social stimuli can result in social judigement patterns similar to stereotyping. Selectively attending to salient aspects of the environment leads to exaggerated evaluations and perceptions of prominence, and stereotypes are frequently characterized by especially salient stimuli such as sex, race, or minority status. The cognitive processes by which individuals develop correlational concepts are also subject to consicierable bias, and stereotypes reflect correlational beliefs. The formation and use of categorization schemes have also been shown to lead to biased coding and retention of social information, and stereotypes appear to operate like other categorical systems, with attributes such as sex and race tagged to category labels or prototypes.

The extension of this approach to the study of the content and structure of stereotypes, however, has thius far 
receivec little attertion. Voreover, the approach should be applicable to any stereotype area. The sex-role stereotype was chosen as a stereotype exemplar for a number of reasons. The issue of content and structure is particularly relevant to sex-role stereotypes, since research and measurement cevices in this area are based on the implicit assumption that sex stereotypes represent a single category for each sex that conform to the traditional roles of males anc fenales. The Eemale stereotype forms a warmth-expressiveness cluster and the male stereotype a competency-instrumental cluster of traits (Broverman, Vogel, Broverman, Clarkson \& Posenkrantz,1972; Kelly \& Worell,1977; Pedhazur \& Tetenbaur,1979; Dleck,1975; Rubie $\&$ Ruble,1980).

Recently, however, the single category assumption has beer challenged. Clifton, NcGrath and Wick(1976), based on a review of the family literature (e.g., Klockholm,1953; Turner, 1970) and interviets with college studerts and. midale- ciass suburbanites, icentified five sex-role categories for women; housewife, bunny, clubmoman, career woman and woman athlete. They presented college subjects with an adjective checklist and asked them to check those which described each of the five categories. If there was a single stereotype of women, then all five role categories should elicit common adjectives. Instead, however, they found that suijects attributed quite distinctive agjectives to the various roles. In particular, they found strong 
evicence of a distinctive stereotyge of the housewife role whose content paralleled the traciticral sex-role stereotype results. In acaition, two other cistinctive stereotypes emerged, one for bunny and the other encompassing more non-träitional alternatives such as career voman and athlete. Unfortunately, the Clifton et al(1976) study enployed a predetermined checklist, so that subjects were limited in the response they coulc make. Woreover, the adjectives were selected by the researchers rather than being generated fron subjects' responses.

This is important since it has been shown that the format and methods used to elicit stereotypes can influence the results obtained (Brannon,1978; Erlich E Rinehart,1965; Cicone \& Ruble,1978). For example, Erlich and Rinehart(1965) compared responses on a checklist to a free-response format about ethnic stereotypes. They found that the checklist cata contained three tines as many attributes as the free-response data, but was less substantively cohesive and ircluded more necative traits. Moreover, the trait lists obtained under the tho conoitions were considerably different.

It appears that the widely accepted content of sex-role stereotypes may be more a function of the methodology employed than a reflection of reality. If you ask subjects to describe a single stereotyce, they will; if you ask them to describe several subcategories, they also oblige. Clearly, the content of sex-role stereotypes neecs 
to be assesseci fron a cifferent perspective. St the sane time, examination of the medictional function of sex-role stereotypes wolid extend the categorization mocel anc woula provide further support for the social-cognitive approach to the study of stereotyping.

The present investigation, therefore, was an attempt to extend the perspective and methods described here to the study of stereotyees, using the female sex-role stereotyve as the exemplar. Specifically, the research was cesigred to examine the cocnitive content, structure anc furction of the fenale sex-role stereotype. The followirg guestions were adöresseä:

1. What is the content and cognitive organization of the female sex-role stereotype, i.e., is it organized in a similar fashion, to other person grototypes in a hierarchical taxonomy? That is the basic/optimal level category that maximizes information/cognitive economy? 2. Do sex-stereotypic categories function as cognitive schemas to organize, code and select person information, i.e., do they mediate memory and perceptions about others? 
I. The Cognitive Structure and Content of the Female Sex-role stereotype

Study 1. Construction of Stereotypic Categories

Both Rosch's(1976) and Cantor's(1978) procedures to study the structure of categories began with "a priori" taxonomies of object and person categories, which may be unnecessarily artificial. This is especially true with categories that have real social consequences, such as sex stereotypes, where it is an important issue in and of itself to examine the validity of the content of the category. It was necessary, therefore, to assess whether subjects' conceptions of the stereotype were those that researchers have implicitly and explicitly assumed. The method describea here represents a major departure fom previous work, in attempting to construct both stereotypic categories and their attributes from subjects' responses. Study I was designed to determine the stereotypic category(s) that people use to cescribe women. 
Methoa

\section{subjects}

Subjects vere 193 college freshnen, 103 females and 85 males with a mean age of 18 , randomly selected from the introcuctory psychology class. This course has an enrollment of approximately 1500 students taught in classes of about 35. Subjects participated as part of the course experience although they could ont out if they wished to co so.

\section{Drocedure}

Subjects were tested in class groups of approximately 33 each. The Experimenter, who was a female for half of the groups and a rale for the other half, explained that the research concerned how pecple describe each cther and that they would be asked to respond to one question about women; that there were no right or wrong answers; and that the researchers were interested in their opinions. Subjects were then given five minutes to respond to the following statement, distributed to each of them:

"Name as many different types of women as you can. You shoula have a sufficient number of types that each woman could fit into at least one category."

Age and sex of each subject were also recordec. The resulting protocols were scored for consensus, by an 
incerencient rater, with a category to be retainec if at least 50 per cent of the subjects listed it. The 50 per cent inclusion level was chosen to be consistent with the "fuzzy" nature of categories found in both object and person categorization (Cantor,1978; Rosch,1976).

\section{Results}

The results of the protocol analysis indicated that approximately one-thirc of the subjects listed only traits (e.g., emotional, assertive, etc.), one-thirc listed types (e.g., soap-opera sals, feminists, etc.) while a further one-third listed both traits and types (See Appendix I, Tabie 1). A chi square contingency analysis incicatec that there were no sex differences in the type of category employed $\left(x^{2}=2.23, a f=2\right.$, N.S., See Appendix I, Table 1$)$. The listing of traits and.traits/types was not surprising, considering the deliberately ambiguous nature of the instructional set. Unfortunately, providing such structure Would have artificially channeled subjects' responses. subjects who listed only traits were therefore excluad from further analyses.

Consensus scoring of the remaining 65 per cent (n =131) indicated that subjects listed an average of 8.10 attributes anc 4.89 types. There were no sex differences evident in either the rumber of attributes or tyoes that subjects generated (See Appendix I, Tables 2 anc 3) although there was consicierable incivicual variation, particularly in the number of attritutes listed as compared to the number 
of types, as indicated by the large standarc deviaticns for the former.

The results of the consensus scoring are presented in Table 1, which shows that five categories met the 50 per cent inclusion criterion; they were housewife, career woman, sex object, female athlete and women's libber (All categories listed by subjects are presented in Appendix I, Table 4). A number of terms that were interpreted as synonymous with these categories and therefore included in the frequency analysis are also shown in Table 1.

The first three categories of houserife, career woman and sex object were by fax the most frequent terms used to cescribe these roles. However, choice of the last two role names, female athlete and women's libber, was more subjective, since other synonyms were used almost as frequently and these two categories barely met the 50 per cent inclusion criterion. As such, they are probably not as strong nor as clearly defined as the other three.

The categories did, however, agree quite well with those generated by the Clifton et al(1976) study. In fact, with the exception of the women's libber category, they are icientical. Thus, there is corroborative evidence for the validity of four of the five roles. 
Table 1. Categories of women that met the 50 per cent listing criterion.

Category

Synonyms Included

Per Cent Listing

Housewives

Eomemakers

65

Traditional women who

stay home

Domestic women

Career women Professional womer

60

Career-oriented women

Executive-types

Sex Objects

Sexy women

57

Seductive women

Glamour girls

Dumb blonde types

Teasers

Nymphs

Women's Libbers Women's rights activists

50

Liberated women

Women protestors

Feninists

Female Athletes sporty types

Jockettes

Female jocs

Sportswomen 
Stuảy 2. Construction of stereotypic sub-categories

The next phase of constructing stereotypic categories attempted to define subordinate categories subsumed by the roles of housewife, career woman, sex object, female athlete and women's libber. That is, would people identify still more specific categories by subdividing these roles? Essentially the same design as in Study 1 was employed to answer this question.

Method

\section{Subjects}

Subjects were 87 college freshmen, 41 males and 46 females, rancomly selected from the same introductory psychology course pool as described previously.

\section{Procedure}

Subjects were tested in class groups of approximately 30 each. The procedure was the same as that described in Study 1. Subjects responded to the following statement:

" List as many different types of the following categories of women as you can (i.e., can you think of different kinds of career women? housewives? women athletes? sex objects? Women's libbers? List them below.)" 
The resultirg protocols were scored for consensus by an independent rater to deterinine the number of categories that at least 50 per cert of subjects listed.

\section{Results}

There was a significant aifference in the rumber of subjects who categorized the five female roles on the basis of types (e.g., cook-cleaner, business woman,etc.), traits (e.g., nosey, beautiful, etc.) or both $\left(x^{2}=74.36\right.$, df=12, P(.01), in contrast with the previous task for women. As can be seen in Table 2 , the vast majority of eubjects classifiec the roles on the basis of types. This was an apparently easier task than listing types for women. probably because the roles of housewife, etc. were less abstract andinstances of them could be nore readily imagineà.

Table 2. Number cf subjects who classifiec 5 temale roles on the basis of types, traits or both.

Role

Classification category

Tota 1

Types Traits Both No resp.

Career homan

79

2

6

Housewife

64

11

11

I

87

Female Athlete

71

7

5

3

87

Sex object

66

11

7

3

87

romen's Litber

41

19

9

18 
It is also interesting to rote that the libber category had a much greater number of no responcients than the other categories. Subjects had greater difficulty subdividing this role, a point evidenced by later studies.

As in the previous task for women, no sex differences were evident (See Appendix II, Table 1).

The total and mean number of subcategory types listed for each of the five female roles are presented in Table 3 (See also Appendix II, Table 2 for this analysis by sex).

Table 3. Total number and mean number of types listed for 5 female roles.

\begin{tabular}{lcccc}
\hline Role & Total No. & $\begin{array}{c}\text { Mean No. } \\
(\mathrm{X})\end{array}$ & S.D. & N(SS) \\
\hline Career Woman & 589 & 6.77 & 4.46 & 87 \\
Eousewife & 215 & 2.65 & 1.22 & 81 \\
Female Athlete & 368 & 6.49 & 3.38 & 82 \\
Sex object & 214 & 2.64 & 1.54 & 81 \\
Women's Libber & 143 & 2.13 & 1.15 & 67 \\
\hline
\end{tabular}

Analysis of variance (subjects nested within category type $x$ sex) indicated a significant main effect of category type $(F=39.085, a f=4, P<.00 I)$. Neither sex $(F=2.397, d f=1$, 388 , N.S.) nor the sex by category interaction ( $F=1.426$, df $=1,388$, N.S.) were significant. Wultiple comparisons of 
the type main effect using the scheffé procecure (Winer,1971) indicated that significantly more types were listed for the career woman $(X=6.77)$ than for any other role and that significantly more types were listed for female athlete $(X=4.49)$ than for housewife $(X=2.65)$, sex object $(\mathrm{X}=2.64)$ and women's libber $(\mathrm{X}=2.13$; Scherfé critical value at $P<.05$ level $F=1.964$, df $=4.393$ ) The greater number of subtypes listed for career woman and athlete can be explained by the large number of professions and sports that subjects listed respectively. The other three roles were not amenable to such easily icientifiable subcategories.

The total number of cifferent subcategory types listed for each of the five roles is presented in Table 4.

Table 4. Total number of different subcategory types listed for 5 female roles by sex.

$\begin{array}{ll}\text { Role } & \text { Total Number Vale Female } \\ & \text { Diff. Types Listed }\end{array}$

\begin{tabular}{llll}
\hline Career Woman & 34 & 26 & 30 \\
Housewife & 15 & 10 & 12 \\
Female Athiete & 36 & 27 & 29 \\
Sex Object & 24 & 18 & 19 \\
Women's Libber & 16 & 11 & 11 \\
\hline
\end{tabular}


Again, there was greater variety in the tyoes listed for career woman and athlete than for the other three roles $\left(x^{2}=15.36\right.$, df $\left.=4, P<.01\right)$. It appears that the career woman and athelete roles are richer in both quantity and diversity of subtypes. It is also apparent from Table 4 that no sex differences occur in this trend.

The subcategories that met the 50 per cent inclusion criterion for each role are presented in Table 5.

Again, there was consicierably less agreement in the libber category, with only two subcategories meeting the 50 per cent inclusion criterion. This is consistent with the lack of agreement within the libber category itself found in Stuciy 1 .

There was a high level of agreement across sex for all five female roles, in the content of subcategories. All subcategories listed by each sex are presented in Appendix II, Table 3 .

The two most frequently listed subcategories for each role from Table 5 were selected as examples of subordinate categories to complete a taxonomy for further study. 
Table 5. Subcategories listed For the 5 fenale roles that met the 50 per cent inclusion criterion.

Fenale Role

Subcategories Listed

Career :ortan

Doctor

Teacher

Riurse

Lawyer

Business executive

Housewife

Cook-cleaner

Caretaker of children

nother-type

Working/non-working

Sex object

Movie star/Actress

Dlay-bor bunny

Model

Stripper

Woman sthlete

Switumer

Runner

Tennis elayer

Fomen's Licber

Mocierate comittec to equal rights

Eacical supporter of women 
Study 3. Validation of Female Sex-role Stereotype Taxonomy

The category-listirg tasks resulted in the subject-generated taxonomy depicted in Fig. 3. The fact that the categories were constructed by subjects themselves lends credence to their veridicality. It remained, however, to assess the consensual agreement for the "hierarchical" relations among categories. This was done using a carec-sorting task.

Nethoc

\section{subjects}

Subjects were 20 college freshmen, 11 females and? males, who participated as part of a class project.

\section{Procedure}

Each of the 5 midale categories and the 10 subordinate categories fiere individually typed on $3^{\prime \prime} \times 5^{\prime \prime}$ carcis. The resulting 15 card deck was randomiy orderec. Each subject was given the following irstructions:

\footnotetext{
"Each of these carcs refers to a female role or type. I want you to sort them into as mary different types as you feel exist in the ceck."
} 
After this initial sort, subjects were tola:

"Now, in each of the piles you have, see if there is one type/role that is more general than the others, that could subsume the others. If so, place it on top."

In this way, subjects should create a 2-level taxonomy only if they perceived such a relationship in the deck. Moreover, no constraints were claced on subjects as to the number that should be in each pile at either the midile or suborcinate levels. The card-sorts, therefore, should indicate the validity of the micdle level categories as well as the hierarchical relationship between these and the subordinate categories.

\section{Results}

Results of the card-sorting task provided strong validation for the taxonomy created in stucies 1 anc 2 . A.l1 subjects sorted the card deck into the appropriate five clusters representing the five midale level roles. Considering that subjects were not given instructions as to the number or type of categories they should have, as well as the fact that one might expect consicierable overlap anong female roles given the "fuzzy", overlapping nature of categories, this was impressive support for the distinctiveness of the dimensions reflected by the five midale level roles.

Noreover, 15 of the 20 subjects sorted all categories 
accoring to the taxononic structure presented in Fig. 3 . Of the five subjects who dic not, one female and one male included movie star uncer the career woman category, two females and one male sorted the libber category incorrectly, placing either the moderate or the radical at the midile level. The former response reflects the overlap menticned previously while the latter is consistent with the difficulty subjects haci with the libber role. 


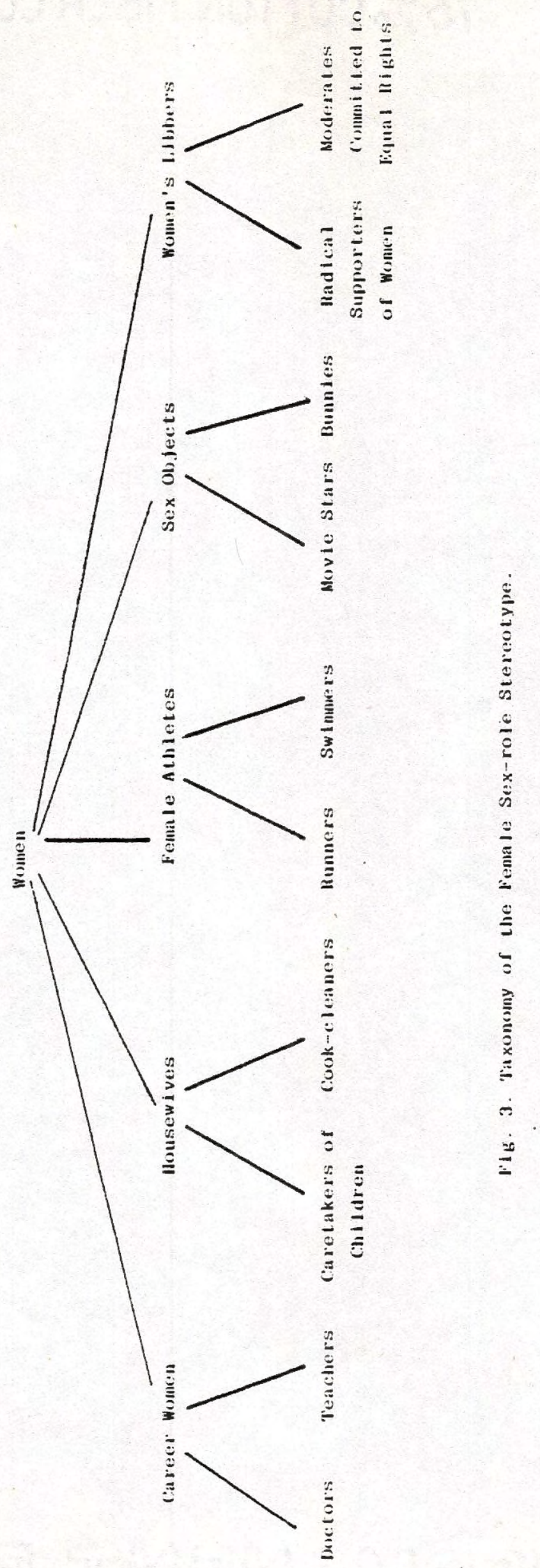


Study 4. The Structure and Content of Stereotypic Categories

Given the strong empirical support for the taxonomic structure of the female stereotype, one of the main foci of the research could now be adiressed. The present study was designed to examine the content and relations among stereotypic categories and to establish any correspondence with object and person prototypic categories. An attribute listing task was employed to provide these comparisons.

\author{
Method
}

\title{
Subjects
}

Subjects were 570 college freshmen, 308 females anc 262 males, who were tested in class groups of approximately 35. Classes were randomly selected and subjects participated as part of the course experience but were free to opt out if they wished.

\section{Procedure}

The testing procedure was essentially the same as in Study 1. Each subject was asked to responc to the following statement, distributed to each of them:

"List all the attributes/behaviours that you think are common to and characteristic of housewives (libbers, athletes, etc.)." 
All categories within the stereotyre taxonony were testec and each subject responajed to only one category, which was ranciomly assigned. Mpproximately 35 subjects responded to each category.

The resulting attribute lists were scorec for consensus, with attributes being retained that at least two subjects 1 isted. As a final refining stage, 20 subjects (10 males and 10 females), who were gaid for their participation, anä were from the sare subject pool, reted the percentage of members of the category for which each attribute would be true. Each subject rated all categories in randomized orcier. Final attribute lists, consisting of attributes that had a mean rating of at least 50 per cent across judges, were then conoileci icr each category.

\section{EESLILS}

The initial attrisus istss, consting of those that at least two subjects listed, were exanirec to cetermine if any sex differences occlired in the descriptions of the various roles. No differences were found in the rurber of attributes listed (female $x=4.6 \varepsilon ;$ male $x=4.71$ ) ror in the content cf the attributes, essentially similar attributes being listed by males and females. There was also no Cifference ir the overell proportion of negative ettributes assigned to roles, ar average of 17 per cent regative attricutes being assigned by each sex. The mall percentage 
of negative attributes is consistent with other research which shows that people clescribe others overwhelmingly in terms of positive traits (Osgood, Suci \& Tannenbaum, 1957), especially under a free-response format (Brannon,1978).

Inspection of the percentage of negative attributes assigned by males and females to each role category also revealed very similar results. There were only three role categories on which the sexes appeared to ciffer in this respect. They were housewife, women's libber and play-boy bunny. Females were much more negative (33 per cent negative responses) than males ( 13 per cent) about the housewife role ( $x^{2}$ test of proportions $\left.=5.95, d f=1, P<.01\right)$. The opposite was true for libbers, with men being more negative ( 48 per cent) than women ( 18 per cent) ( $x^{2}$ test of proportions $=9.90, d f=1, P(.01)$. These differences probably reflect the resentment of many women toward the traditional roles and society's prevailing sanctions against untraditional roles such as that portrayed by libbers. Similarly, women's more negative descriptions of bunny ( 45 per cent) as compared to men ( 26 per cent) probably underscore these attitudes $\left(\mathrm{x}^{2}\right.$ test of proportions $=6.33$, $\mathrm{df}=1, \mathrm{P}(.01)$.

Overall, the dearth of sex differences is consistent with the previous studies in this series. Moreover, the differences noted above disappear in the percentage rating task, where male-female responses are remarkably similar. Attribute lists and their associated mean percentage ratings as rated by each sex and overall are presented in 
Appendix III, Tables 1 to 16.

Table 6 presents the number of attributes listec for each category. There were no significant differences in the number of attributes listed for either the middle level categories $\left(x^{2}=3.38, d f=4, N . S.\right)$ or for the subordinate level categories $\left(X^{2}=3.90, d f=9\right.$, N.S. $)$. Fig. 4 presents the average number of attributes at each level of the sex-role taxonomy. The middle level value is the mean over the five midile level categories and the suborinate level value is the mean over the 10 subordinate categories. The number of attributes across levels of abstraction dic not ciffer significantly $\left(X^{2}=1.53\right.$, N.S. $)$. Fig. 5 presents the average number of attributes for each of the five midale roles and their associated subordinate categories. Again, the apparent increases in number of attributes from lower to middle level categories were not sigificant for any role. In contrast, Cantor and Mischel (1979) reported a decrease in the number of attributes with increasing levels of abstraction for person prototypes.

To examine possible differences in the nature of the information gained at the various levels of inclusiveness, a content analysis of the attribute lists was performed. Attribute lists were categorized according to whether they referrec to trait/dispositions, physical appearance, socioeconomic status or behaviours. The results of this classification are presented in Table 7. This analysis explicates the difference between Cantor and Mischel's(1979) data and the present study with regarc to the number of 
Table 6. Number of attributes listed for each role category.

Role No. Attributes Level Vean

Women

35

Career roman

34

Housewife

31

Female Athlete

25

28.6

Sex object

31

Women's Litber

22

Cook-cleaner

Caretaker of chilären

28

Radical supporter

20

Hoderate comitted

24

Swimmer

28

25.7

Runner

26

Doctor

25

Teacher

22

Bunny

29

Movie star 


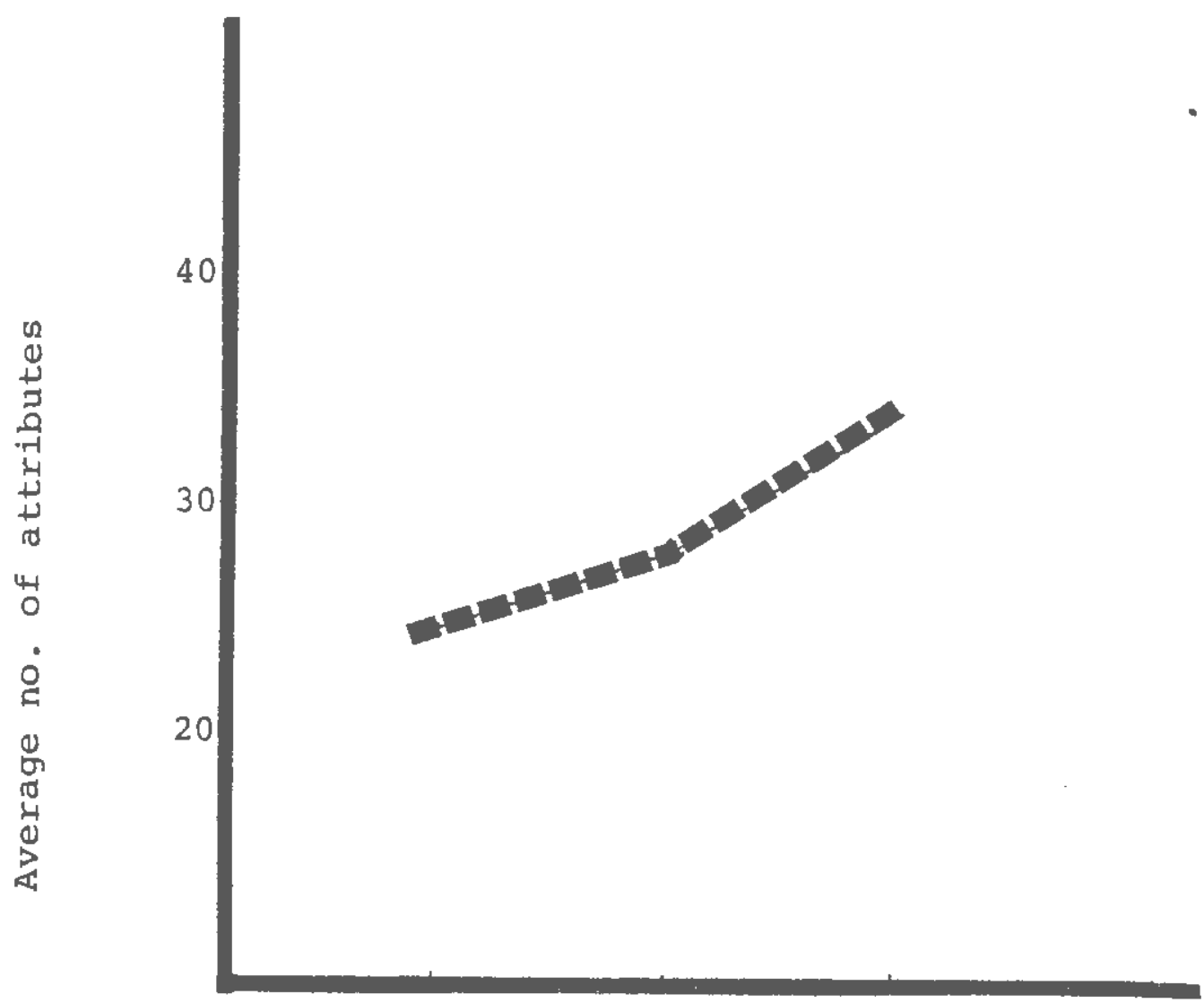

Subord. Middle super.

Level of Abstraction

Fig. 4 Average number of attributes at each level of abstraction of the female sexrole taxonomy. 


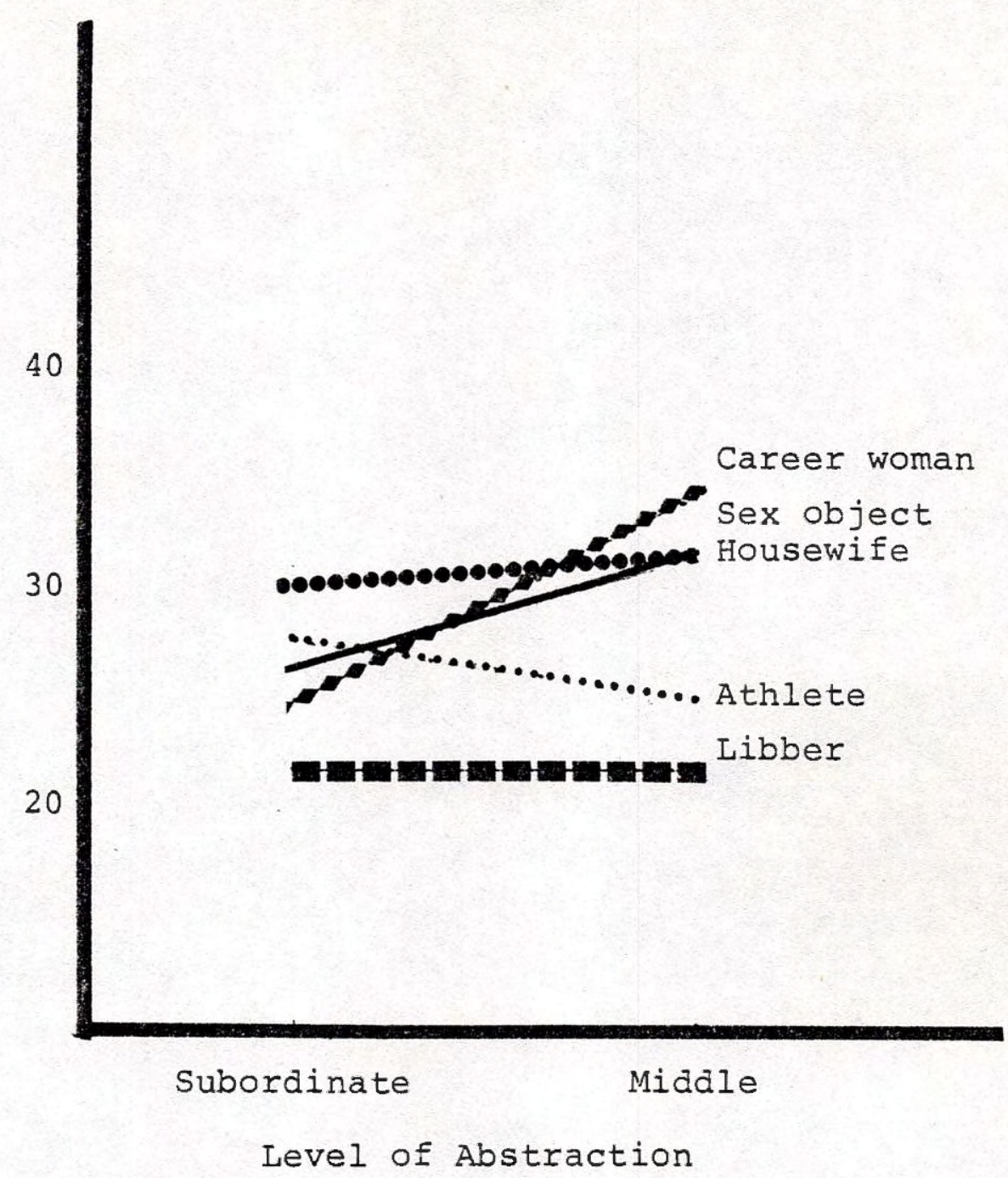

Fig. 5 Average number of attributes at each abstraction level for each of the midale level categories and their associated subordinate roles. 
attributes at different ievels of abstracticn. It is evident that only one attribute category, i.e.,

trait/aispositions, variea in the opposite direction to that reported by Cantor and Mischel(1979). Indeed, given the abstract nature of trait/dispositions, it coes not seem unreasonable that they should increase with more abstract role levels. That is, as one moves from specific roles, such as bunny to more inclusive, abstract roles such as sex object, one might expect the number of abstract trait dispositions to increase. The number of concrete, vivid attributes referring to physical appearance, behaviours and socic-economic status decreased with increasing levels of abstraction, which is the same pattern reportec by Cantor and Mischel(1979) for person prototypes.

Table 7 . Mean number and percentage of attributes of different types at each level of abstraction*.

Attribute Type

Level of Abstraction Superordinate Midile Subordinate

Trait dispositions

Physical appearance

SES

Behavicur
$30(85.7)$

$1(2.9)$

$0(0.0)$

$4(11.4)$
$21.8(76)$

$2.8(9.8)$

$.8(2.8)$

$3.2(11.2)$
$16.7(64.9)$

$2.7(10.5)$

$1.0(3.9)$

$5.3(20.5)$ 
Relatively speaking, then, these data provicie further support for the interpretation of higher level stperorcinate categories as being rore abstract in rature and lcwer level categories as being more concrete and specific in cortent. At the same time, this analysis provicies evidence for the correspondence of stereotypes and persor frototypes.

Category distinctiveness was exanined by corputing the overlap of attributes across the five midale level categories, acrcss the 10 suborcinate level catesories, and between each suborcinate pair (e.g., novie star \& bunny). An attritute was colnted as shared if it occurred in any other category at the same level of abstraction. io attribute occurred in all categories at either the micile or suborcinate levels.

Table 8 presents the number of shared and distinctive attributes across mi male and suborcinate levels of abstraction. These data are guite consistent with those of Cantor and Mischel(1979) ana Fosch(1976). Midale level categories have only half as many shared attributes $(X=8.4)$ as subordinate level categories $(x=16.0)$ and almost twice as many cistinctive attributes $(K=15.4$ \& 9.3 respectively). The midale level categories, therefore, do seem to maximize category distinctiveness anä relative richness, since they also have at least as many attributes as subordinate categories. Horeover, the middle level categories represent the intersection of general abstract attributes ard concrete, specific attributes, exhibitinc nore abstract trait ajspositions than the suborcinate level anc more 
Table 8. Number of shared and distinctive attributes across middle and suborcinate categories.

Category No.Shared No. Distinctive No.Shared in

Subcat.Pairs

\begin{tabular}{|c|c|c|c|}
\hline Housewife & 4 & 27 & \\
\hline Athlete & 10 & 15 & \\
\hline Career Woman & 13 & 21 & \\
\hline Sex object & 7 & 24 & \\
\hline Women's Libber & 8 & 14 & \\
\hline Caretaker & 17 & 11 & 12 \\
\hline Cook-cleaner & 15 & 16 & \\
\hline Runner & 21 & 5 & 16 \\
\hline Swimner & 19 & 8 & \\
\hline Teacher & 19 & 6 & 8 \\
\hline Doctor & 15 & 7 & \\
\hline Movie star & 15 & 9 & 10 \\
\hline Eunny & 14 & 15 & \\
\hline Moderate & 11 & 11 & 11 \\
\hline Radical & 14 & 5 & \\
\hline
\end{tabular}


concrete attributes(such as those that refer to physical appearance) than the superordinate level.

Tables 9 and 10 show the attributes that are shared across categories for the midile and subordinate levels respectively. It is evident from Table 9 that the majority of shared attributes occurred among the roles of athlete, career woman and women's libber. Housewife and sex object share very few attributes with other roles and are most cistinct.

Table 9. Shared attributes across midile level stereotypic categories of women

Attribute

Female Category

Housewife Athlete Career Sex Libber woman object

\begin{tabular}{|c|c|c|c|c|c|}
\hline Ambitious & & $\mathrm{X}$ & $\mathrm{X}$ & & \\
\hline Agressive & & $X$ & & $\mathrm{X}$ & $x$ \\
\hline Believe in equal. & & & $x$ & & $x$ \\
\hline Confident & & & $\mathrm{X}$ & $x$ & $\mathrm{X}$ \\
\hline Determined & $\mathrm{X}$ & $\mathrm{X}$ & $\mathrm{X}$ & & $\mathrm{X}$ \\
\hline Energetic & & $\mathrm{X}$ & $x$ & & $\mathrm{X}$ \\
\hline Pro equal rights & & $x$ & & & $X$ \\
\hline Earöworking & $x$ & $\ddot{x}$ & $X$ & & \\
\hline Intelligent & & X & $\mathrm{X}$ & $\mathrm{X}$ & Y. \\
\hline Liberal-minded & & & & $X$ & $x$ \\
\hline Sense of homour & X & $\mathrm{X}$ & & & \\
\hline Outgoing & & $\mathrm{X}$ & $x$ & $\mathrm{x}$ & \\
\hline Responsible & $\mathrm{x}$ & & $x$ & & \\
\hline Strong-minded & & & $\mathrm{X}$ & & $\mathrm{x}$ \\
\hline Sophisticated & & & $x$ & $\mathrm{X}$ & \\
\hline Tell-dressed & & & $y$ & $X$ & \\
\hline
\end{tabular}


Table 10. Shared attributes across stereotypic sub-categories of women

Attribute

Doc Tea Pun Swi Nod Raci Car Cok Str Bun

self controlled

intelligent

cedicated

har cworking

independent

efficient

goal-oriented

determined

competitive

disciplined

ankitious

liberated

healthy

strong

tall

short hair

muscular

eat properly

don't crink/smoke

in other activities

agressive

outspoken

want equality/ pro

equal rights

opposec male/

female roles

liberal-minded

have careers

loving

caring

kind

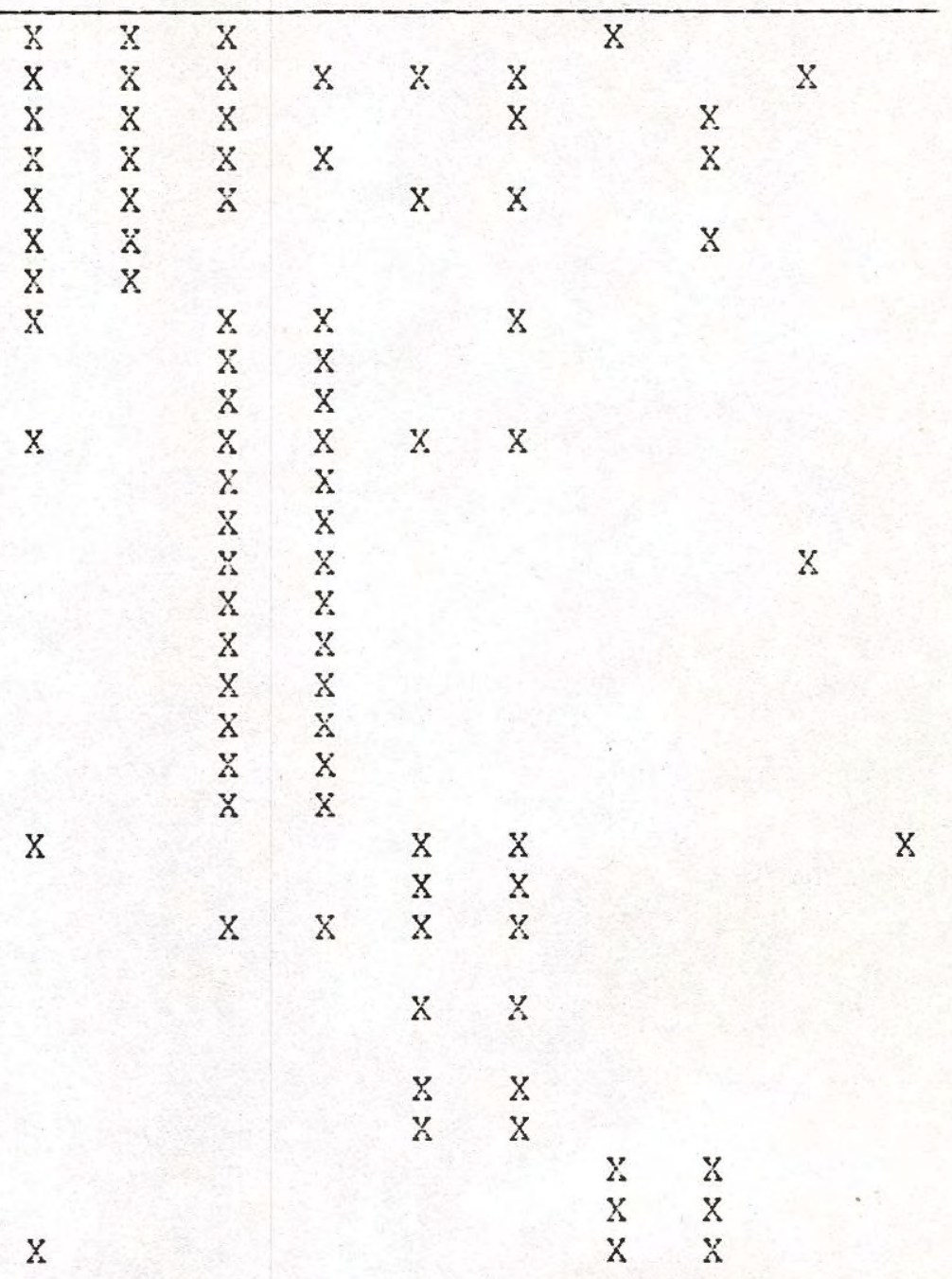

LEGEND: Doc-Doctor, Tea-Teacher, Run-Runner, Swi-Swimmer, Mod-Moderate, Rad-Radical, Car-Caretaker, Cok-Cook, Str-Movie Star, Bun-Bunny 
Table 10. (cont'd) Sharec attributes acrcss stereotypic sub-categories of women

Attribute Doc Tea Run Swi hod Rad Car Cok str bun

\begin{tabular}{|c|c|c|c|c|c|c|c|c|c|}
\hline \multirow{2}{*}{\multicolumn{2}{|c|}{ patient }} & $\mathrm{X}$ & & & & $x$ & $Y$ & & \\
\hline \multirow{2}{*}{\multicolumn{2}{|c|}{$\begin{array}{l}\text { responsible } \\
\text { helpful }\end{array}$}} & $x$ & & & & $x$ & $\mathrm{x}$ & & \\
\hline & & $\mathrm{x}$ & & & & $x$ & $x$ & & \\
\hline \multicolumn{2}{|l|}{ tolerant } & $\mathrm{x}$ & & & & $\mathrm{X}$ & $\mathrm{x}$ & & \\
\hline \multicolumn{2}{|l|}{ careful } & & & & & $x$ & $\mathrm{x}$ & & \\
\hline \multicolumn{2}{|l|}{ friendly } & $\mathrm{x}$ & & & & $\mathrm{X}$ & $x$ & & $\mathrm{x}$ \\
\hline \multicolumn{2}{|l|}{ Unselfish } & & & & & $\mathrm{X}$ & $\mathrm{x}$ & & \\
\hline \multicolumn{2}{|l|}{ depencent } & & & & & $x$ & $\mathrm{x}$ & & \\
\hline \multicolumn{2}{|l|}{ chíá-oriented } & & & & & $X$ & $\mathrm{x}$ & & \\
\hline outgoing & 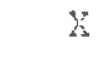 & $\mathrm{x}$ & & & $\mathrm{x}$ & & & $x$ & $X$ \\
\hline \multirow[b]{2}{*}{ good figures } & & & & & & & & $x$ & $\mathrm{x}$ \\
\hline & & & $\mathrm{x}$ & & & & & $\mathrm{x}$ & $\mathrm{X}$ \\
\hline youns & & & & & & & & $x$ & $\mathrm{x}$ \\
\hline secuctive & & & & & & & & $x$ & $x$ \\
\hline \multirow{2}{*}{$\begin{array}{l}\text { open-minded } \\
\text { conceited }\end{array}$} & & & & & & & & $x$ & $x$ \\
\hline & & & & & & & & $\ddot{x}$ & $x$ \\
\hline like attention & & & & & & & & $\mathrm{x}$ & $\underline{x}$ \\
\hline \multirow{2}{*}{$\begin{array}{l}\text { good personality } \\
\text { egotistical }\end{array}$} & & & & & & & & $\mathrm{x}$ & $x$ \\
\hline & & & & & & & & $\mathrm{x}$ & $\mathrm{x}$ \\
\hline \multirow{2}{*}{$\begin{array}{l}\text { like their work } \\
\text { active socially }\end{array}$} & $x$ & $\mathrm{x}$ & & & & & & & \\
\hline & & $\mathrm{x}$ & $\mathrm{x}$ & & & & & & \\
\hline sympathetic & & Y. & & & & $\mathrm{x}$ & & & \\
\hline \multirow{2}{*}{$\begin{array}{l}\text { under standing } \\
\text { conficent }\end{array}$} & & 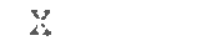 & & & & $x$ & & & \\
\hline & $\mathrm{x}$ & & $\mathrm{x}$ & $\mathrm{x}$ & $\mathrm{x}$ & & & & $X$ \\
\hline \multirow{2}{*}{$\begin{array}{l}\text { brave } \\
\text { gentle }\end{array}$} & $x$ & & & & & & & $x$ & \\
\hline & $X$ & & & & & $\mathrm{x}$ & & & \\
\hline mature & $\mathrm{x}$ & & & & & $x$ & & & \\
\hline single & $\mathrm{x}$ & & & & $x$ & & & & $x$ \\
\hline \multirow{2}{*}{$\begin{array}{l}\text { rich } \\
\text { äress well }\end{array}$} & $\mathrm{x}$ & & & & & & & $x$ & \\
\hline & & & & $x$ & & & & $x_{2}$ & \\
\hline $\begin{aligned} \text { LEGEVD: } & \text { Doc-Doct } \\
& \text { Nod-Hode } \\
& \text { Str-Movi }\end{aligned}$ & í 8 & $\begin{array}{l}\text { acher, } \\
\text { Racical } \\
\text { n-Bunny }\end{array}$ & Pun & 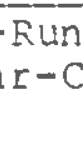 & $\begin{array}{l}\text { er, } \\
\text { reta }\end{array}$ & $\begin{array}{l}\text { Swi- } \\
\text { ker, }\end{array}$ & & $\begin{array}{l}\text { mer, } \\
\text {-Cook }\end{array}$ & $\mathrm{k}$ \\
\hline
\end{tabular}


$\mathrm{Cl}$ ifton et al(1976), using a aifferent nethocology and cifferent test items, reporteä remarkably similar fincings. They found strong evicence for distinctive stereotypes of housewife and bunny, with a thira stereotype encompassing the more non-traditicnal alternatives of career woman and atrlete. Thus, there is converging evidence that is suggestive of multi-category stereotyges of women, an issue to be further adiressec later.

Taken together, the cata reported here indicate that the micile level categories in the female sex-role taxonomy maximize the intersection of richness (number of attributes), differentiation and concreteness while recucing the cognitive load of aistinguishing too many categories. The midale level categories, like those cescribed by cantor and rischel(1979) and Rosch(1976), have much utility in person cescriptions, and, like theirs, probably function as the basic-level categories in person perception. 
Study 5. The Easic-level Category in Categorization Schemes

It has been found in categorization schemes that the most frequently used category level is the one that represents the intersection of information richness and cognitive economy. In both object (Rosch,1976) and person (Cantor \& Mischel,1979) categories, this "basic-level" category appears to be the micide level category, which provides the most information with the fevest category labels. Study 4 of the present research has also indicated this to be the case for sex-role stereotypic schemes. Furthermore, Rosch et al(1976) have empirically demonstrated that the midale level category is the one overwhelmingly used in a free-naming task in object perception, as opposec to superorcinate or subordinate names. The present study rested the hypothesis that the midale level categories of the female sex-role stereotype function as "basic-level" categories, that is, this level name woula be most frequently employed to describe an exemplar of the stereotype, rather than superordinate or subordinate names. 
Nethoci

\section{Subjects}

Subjects were 17 college freshmen, with a mean age of 18, 9 females and 8 males, who were paid to participate in the study.

\section{Procedure}

Each subject was given a booklet which containec a list of attributes selected from the attribute listing task. that described one of the micidle level roles. Of course, because of the consicerable vertical overlap between micide level roles and their subordinate pairs, these attributes would also cescribe the appropriate subordinate category. All five midile level roles were included on separate pages in ranciomized orcer. Subjects were instructed to reaci each list and then check from four alternatives provided, the term they would most freguently use to describe the type of person portrayed by the attribute list. Each set of four alternatives included the superorcinate category of woman, an appropriate subordinate category and one other midale level category besicies the correct midile level category name. A copy of the instructions and sample test booklet are inclucied as Appendix IV. 


\section{ResuIts}

Tabie 11 shows the rumber of subjects who correctir icientified the micile level category for ecch of the five Eemale roles presented.

Table 11. Number of subjects who correctly identified the midile level category across roies $(n=17)$.

Role category

Housewife Career Sex Fenale romen's

woman cbject fithlete Litber

\section{\# Correct}

Responses $\quad 14 \quad 13 \quad 15 \quad 14 \quad 9$

There were no differences among categories in the number of subjects who correctly identified the midale level category $\left(X^{2}=7.11, d f=4, \mathrm{~N} . \mathrm{s}^{2}\right)$. A significant number of subjects over all categories correctly nanec the ridale level category to descrite the attribute 1 ist $\left(x^{2}=4.76, d f=1\right.$, $\mathrm{P}<.05)$

These results support the hypothesis that the midale level categories for the Eemale sex-rcle stereotype: like those in other ferson taxonomies. function as basic-level categories, and as suck, are more likely to be enployed in person perception tasks. It is also interesting to note that most of the incorrect resoonses chose the suborcinate 
label, only one referred to another miciale level label aná only two to the superorcinate latel of noman. It appears that as a first cut of the inforsation we have about someone, the superordinate level does not convey sufficient information while the suborcinate level is too specific. The ridale level label seens to regresent the comprorise between the two. 
Study 6. Validation of the :ickile Level stereotypic Cátgeories

Studies 4 and 5 provicied strong evidence for the important function of the miçile level categories as "basic-level" categories. They represent the interuction 0. : inum information and minimum cognitive effort. They have also been shown to the the rost likely ser stereotypic labels enployed ir person cescription tasks. Study 6 bass ciesigred to frovice valiation of the five miade levei stereotypic roles, to inaicate precisely the degree of cverlap anong them and to measure the relative importance of attributes defining each role.

Itethod

\section{SLltjects}

Subjects were 563 college treshen, 320 nales and 343 females, with a mean age of 18 , who participatec in the study as part of the introductory psycholosy course experience. Subjects vere, however, free to not participate if they wished.

\section{Drocedure}

The 10 attributes for each of the five nicile level roles that received the highest rankinss in the attribute rating task pere selectea (See Table 12). Of these, five attrikutes (i.ə., anbitious, inteligent, determinec, 
Table 12. Attributes for each of the five midale level categories selected for the sex-role scale.

\begin{tabular}{|c|c|c|}
\hline Category & & ctributes \\
\hline Fenale Athlete & $\begin{array}{l}\text { Eealthy } \\
\text { Energetic } \\
\text { Co-orcinated } \\
\text { Determined } \\
\text { Anbitious }\end{array}$ & $\begin{array}{l}\text { Sports-oriented } \\
\text { Dedicated } \\
\text { Slin } \\
\text { Honsmoker/crinker } \\
\text { Hardworking }\end{array}$ \\
\hline Eousewife & $\begin{array}{l}\text { Loving } \\
\text { Caring } \\
\text { Tidy } \\
\text { Gentle } \\
\text { Busy }\end{array}$ & $\begin{array}{l}\text { Do housework } \\
\text { Care abour children } \\
\text { Devoted to children } \\
\text { Hardivorking } \\
\text { Peed appreciation }\end{array}$ \\
\hline Sex object & $\begin{array}{l}\text { Eeautiful } \\
\text { Seductive } \\
\text { Popular } \\
\text { Seek } \\
\text { attention } \\
\text { Dress } \\
\text { seciuctively }\end{array}$ & $\begin{array}{l}\text { Gocd figure } \\
\text { Fashion corscious } \\
\text { Attentive to appearan } \\
\text { Socialize more vith m } \\
\text { Wear heavy makeup }\end{array}$ \\
\hline Tomen's Libber & $\begin{array}{l}\text { Aggressive } \\
\text { Indepencient } \\
\text { Confidient } \\
\text { Acventurous } \\
\text { Determined } \\
\text { Defensive }\end{array}$ & $\begin{array}{l}\text { Believe in equality } \\
\text { Want responsibility } \\
\text { Strong-mincied } \\
\text { rnowlecgeable } \\
\text { Intelligent }\end{array}$ \\
\hline Career Tioman & $\begin{array}{l}\text { Batlire } \\
\text { Ambitious } \\
\text { Competent } \\
\text { Liberated } \\
\text { Intelligent } \\
\text { Determined }\end{array}$ & $\begin{array}{l}\text { Goal-oriented } \\
\text { Coll ege-ecucated } \\
\text { Believe in equality } \\
\text { Eesponsible } \\
\text { Eardivorking }\end{array}$ \\
\hline
\end{tabular}


harc-working and kelieve in ectuality) occurrec in more than one category, resulting in a list of 45 attributes. These were placed on a seven point Likert scale fror very atypical to very typical and randomly orcered.

Subjects were tested in class groups of approximately 35 and three classes each were randomly assigned to rate one of housewives, women's libbers, female athletes, sex objects, career women and women. The instructions and test scale are included in Appendix $V$.

\section{Results}

The 663 responses to the 45 Likert scales were submitted to a principal- components analysis. Using Kaiser's rule (Kaiser,1958), seven factors were extracted that had eigenvalues greater than 1.00. These factors were orthogonally rotated using the Varimax procedure, and factor loadings of .50 or greater were considered meaningful for the purposes of factor definition.

The factor matrix resulting from this analysis is presented in Appendix $v$, Table 1. The last factor in this matrix had no high loadings, the highest being .34 . Furthermore, of the 45 scales, eight did not load significantly on any factor. To achieve better structure (Earmon,1967; Child,1978), these scales were therefore dropped and the remaining 37 scales submitted to principal-components analysis using the sare criteria cescribed above. 
This analysis dic indeed yiela better structure. Six factors were extracted that had eigenvalles greater than 1.00; each scale loaciec on at least one factor; anc, with the exception of "healthy", each scale loacied on cnly one factor. Noreover, the six factors accounted for the same amount of the total variance as the first analysis, 61 per cent. This analysis was therefore taken as the final factor solution. Table 13 presents the six factors and associated factor loacings that were .50 or greater. The full factor matrix, with associated eigenvalues and communalities, is presented in Appendix $V$, Table 2.

The results of the factor analysis provide strong evidence for the distinctiveness of the profiles for career woman, sex object, housewife anc athlete. A comparison of Tables 12 and 13 shows that the attributes defining each of these profiles from the attribute listing task are essentially the same as those yielced by the factcr analysis. These results are impressive considering the overlapeing nature of categories and "fuzzy sets", which vas also reflected in the levels of shared attributes in the present research. For example, five attributes were shared by more than one profile in the top 10 attributes rated and several other attributes were shared by profiles at a lower Erecuency level. Factor analysis indicated that four of the five shared attributes (intelligent, believe in equality, determined a anbiticus) were most important in defining the career woman profile while the fifth attricute (harc-working) loaded most highly on the athlete profile. 
Table 13. High factor lcadings for rotated factor matrix of 37 scales.

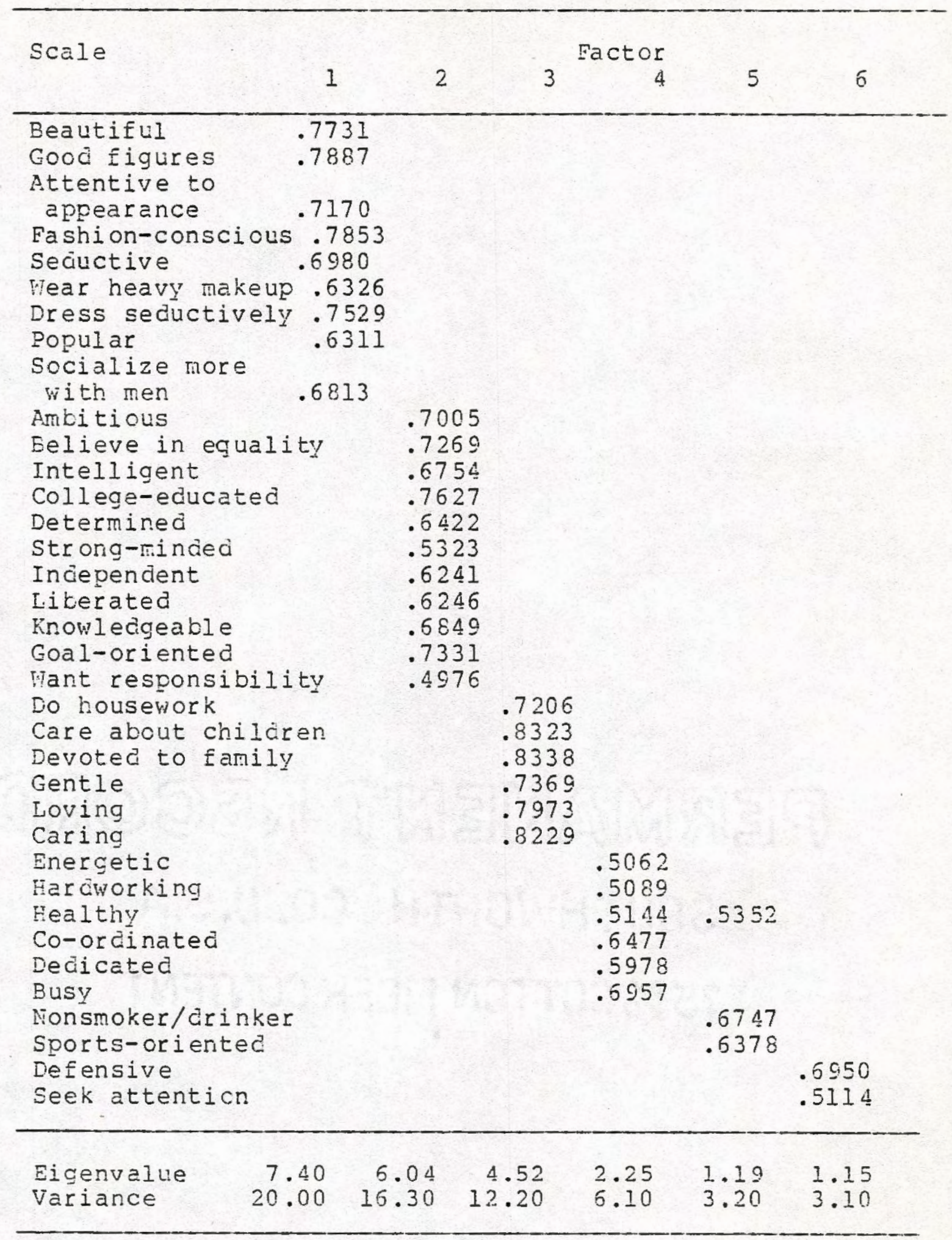


ot the other attritutes on the sex-role scale, only triree noved from their original roles to another rofile; "slin" frcr: the athlete to the sex cbject profile; "seen attention" from the sex object to the libber Frofile; and "busy" Erom the housewife to the athlete profile. It is also interesting to note that the athlete profile compises two factors. An examination of the attricutes defining these shows that the abstract attributes (factor 4) are separated fron the concrete/behavioural attributes (íactor 5 ).

Table 13 also shows that only two attributes loages on the libber Erofile. This nay be partly accounted for by the considerable initial overlap between the libber and career woman ir the rost important attributes definirg each (See pable 12). Six attributes were unigue to the libber Trofile; aggressive, aciventurous, confident, knowlecgeabie, want resporsibility and cefensive. of these, "aggressive", "confidert" and "acventurous" Gid not lcac hichly on any proíle. "Knowledgeable" and "want responsibility", along with the other attributes shared with the career wonan, loadea on the career woman profile. Cnly one of the original libber attributes, "óefensive", loacied on that proíle.

Another possible explanation for the snall number of characteristics cefining libber mey be that this role vas less wel-definech throughout these stucies. The libber role barely met the 50 per cent listirg criterion for category tyees; had the greatest number ci omissions for 1 isting 
subcategory types; had the greatest number of errors in the card-sorting task and had the fewest attributes Iisted in the attribute listing task. The factor analysis results are consistent with these findings; the libber role being the last factor extracted, accounting for the smallest amount of variance of the scale, and being the only factor not overdetermined, with only two scales defining it. It is possible, of course, that the libber role would have emerged more clearly if more of its unique attributes had been included on the sex-role scale. However, this would not have been consistent with the methods employed here, which selected attributes on the basis of frequencies, rather than their uniqueness.

Still another possible reason for the weakness of the libber role is the use of the term "libber" itself, which has consicierable negative connotations. This is evident from the loading of only negative attributes on this role while its initial positive attributes loaded on career woman. Derhaps the term "feminist" or "lntraditional", both of frequent occurrence in the category listing task, woula capture the gist of this dimension without over-emphasizing negative attributes. This possibility is supported by the fact that the "mocerate committed to equal rights" is described in more positive terms than either libber or its other subcategory of "radical supporter of women".

Finally, the factor analysis results on the libber role may simply reflect the fact that subjects perceive no uifference between career women and libbers, except on 
negative dimensions that then comprise the libber role. Clearly, these possibilities require further investigation. The overall results of the factor analysis provide strong corroborating evidence for at least four ciistinct sex-role profiles of women; career woman, housewife, sex object anci athlete.

The same factor analysis was performed separately for each sex in order to determine if males and females differed in their ratings of women's roles. These analyses yielced strikingly sinilar patterns for males and females, which were essentially the same as the overall analysis reported in Tabie 12. The analysis for females was virtually identical to the overall analysis and accounted for 63 per cent of the variance. The analysis for males, which also accounted for 63 per cent of the variance, varied only slightly from that for females. Seven factors were extracted with eigenvalues greater than 1.00. The clusters representing career woman, housewife and sex object were the same as those for the overall analysis. The female athlete profile was the same also, except for the "nonsmoker" scale which loaded with the "defensive" scale to comprise factor 6 (the litber role). In adition, a further factor (7) vas composed of only one scale, "intelligent".

The Tukey A procedure was used to compare the mean scale ratings of males anci females for all scales and no significant differences were found. The absence of significant sex differences on the sex-role scale is entirely consistent with the amazing similarity of male ard 
female responses in both the category generation and attribute listing tasks. It appears that males anci females do not ciffer substantially in their perceptions of stereotypic female roles or what attributes comprise these roles. They probably do differ, however, in their evaluation of these roles, as suggested by the only sex differences found in this research, in which the sexes differed on the number of negative attributes they assigned to a number of roles (See Study 4 ). 


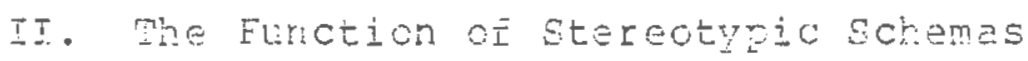

Experiment 1. Fecornition vemory Pest

It has beer cenonstrated that prototyyes funotion as cosnitive schemas in processing information about cthers. The more an inciviaual fits a prototype, the more easily informaticn about that person is categorizeci recalleci and recosnizea (Cantor \& Visciel,1979; Deujiroto,1978). Horeover, stuiy 4 of the resert research sucgests the Iuncticnal corresgondence between stereotyges anc person prototyres. Accorcingly, if stereotyes iunction as prototypic schemas, then information consistent with the stereotype shoulc be more easily recalled or recognized. Study 4 also provided strong evidence that the ricide level stereotyic categories of uomen wore the ones that Elinction as basic-level categories. in that they regresent the intersection ct maxinum information and minimlun cogritive load. Study 5 provided direct eviderce that these categcries were the most frequently usec to cegcice exenclars of the female stereotype. Since midile level categories arpear to be the basic categories for organizing stereotypic information, then information consistent bitb them should be more easily recognized. Soreover, a menory bias tovare tie stereotypic cétjgory sholid also be evicent Ecr stereotyuic corsistent information not includecin en criginal stirulus Iist. The present experimert was cesicrec. to examine these asumptions usirg a recocniticn nemory 
paracign.

\section{Eesicn}

The cesign of the recognition menory task, depicter in Fig. 5, was a 2(Erototype) $x 2$ (Instruction) : 2(Item type) repeatec neasures desigr vith the last factor repeatec.

Prototype

Condition

Item Type

\begin{tabular}{|c|c|c|c|}
\hline \multirow{3}{*}{ Central } & & Relatec* & onrelatec \\
\hline & Explicit & $n=15$ & $\mathrm{n}=15$ \\
\hline & Implicit & $n=15$ & $n=15$ \\
\hline \multirow[t]{2}{*}{ Peripheral } & Explicit & $n=15$ & $r=15$ \\
\hline & Implicit & $n=15$ & $n=15$ \\
\hline
\end{tabular}

*Sane subjects in relatect-inrelated conciticns.

Fig.5. Design of recognition memory experinent.

Two groups of subjects nere presented with a list of attritutes that describec a central exemplar of one micile level stereotyric catecorw, "caroer moman" (Central Prototype), while the other two grcups were presentec vith a list of attributes peripheral to the category (geripheral 
Prototyel. For one of the two groups given the central attribute list, the exemplar was ramed in the instructions to subjects (Explicit condition) whereas for the cther group it was not (Implicit Condition). Sinilarly, the exemplar was namec for one of the tro groups receiving the peripheral Iist, while for the other group it nas rot named.

subjects were given a recognition memory test, consisting of a list of attributes of three types (See rable I4):

1. attributes from the acquisition (is.stimulus) list

2. attributes that were not part of the accuisition list but vere conceptually relatec to the stereotypic category (Relatec Concition)

3. attributes that were not part of the acruisition list and were unrelatec to the sterectypic category (Unrelatec Condition).

It was preaicted that subjects voulc show greater recognition memory for acquisition items ove non-acquisition items; that subjects would falsely recognize more conceptually related items than unrelated items; and that this effect woula be greater for the central prototype exemplar anò under explicit instruction conditions.

\section{Subjects}

Subjects $v \in r e 60$ college freshnen, 30 males and 30 females, with a mear age of is, who participatec in the ezperiment as part of a class project. 


\section{Proceciure}

Subjects were ranciomly assigrec to cre of the experinental groups and each group was tested as a group. Subjects in the Explicit Condition were given the following instructions:

"We are going to conciuct a test of nemory. I will reac a list of attributes that coula be usec to cescribe a

Career Voman. Afterwaras, I'm going to ask you to remember as mary attributes as you can."

Instructions for the Implicit Concition vere the same except that Fictitious Character was substituted for Career Noman. The Central or Peripheral list was then reaci, at the rate of one attribute per secona.

Table I f presents the accuisition and recognition test items for the Central and Peripheral prototype exemplars. Attributes for the Central exemilar vere selected from the career woman attribute list while those For the Deripheral exemplar were rancionly selectec from the attribute lists for the remaining four micile level categories of womer (i.e., holsewife, athlete, etc., See Appendix III). 
Table 16. Summary of items used to cescrike sood and peripheral exemplars of a career woman.

Good Exemplar

ACciuisition Test Items

Recognition Test Items

believes in equality

determineci

ambitious

goal-oriented

college-eciucated

intelligent

confident

independent

strong-mincied

mature

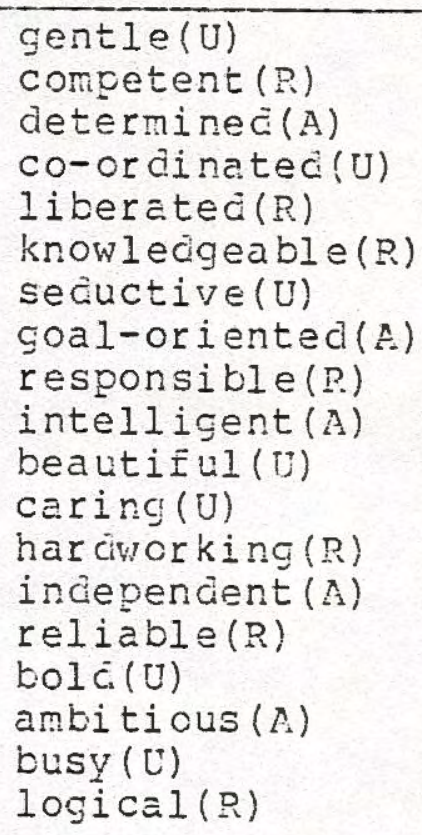

Acciuisition Test Items

Peripheral Exemplar

Recognition test Items

popular
tolerant
strong
self-satisfied
patient
concerned
tidy
Elirtacious
fashionable
slim

gentle

competent

self-satisfieci( $A$ )

co-orcinated

1 iberated

knowledgeable

secuctive

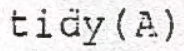

responsible

Elirtacicus (A)

beautiful

caring

har dworking

$\sin (A)$

reliable

bola

patient (A)

busy

$\log \hat{i} c a l$

A-acquisition; U-prototype unrelatec; R-prototype relatec 
The recognition memory test items included three types of attributes:

1. 5 attributes rancomly chosen from the acquisition list

2. 7 attributes randomly chosen from the remaining career woman attribute list (Relateci items)

3. 7 attributes randomly chosen from the remaining attribute lists of the cther midile level categories of women(Unrelatec items).

After the reacing of the acquisition list, subjects vere instrlicted to count aloud, backvarcis, from 1050 for two minutes ir: orcer to disrlpt immeciate short-term memory. They then completed the recognition memory test, which began with the following instructions:

" Use the scale below to indicate how certain you are that each of the following items were among those you just hearci."

1 2 3 4

certain that item was on list

maybe item was on list naybe item certain was not on item was list not on list

\section{Results}

Means and standarc deviations for the acquisition and non-acquisition items for each of the experimental groups are shown in Table 15 . 
Table 15. Ieans and Etandarc deviations of acruisition aric non-acouisition itens în treatnent grous.

Prototype concition

Itemitye

Acquisition Non-acọuisition

$\ddot{x}$ S. I.

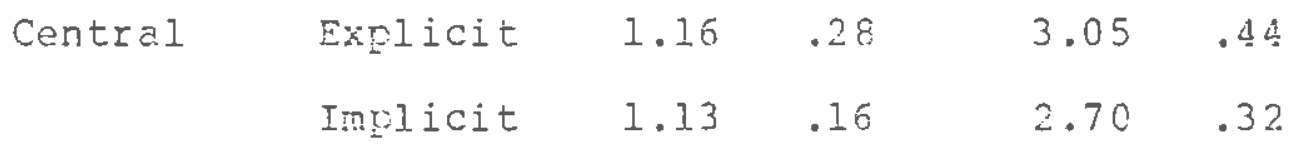

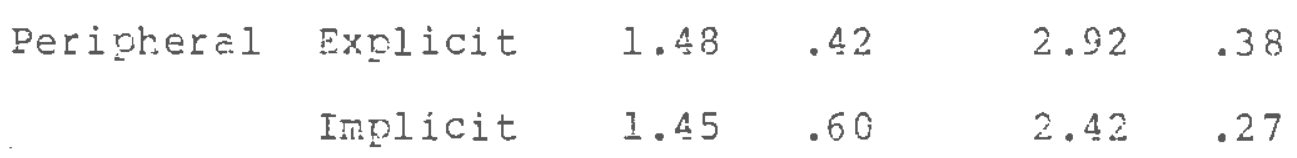

Analysis of variance (Drototype $x$ Concition $x$

Itemtye(repeatec)) of these cata is presentecin table 16.

The analysis of variance revealed the precicted effect of Item type. Subjects exhibited sreater recognition conficience for acquisition items ( $X=1.31)$ than for non-accisition items $(x=2.77)$. There vas also a sigrificant rain effect of condition on recognition conficence, suljects showing greater recognition conficerce uncer Imrlicit instructions $(2=1.93)$ than linier Explicit instrlictions $(X=2.15)$. Exarination of Table ij shors that this cifference is accounted for by 
Table 16. Anelysis of variance of eccuisition and nonacquisition memory scores across treatments.

\begin{tabular}{lllllll}
\hline Source & SS & LF NS & F & $P$ \\
\hline
\end{tabular}

\section{Between}

Nithin cells

$$
8.9178 \quad 56 \quad .1593
$$

Constant

$$
499.5143 \quad 1 \quad 499.5143
$$

Prototype

$$
\begin{array}{lllll}
.1027 & 1 & .1027 & .6447 & \text { N.S. }
\end{array}
$$

Concition

1.5075

1

3. 5075

$9.4655 \quad .01$

Prot. x Cond.

$.0407 \quad 1$

.0407

.2556 H.S.

vithin

Within cells

.1299

Itemtype $64.5773 \quad 1 \quad 64.5773 \quad 496.7860 \quad .01$

Prot. x Itemtype 2.05141

2.0510

$15.7820 \quad .01$

Conci. x Itemtype 1.1702

1

]. .1702

$9.0020 \quad .01$

Prot. $x$ Cond. x Item. $.0 \$ 07 \quad 1$

.0407 .3130 N.S. 
cifferences in the non-accuisition items. Inceed, there was also a significant interaction of Condition and Item type, which explicates this effect. Fig. 7, which ciepicts this interaction, shows quite clearly that there are no differences between Explicit-Implicit instructions for accuisition items $(\mathrm{X}=1.32 \& 1.29$ respectivelY). Nultiple comparisons using the scheffé procecure confirmec that Explicit-Implicit instructions differec only for the ron-acquisition items. Subjects were surer that they had not hear $\bar{c}$ the non-acquisition items uncer Explicit instructions than they were under Implicit instructions, which is consistent with the predictions made. Explicit instructions appear to more ciirectly activate the stereotype and hence aid memory for information about the stereotype. Thus, subjects are more certain of what they have or have not hearc.

Similarly, the Central exemplar also appears to aid information input. Fig. 8 shows a significant interaction of Prototype and Item type. Nutliple comparisons using the scheffe procedure indicated that this effect was accounted for by a significant difference between the Central versus Peripheral prototypes on the acquisition items $(x=1.15 \& 1.47$ respectively). Subjects showed greater recognition confidence for acquisition items of the Central prototype than they did for the Eeripheral prototype, which suggests that the Central prototype exemplar aids the encocing process.

The second analysis examinec recocnition ratings 


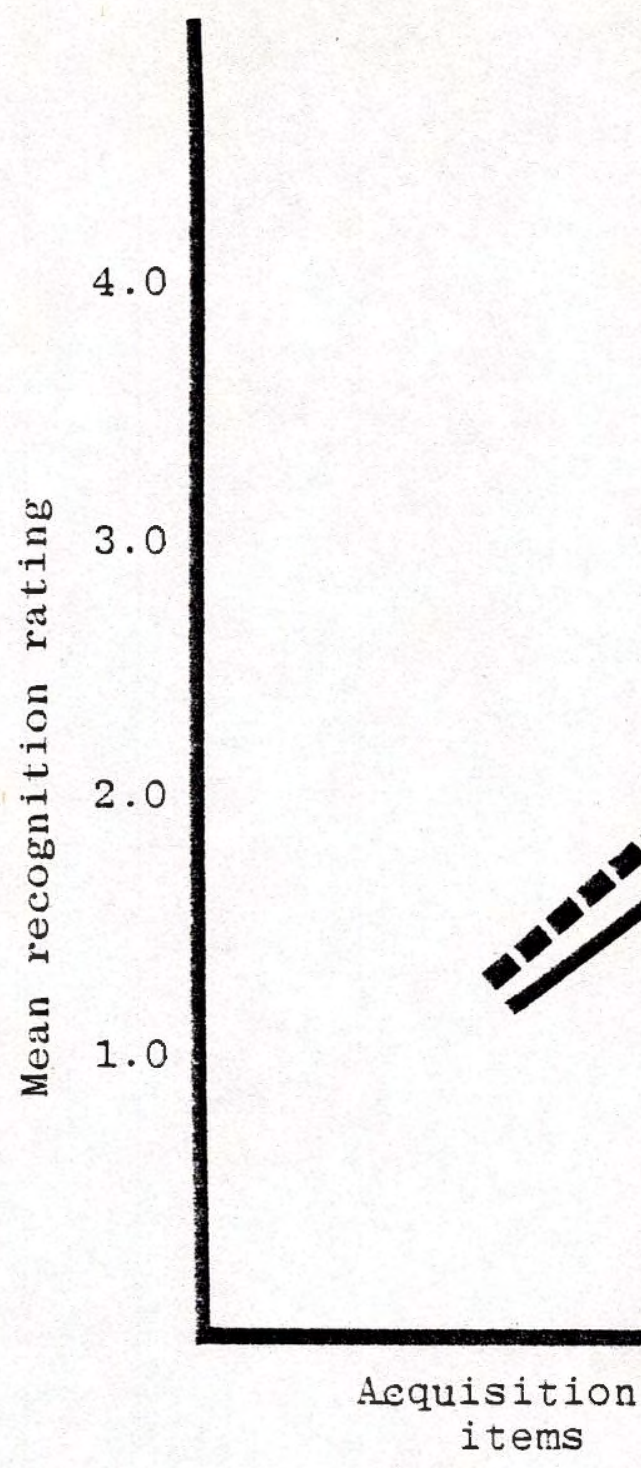

Explicit condition Implicit condition

Figure 7. Interaction of Explicit-Implicit instructions and Item type 


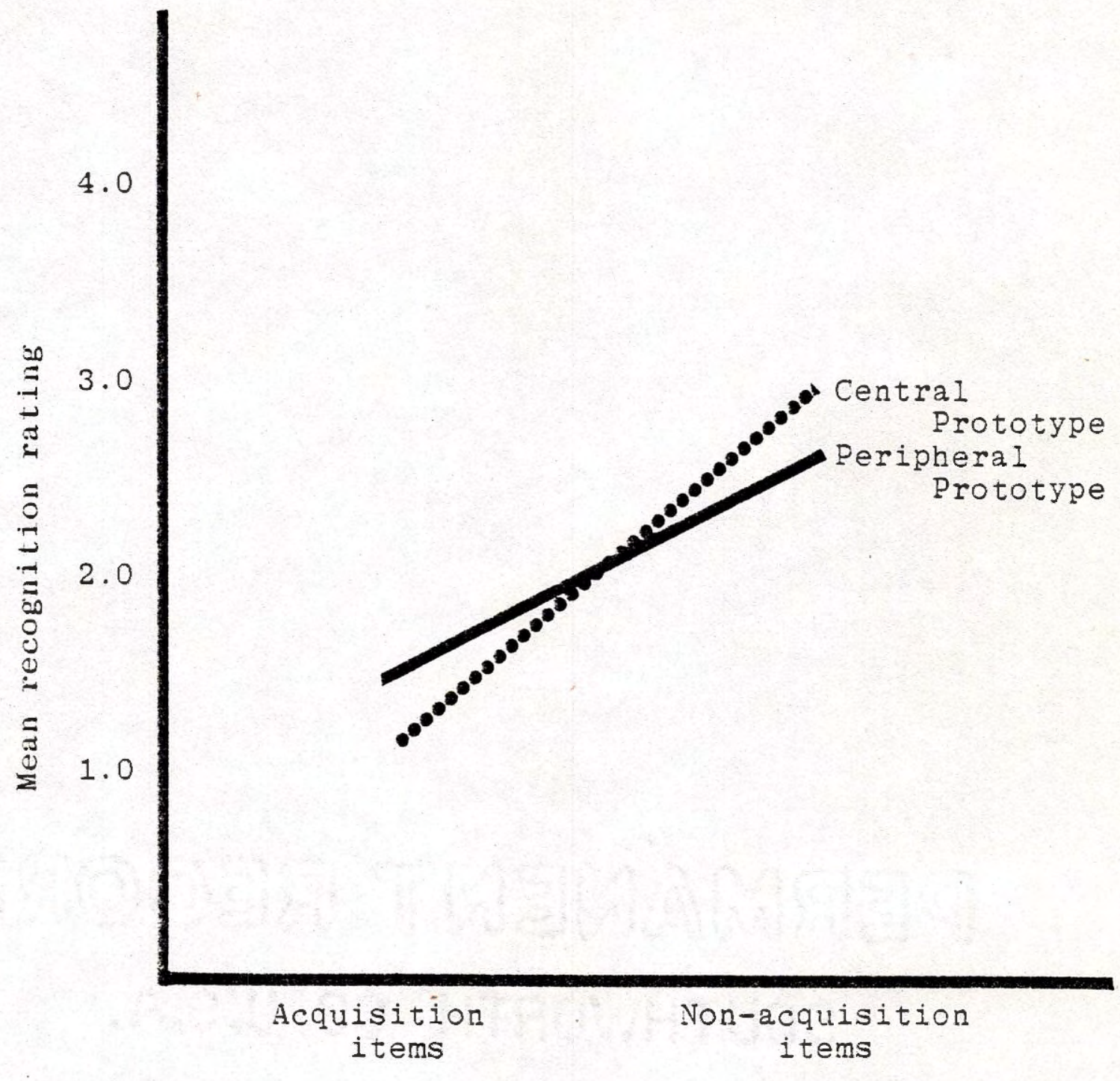

Figure 8. Interaction of Prototype and Itemtype 
of onli the ron-rresented iters. Fable 17 gresents the wearis and stenderc deviations for these itens, cividec into related are unrelatec tyres, across emperimental grours.

rable 17. Neans anc̈ standare deviations of relatec anci Lnrelatec items in the rocosnition memorv task.

Prototype Concition Itemtype

\begin{tabular}{llll} 
Felated & \multicolumn{2}{c}{ linrelated } \\
$\because$ & S.D. & $\because$ & S.I.
\end{tabular}

$\begin{array}{llllll}\text { Central } & \text { Explicit } & 2.23 & .57 & 3.74 & .28 \\ & \text { Implicit } & 1.92 & .33 & 3.47 & .51\end{array}$

\begin{tabular}{|c|c|c|c|c|c|}
\hline \multirow{2}{*}{ PeripheraI } & Explicit & 2.49 & .53 & 3.35 & .40 \\
\hline & Inplicit & 2.13 & .31 & 2.74 & \\
\hline
\end{tabular}

Analysis ö́ variance (Prototyve $x$ Concition $x$ Itemtye(repeatedi) of these data is presented in Table 18. This analysis revealec the precictea nain effect of Item type. Subjects falsely recogniaed itens relatec to the stereotyge $(r=2.19)$ to a rich greater eytent then items unrelatec to the stereotye $(x=3.33)$. There vas also a significart aEin efiect of Conditior. Sujectio extessci creater certainty tilat they had hearc the unpresented iters uncer the Irplicit concitior $(\alpha=2.56)$ 
Table 18. Analysis of variance of related and unrelated items across treatments.

Source

SS

DE

MS

F

P

Between

within cells

$13.4476 \quad 56 \quad .2401$

Constant

$913.4494 \quad 1 \quad 913.4494$

Prototype

$.7808 \quad 1$

$.78083 .2517 \quad 3.5$.

Condition

4.4544

$.4544 \quad 18.5496 \quad .01$

Prot. $x$ Cond. $\begin{array}{lllll}.2881 & .2881 & 1.1998 & \text { N.S. }\end{array}$

Hithis

Within cells

$$
\begin{array}{lll}
7.9900 \quad 56 \quad .1426
\end{array}
$$

Itemtype

38.4654

$38.4654269 .5918 \quad .001$

Prot. $x$ Itemtype

$4.8401 \quad 1$

$\begin{array}{lll}4.8401 & 33.9226 \quad .001\end{array}$

Conci. : Itemtype

$.0864 \quad 1$

.0864

.6055 1?.S.

Cond. $x$ Prot. $x$ Item

.15991

$.1599 \quad 1.1205$ N.S. 
than uncer the Explicit condition $(\ddot{x}=2.95)$. There was also a significant interaction between Erototype anci Iten type. Hultiple comparisons using the scheffe procedure indicated that there vas a significant cifference between the Central and Peripheral prototypes on the unrelated items. Fig. 9 shows that subjects were more certain that they had heard the unrelated items for the Peripheral prototype $(x=3.04)$ than for the Central prototype $(x=3.62)$. The Central prototype appears to emphasize the distinction between prototype-related material and prototype-unrelated material. This is also suggestec by the greater cifference between related-unrelated item means for the Central prototype than for the Peripheral prototype ( 1.54 and .74 respectively). However, the predictec difference between Central and Peripheral procutyes for fustbye relatect items only approachec significance $(Z<.05)$. There are several possible explanations for this failure.

The feripheral exemplar cici inciuce several attributes that were low on the career woman profile. This was, of course, expected given the cverlap among sterectypic roles and the inherently overlapping nature of "fuzzy" categories, especially at their boundaries. It may be, therefore, that the peripheral exemplar was sufficient to prime the stereotype. That is, the sterectype may be so powerful that the centrality of information about it is rot important in its activation. Alternatively, the peripheral exemplar may not 


$$
L
$$


have been sufficiently "peripheral" to the stereotype. Given the overlapping nature of categories, ranciom selection of attributes from other roles may have been an inappropriate method to construct a truly peripheral exemplar.

Thirdly, the prototype related items may simply have been easier to remember than the unrelated items and a memory ceiling effect occurred which masked possible prototype differences. This cioes not seem likely, however, in that there are no apparent cifferences in word length or frequency of usage of the related and unrelated lists. Moreover, the difference in mean recognition ratings between related and unrelated lists was twice as great for the central prototype as for the peripheral prototype (i.e., in the predicted direction).

Replication of this concition, using a more distinct stereotypic role that has virtually no communality with the other roles (e.g., housewife), and for which peripheral exemplars can be clearly constructed, should be done. The centrality and memorability of exemplar lists should be pretested and several gradations of centrality employed (e.g., central, moderate, peripheral). These procedures shoulc explicate prototype centrality effects.

Overall, the results of this study corroborate those reported by Cantor and Michel(1977) for extravert/introvert prototypes. Both studies found significantly greater recognition corfidence for 
acquisition versus non-acguisition items and for prototype related versus unrelated items. Pecognition conficence was also significantly greater for unrelatec items for the Peripheral(control) prototype as opposed to the Central prototype.

Cantor and hischel(1977) diä not find any differences between explicit-implicit instructions whereas the present study found several. Subjects were surer that they had heard both the ron-presented items and items unrelated to the prototype under the Implicit condition as compared to the Explicit cordition. It appears that the Explicit conaition more directly primes the stereotypic category, making it more available for organizing input. The Implicit condition, on the other hand, requires subjects to abstract the stereotype from the attribute list, a more difficult task. The difference between these results and Cantor and Mischel's(1977) Eailure to find any differences is probably acounted for by the different methods employed by the two stucies to prime the prototypic categories. Cantor and Mischel(1977) embecided the prototyce names within their attribute lists whereas in the present study, the prototypic category was named at the beginning of the task, before the attribute list was presented. Hence, the category was more evident in the present study. The priming of the stereotypic category prior to stimulus presentation also probably accounts for the Explicit condition aidirg organization of input 
(acquisition items).

Corsiciering that the two stidies employed different procedures and different prototypes, the corresponcence and corsistency of restits constitute converging evidence for the mediational function of prototypes as organizational schemata that aid encocing and memory of person information. These results also indicate that stereotypes function as prototypic scherata.

It should also be noted that the cata of the present study were examined for sex differences anc none were found, a consistent result throughout this research. 
Experiment 2. Organization in Free Recall

It is conventional to study order of output in free recall memory data to draw conclusions about the structure of information in long term memory (Friendly, 1977;

Hamilton, Katz \& Leirer,1980; Hastie,I980; Sternberg \& Tulving,1977). In the typical study concernea with clustering in free recall, subjects are presented with a stimulus list comprised of items representing clearly specifiable categories (e.g., birä-robin, canary, sparrow). Several instances of each category are presented in scrambled order and the subject's free recall list examined to determine the extent to which the items are grouped into the "a priori" categories. To the extent that such grouping is evident, the subject has organized the stimulus items according to the cognitive schemas that were salient to him.

Thus, analysis of clustering in free recall protocols provides a test of the organizational function of stereotypic schemas. If stereotypic categories function as organizing schemas in memory, then stereotypic attributes should show a tendency to be grouped together in memory.

Method

\section{Subjects}

Subjects were 20 college freshmen, 10 males anc 10 females, age 18, who participated in the study as part of the introductory psychology course. 


\section{Procedure}

Subjects were assembled in a classroon arc tested as a group. They were given the followirg instructions: "we are going to conduct a test of memory. I will read a list of words and afterwards I will ask you to remember as many as you can"

The stimulus list, presented in Table 19, consisted of five items ranciomly selected from each of the attribute lists for career woman, housewife, athlete and sex object. Libber was not included because of its considerable overlap with career woman in central attributes.

Table 19. Stimulus items used in the free recall task.

$\begin{array}{ll}\text { determined } & \text { sports-oriented } \\ \text { popular } & \text { college-educated } \\ \text { ambitious } & \text { loving } \\ \text { caring } & \text { healthy } \\ \text { nonsmoker } & \text { co-orcinated } \\ \text { intelligent } & \text { fashion-conscious } \\ \text { beautiful } & \text { maternal } \\ \text { energetic } & \text { seductive } \\ \text { liberated } & \text { tidy } \\ \text { gentle } & \text { Elirtacious }\end{array}$


The items on the stimuIus list were randomly orderec anc read at the rate of one per seconc. Subjects then counted backwarcs aloud for two minutes to cisrupt iminediate short term memory. They then wrote as many of the items as they could recall. To reduce the possible confounding effects of memory processes on category clustering, that is, to ensure that demonstration of clustering was not interfered with by difficulties in rementering the items, the procecure vas repeated to ottain a secona recall meâsure.

\section{Results}

The Bousfield(1966) incex was chosen to measure clustering in the free recall protocols. Although there are a number of such measures, the Bousfield incex appears to be as sensitive as any of those in current use (Sternberg \& Tulving, 1977). Moreover, it is desigred to measure exactly the kind of categorical organization of theoretical interest here. The inajex measures the co-occurrence of pre-determined category items compared to expected chance levels of co-occurrence based on the number of categories and number of items recalled.

On the first recall, the Bousfield index yielded a $x^{2}$ of $3.78(\mathrm{df}=1)$ which was just short of significance at an alpha level of $.05\left(x^{2}=3.84\right)$. The mean number of items recalled was 9.3. On the second recall, the Bousfield measure was significant $\left(x^{2}=4.50, d f=1\right)$, inaicating that items clustered beyond chance levels according to the four 
stereotypic role categories. The mean number of items recallea, 13.9, was also consicerably higher than that on the first recall, indicating that menory difficulties nay have confounded organizational tenderies on the first reca 11.

A significant amount of clustering according to stereotypic categories is quite impressive in that this technique reguires very distinct categories with very little, if any, overlap among categories. Yet in this research, the attribute listing task (Study 4 ) and the Eactor analysis (study 6) clearly showed that there was overlap among stereotypic categories.

The clustering by stereotypic categories found here was undoubtecily augmented by the fact that all category attributes loaded highly on their respective profiles (i.e., were central). Cantor and Mischel(1979) found that central category attributes were most important in defining prototypic categories on the basis of scant eviaence. The data here also suggest that central attributes are the focus of category definition, even when the categories show considerable overlap in peripheral attributes. Whether or not this woulc be the case if peripheral attributes were also actually presented remains to be testeá. It would be of considerable interest to exanine the organizational cynamics of central and peripheral attributes as well as the role of context irformation in stereotypic categories. The paradigm described here ray be a useful starting point for such research. 
Discussion

1. The Female Sex-role Stereotype

The present investigation provides strong, consistent evidence for a multi- category female stereotype. The category listing tasks, the attribute listing tasks and the factor analysis of those attributes resulted in converging evidence for at least four cistinct stereotypic roles; housewife, career woman, sex object and female athlete. A fifth role, women's libber, also emerged but was not as well-defined as the others. The veridicality of these stereotypic roles, moreover, is suggested by the remarkable similiarity of these categories to those reported by Clifton et $\operatorname{al}(1976)$.

Employing a different methodology and including a different subject population (midile class suburbanites), those authors identified five stereotypic female roles; housewife, career woman, bunny/sex object, female athlete and clubwoman. These roles were partially based on subject generated responses, which was wholly the case in the present work. Given this methodological format, the consistency of the stereotypic roles is impressive.

Furthermore, validation of the stereotypic roles in the present research was providea by factor analysis of 663 responses to the attribute scale. Four of the five roles emerged as strong clusters with the appropriate attributes defining each fron the attribute listing task. Clifton et 
$\vec{a}(1976)$ usec a pre-deternined acjective checklist of 153 items to characterize roles rather than subject cenerateci descriptions. inonetheless, the type of attribltes cescribing each role was similar, although the actual attributes were aifferent in the two stuâies. For example, Clifton et al(1976) found that only 10 of their 153 adjectives were used to cescribe three or more roles. Half of these were actually anong those shared by roles in the present study. Their data also showed that the most overlap occurred among athlete, career wonan and cluboman, a Finding parallelea in the present study by athlete, career woman anc libber (See Tables 9 and 20 ).

Table 20. Shared adjectives across roles in the Clifton et al $(1976)$ study.

\begin{tabular}{|c|c|c|c|c|c|}
\hline AQjective & Eousewife & Athlete & $\begin{array}{l}\text { Role } \\
\text { Career } \\
\text { Womar }\end{array}$ & $\begin{array}{c}\text { Sex } \\
\text { object }\end{array}$ & Clubwoman \\
\hline $\begin{array}{l}\text { active } \\
\text { alert } \\
\text { aggressive* } \\
\text { harciorking* } \\
\text { conficht* } \\
\text { antitious* } \\
\text { competitive } \\
\text { persistent } \\
\text { ingependent* } \\
\text { adventurous }\end{array}$ & $\begin{array}{l}x \\
x\end{array}$ & $\begin{array}{l}x \\
x \\
x \\
x \\
x \\
x \\
x \\
x \\
x \\
x \\
x\end{array}$ & $\begin{array}{l}X \\
X \\
X \\
X \\
X \\
X \\
X \\
X \\
X \\
X \\
X \\
X\end{array}$ & $x$ & $\begin{array}{l}x \\
X \\
x \\
y \\
X \\
X \\
X \\
y \\
X \\
X \\
X \\
X \\
X\end{array}$ \\
\hline
\end{tabular}

* adjectives also snared by roles in the present stuci

However, the degree of role overlap was consicierably less in the present study. Table 21 shows the percentage of cistinctive attributes for stereotypic roles for the Clifton et al(1976) and the present data. 
Table 21. Percentage of distinctive attritutes for roles in the present and Clifton et al(1976) stlidies.

Role

Present stucy

Clifton et al

percentage

percentage

Housewife

87

56

Athlete

60

17

Career Woman:

62

27

Sex object

77

66

Libber/Clubwcman

64

9

Although the pattern of role overlap is the sane, i.e., housewife and sex object share ferer attrikutes than the other three roles, it is evident that all roles are more aistirctive in the present stuay. It would appear that the different methocologies emplcyed by the two studies account for this variance. In the present stucy, attributes were Senerated by subjects as those that were typical of and comon to memicers of each role. In this way, subjects volid generate highly distinctive characteristics for each role. Clifton et al's(1976) adjective checklist, or the cther hand, containea items that were rot chosen empirically on the basis of role distinctiveness or tyoicality. Consequently, many of the items that subjects vould corsicer distinctive may not have been on the list, as evidencec by the different attributes generated by subjects in this 
research. As well, many of the items may have been considerec irrelevart. The checklist would therefcre lead to more similar profiles than may actually exist.

Nonetheless, the present study does extend the findings of Clifton et al(1976) and both studies indicate that the assumption of a single-category female stereotype requires revision. Inceed, the only role that paralleled the traditional content of the female sex-role stereotype was the housewife role. The sex object role, al though recognizably feminine from media images of women, contained attributes not found on any traditional sex stereotype scale (e.g., beautiful, secuctive, good figure, fashion conscious). Noreover, the renaining stereotypic roles were strikingly "male" in content. The strong, cistinctive career woman stereotype was cescribed as intelligent, ambiticus, determined, strong-minded, independent and goal-oriented, traits tracitionally attributed to the male stereotype. Similarly the female athlete stereotype was Cescribed as energetic, harcworking, cedicated, co-orcinatec and sports-oriented.

Yet all but three of the attributes that subjects Lised to describe women in general were traditionally feminine traits. It appears that asking people to cescribe a single female stereotype elicits traditional cultural prescriptions of the female role. Asking people to describe different kinàs of women, however, allows them to cepart fron such prescriptions and äraw on their own experiences or a variety of cultural prescriptions. The traditional 
stereotype still energes, in the form of the housewife role, which, in fact, shared more attribltes in comon with women in general than any other role (30 per cent). However, other quite cistinct roles also emerge.

Furthermore, it would appear that these untraditional roles for women may not be perceived as negatively as most sex-role stereotype research vould suggest. When a random sample of the subjects in this investigation $(n=60)$ were asked to rank oraer the desirability of the five stereotypic roles for women, both males and females ranked career woman as the most desirable role, followed by housewife and then athlete. Interestingly, men and women showed opposite rankings of the remaining two roles, with women ranking sex objects and men ranking libbers as least desirable. Earlier data (Study 4) also showed that women listec more negative attributes for sex objects and men listec more negative attributes for libbers. These data are merely suggestive, but they indicate that future research should examine the social desirability and evaluation of these roles and their respective attributes comprehensively. Finally, then, this investigation adis another dimension to the many criticisms of sey-role research methodology (Brannon,1978;Kelly \& Norell,1977; Pechazur \& Tetenbam, 1979). Nost studies of sex-role stereotyes use checklist responses rather than self-generated descriptions (Rasow,1980; Cicone \& Puble,1978). The former method has been criticized for leading to exaggerated stereotypes since they encourage people to respond on the basis of beliefs 
rather than actual experience (Cicone \& Ruble,1978); for over-emphasizing attributes that differentiate the sexes since questionaires focus on male-female cifferences rather than asking questions on typicality (Cicone \& Ruble,1978); for creating "all-or-none", polar distinctions between the sexes since checklists are usually presented in polar form (Basow, 1980; Brannon,1978).

This investigation suggests that the commonly held single category female stereotype is more a function of method than reality. When people are not restricted and channeled by the checklist format, they respond with considerably richer and more varied categories than simply "female". Inceed, many subjects in this stuciy incicated that to cescribe the "typical" woman was most difficult to do. It woulc seem from a cognitive point of view, that this is too molar a unit to be useful in person cescriptions. As demonstrated in Study 5 , people are much more likely to use a less inclusive unit, such as housewife or career voman, that conveys richer, more detailed information and herce is easier to describe. People will also cescribe some of these roles in tracitionally "masculine" terms. It may be that the polar distinctions between the sexes very much depend on role rather than sex.

Whether or not the social cognitive analysis employed here will reveal that the extent anci polarity of sex-role differences has been over-emphasized by traditional methodologies remains to be seen. Future research, replicating the methocs usec here for male stereotypes, must 
Iirst be corpletec. This resezch has alreaby begur. Exploration of the male sex-role stereotype per se is important as well as comparisons with the cata gatherec here on the female sex-role stereotyge. Foreover, these data will enable incorforation of male sex-role(s) attributes with those for female sex-roles on an empirical scale. Refinement and validation of such a scale may overcome many of the difficulties inherent in present scales that are tasec solely on checklist wethociologies and researchers" "a priori" views of sex-roles. Extensicn of this research with representative age, demographic and socio-economic groups is an important focus for the future. Such work shoula contribute to a more ecolcgically valid conceptualization and measurement of sex-role stereotypes than is currently available.

2. The Social Cognitive Analysis of Stereotypes

The series of studies reported here also provide converging eviojence for the utility of a cognitive approach to the study of stereotypes. The emphasis of this aperoach on the limitations of the information processor is an important one. It focuses on the mechanisms people encloy to cope with vast anourts of information input and the bieses inherent in such mechanisms. One oi the most pervasive of these mechanisms, categorization, is also ar essential element to stereotyping. Eifferential perceptior anci behaviour evident in stereotyping involves categorizing 
people into a variety of groupings. Consequently, this apprach leacs to a view of stereotypes as categorization schemas with attributes such as sex or race tagged to category labels or prototyres.

The present research supports this conceptualization of stereotypes. The adaptation of Rosch's(1976) ard Cantor's(1977) methods to delineate the categories that comprise stereotypic schemas proved successful. The free format methocology used here, which aid rot restrict either the number or type of categories, yielced remarkably consistent results. Moreover, the structural organization of the stereotypic categories was found to te the same as that reported for other object and person taxonomies lCantor \& Mischel,1979; Rosch, 1976). The converging evidence for the categorization model is therefore impressive. loreover, the similarity of the organization of the female sex-role sterectype to other ferson prototypes provides strong evidence for the interpretation of stereotypes as categorization schenas.

Perhaps most importantly, the meciational Eunction of stereotypic categorization schemas was also supported. Such schemas do inceea bias memory toward the stereotype and stereotypic attributes do seem to be grouped together in memory. Such data clearly support the premize of the biasing nature of information processing mechanisms. Certainly, the present research woulc warrant tre application of the categorization model and methoc's to other stereotyoic areas, such as race and etrnicity. Indeed, such 
research wolic provide nuch useful information on the stereotypes per se, as well as adiress questions heretofore not easily raisec. In particular, questions concerning the organizational and functional correspondence among different kinàs of stereotypes can be explored. It would also be interesting to assess whether or not racial, ethric or cultural categories are as consensual as sex-role ones, as well as what factors contribute to consensus.

Developmental questions would be particularly interesting to explore from this point of view. For example, do different age groups have different stereotypic schemas? Are they organized and do they function in the same way?

The role of stereotypic categories in the person perception process is perhaps the most important ultimate question here. Initially, what cues activate the stereotype? How is one identified as a member of a stereotypic category? Considerable evidence indicates that stimulus salience is a crucial factor in such perceptions and cues such as sex and race are salient by virtue of their physical prominence and distinctiveness (Hamilton, 1979; Taylor \& Fiske, 1978). However, what are the salient cues that identify less inclusive, and less distinctive, stereotypic categories, such as housewife or career woman? some preliminary work on this question has already begun by asking subjects to describe their visual image of a typical housewife, career woman, etc.. Consensus scoring of these cata will hopefully reveal some of the visual/ nonverbal 
cues that people use to icertify these role members. Sinilar tasks eliciting typical behaviours should icentify context clies that are important. once such cues are identifiec, then experimental work can be conducted to determine if manipulation of such cues influences role attributions.

The arta reported here on stereotypic categorization schemas contribute to the growing body of evidence on stereotypes from a social cocnitive perspective (e.g., Hamilton;1976;1979; Taylor et al,1978). There seems little coubt that the conception of stereotypes in terms of normal cognitive processes and the adaptation of cognitive methalogy to study sane will continue to stimulate important questions and data.

Traditional conceptions of stereotypes have given little attention to the cognitive processes that may proauce differential Ferception of social groups. Since its introguction, the tern stereotype ras been vieweci as involving rather unique processes that gresuably set stereotypes apart from other kinäs of beiiezs (5rennon,1978; Brigham, 1972; Lamilton,1979). Researchers have enphasizec this uniqueness, arguing that the development anci use of stereotypes has motivational roots and is of functional value to the incividual (Hamilton, 1979). Such forces have. been assunea to influence the indivicual's cognitive functioning such that stereotypirg is vieved as the procuct of erroneous and atypical thought processos.

Research Irom the social cognitive point of vien 
incicates that stereotypes co not necessarily involve distorted thought processes. Indeed, the growing body of research provides convincing, converging evidence that stereotypes can result simply from cognitive mechanisns involved in normal information processing.

This is not to deny the importance of social learning experiences or motivational factors in stereotypes. Indeed, it would seem likely that much of what people believe and feel about stereotyped groups is acquired through social learning processes. Moreover, motivational factors may well facilitate the acquisition and/or maintenance of prevailing stereotypes. However, even when such processes play a central role, their ultimate effects are recessarily mediated by the perceiver's cognitive processes. The nature of the mechanisms involved in such meciating processes have been virtually ignored by more traditional approaches. The focus of the social cognitive perspective on these mechanisms is therefore complementary to the more traditicnal research in adaressing an area essential to an understanding of stereotypes. 
Deison, F. Scrizt proceseing ir attituce fornation and decision neking. In J.S.Carroll $\varepsilon$ J.J.Payne (ECs.), Cognitior anc Social Bereviour Hillsciale, H. J. : Erl tá tur, 1976.

Fllen, V.L. E vilder, D.A. Catgeorization, belief similarity anci intergroup discrimination. Journal Perscrality \& Social Psycholccy,1975,32(6),971-977.

Basow, S.A. Sex-role Stereotyoes: Iracitions and Alternatives Calif.,Brooks/Cole, l 580 .

Beri, S.L. Cognitive processes meciating sex typing and androgyny. Invited adaress at the meetings of the Westerr Fsycholosical Association, San Francisco, April, 1978 .

Eoustieldi, A.R. \& Bousfield, M.A. Yeasurement of clistering anc sequential constancies in repeatec free recall. Esychological ieports,1956,19,935-942.

Brannon, R. Neasuring attitudes toward vomen land otherwise): A methodological critigue. In J.P. Sherman \& F.L.Dennark (Eds.), The Fsuchology of vomen: Future Directions in Research. H. Y.,Psycholcgical Eimensions, 1978 . 
Erigham, J.C. Ethric stereotypes. Esycholosicel Bulletir, 1971,76(1),15-38.

Eroverman, I. .., Vocel, S., Broverman, D., Clarkscn, F. \& Rosenkrantz, P. Sex-role stereotypes: a current appraisal. Journal of Social Issues, 1972,28(2), 59-78.

Cantor, R. Prototyoicality and personelity. Unpublished manuscrigt, 1977, Stanford University.

Cantor, $\mathrm{N}$. Prototypicality and personality juggerents. Unpublished Doctoral Dissertation, 1978, Stenforc University.

Cantor, recognition. Journal of Personality \& social Psychology, $1977,35(1), 38-48$

Cantor, M. \& lischel, W. Prototypes in pereon cerception. Advances in Experimental Social Psycholcoy, 1979,12,2-51.

Child, D. The Essentials of Factor Analysis N. Y.,Holt, Rinehart \& Tinstor, 1978.

Cicone, H.V. \& Euble, D.t. Eeliefs abcut teles. Journal of Social Issues, $1978,3 d(1), 5-16$. 
Clifton, A.r., l:CCrath, E. \& rich, E. Stereotypes of

woman: a Eirgle category? Sex

Roles, 1576,2(2),135-1@8.

Cohen, c. Cognitive basis of stereotyping. Paper presenteć at the meetings of the American Psychological Association, San Francisco,1977.

Duncan, E.I. Differential social perception and attribution of intergroup violence: testing the lcwer linita of stereotyping ō blacks. Journal of Fersonality \& Social Esychology, $1976,34(4), 590 \rightarrow 598$.

Ehrlich, H.J. The Social Esychology of Prejuaice N.Y. rilley, 1973 .

Ehrlich, H.J. E Rinehart, J.H. A brief report on the methociology of stereotyce research. Social Forces, 1965,43,564-575.

Fiske, S. s Cox, M. Describing others: there's more to person perception than trait lists. Paper preserted at the meetirgs of the American Psychological Asscciation, San Francisco,1977.

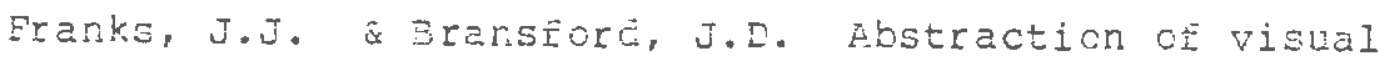
patterns. Journal of Experimental Psychology, I971,90,65-74. 
Friencily, i.t. In search of the :-Grem: the structure of organization in free recall. Cocnitive Psychology, $1977,9,18 \varepsilon-249$.

Gurwitz, S.B. \& Dodge, K.A. Effects of confirmations and disconfirmations on stereotype-based attritutions. Journal of Personality \& Social Esychology, $1977,35(7), 495-500$.

Harilton, D.L. Cognitive biases in the perception of social Groups. In J.S.Carroll \& J.V.Payne (Eds.), Cognition and Social Behaviour Hillsciele, M.J., Erltal th, 1976.

Eanilton, D.L. A cognitive-attritutional aralysis of stereotyping. Advances in Experimental social Psychology, 1979,12,53-84.

Damilton, D.L. \& Giffort, R.K. Illusory correlation in interfersonal perception: a cosnitive basis of stereotypic jucigenents. Journal of Experinental Social Psychology,1976,12,392-407.

Hamilton, D.L., Katz, L.B. \& Leirer, V.O. Organizational processes in impression formation. In P.pastie, T.Cstron, E.Ftbsen, 只范er, D. Fanilton \& D.Carlston

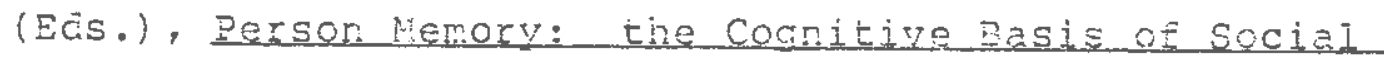
Perception Hillsciale, H.J., Erlbaun, 1980. 
Hamilton, D.L. \& Rose, T.L. Illusory correlation and the maintenance of stereotypic beliess. Journal of Personality ard Sociel psychology, 1980,38,832-\$45.

Harmar, H. E. Hodern Eactor Analvsis Chicago, Ill, , University of Chicago Press,1967.

Hastie, R. \& Carlston, D. Theoretical issues in person memory. In R. Hastie, T.Ostrom, E.Ebbsen, R.wyer, D. Hamilton \& D.Carlston (Eds.), Person lierory: the Cognitive Easis of Social percepticr, IIillsciale, N.J. ,Erlta um, 1980 .

Hastie, R. Memory for tehavioural information that conitirms or contradicts a personality inpression. In R. Eastie, T.Ostron, E.Ebbser, R. Wyer, D.Hamilton \& D.Carlston (Eds.), Perscn liemory: the Cognitive Dasis of Social Perception Hillscale, N.J., Erlbaum, 1980.

Higgins, E., Rholes, wi. \& Jones, C. Category accessibility and imprassion formation. Journal of Experimental Social Psychology,1977,13,141-154.

vanter, $\because$. some effects of proportions on group life: skewed sex ratics and responses to token women. American Journal of Sociology, $1977,82,965-990$. 
Laiser, H.F. The varimax criterion for analytic rotation in factor analysis. PSychometrika,1958,23,187-200.

Kelly, J.A. \& Norell, J. New formulations of sex roles: a critical review. Journal of Consulting \& Clinical Psychology, $1977,45(6), 1101-1115$.

Kluckholn, F.R. American women and American values. In L.Bryon (Ed.) Facing Euture Risks N.Y., Harper, 1973 .

Lakoff, G.A. A study in meaning criteria and the logic of fuzzy concepts. Paper presented at the Eighth Regional heeting, Chicago Linguistics Society, Chicago,1972.

McArthur, L. \& Friecman, S. Illusory correlation in impression formation: variations in the shared distinctiveness effect as a function of the distinctive person's age, race and sex. Journal of Personality \& Social Psychology, $1980,39(4), 615-624$.

McCloskey, H.E. \& Glucksberg, S. Natural categories: well-defined or fuzzy sets? Memory \& Cognition, $1978,614,462-472$. 


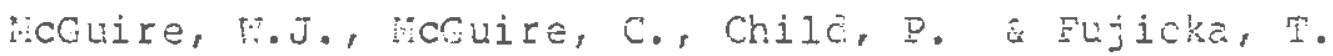
Salience of etrnicity in the spontareolis seli-corcept as a function of one's ethric distinctiveness in the social environment. Journal of Personality s Social Psychology, $1978,36,511-520$

Mischel, W. Jeffrey, K. \& Patterson, $C$. The layman's use of trait anci behavioural information to predict behaviour. Journal of Fesearch in Personality, 1974,8,231-242.

linsky, I.A. A framework for representing knowleçe. In P.H.Winston (Ed.) The Psychology of Computer Vision M.Y. ,HCGraw-Hill, 1975 .

Oşood, C.E., Suci, G.J. \& Tannenbaum, P.H. The Heasurement of Heaning Ill. University of Illinois Press, 1957

Pechazur, E.J. E Tetenbaum, T.J. Eem Sex Role Inventory: a theoretical and methociological critiolue. Journal cf Personality E Social Psychology,1079, 37(6), 996-1015.

Pleck, J.H. Kasculinity-feminirity clurent anci alternetive paradigns. Sex Doles,1975,1(2),161-178. 
Fosner, H.I. \& Keele, s.n. on the genesis of abstract ideas. Journal of Experimental Psychology, $1968,77,353-363$.

Posner, M.I. \& Keele, S.W. Retention of abstract ideas. Journal of Experimental Psychology,1970,83,304-308.

Quine, w.v. Ontological Relativity and Other Essays N.Y. , Columbia University Press, 1969.

Reed, S.K. Pattern recognition and categorization. Cognitive Psychology, 1972,3,382-407.

Reitman, J.S. \& Bower, G.H. Storage and later recognition of exemplars of concepts. Cognitive Psychology, 1973,4,194-206.

Rosch, E. Cognitive reference points. Cognitive Psychology, 1975,1,532-547.

Rosch, E. Principles of categorization. In E.Rosch \& B.Lloyd (Eds.) Cognition and Categorization Hillsciale, N.J., Erlbaum, 1978.

Rosch, E. \& Mervis, C. Eamily resemblance: studies in the interrai structure of categories. Cognitive Psychology, $1975,7,573-605$. 
Rosch, E., Nervis, C., Grey, T., Jonnson, I. \& Boyes-Ẽraen, P. Easic objects in natural categories. Cognitive Psych ol ogy, $1976,8,382-439$

Rothbart, M., Evans, M. \& Fulero, S. Recall for confirming events: memory processes and the maintenance of socia1 stereotypes. Journal of Experimental Social Psychology, $1979,15,343-355$

Ruble, I.M. \& Ruble, T.L. Sex stereotypes. In A. G. Miller (Eä.) In the Eye of the Seholder: Contemporary Issues in Stereotyoing N.Y. Ho1t, Rinehart \& Vinston, 1980

Schank, R. \& Abelson, R. Scripts, Plans, Goals_and understarding Eillsciale, No.J., Erl baun, 1977.

Schneider, D., Hastorf, A. \& Ellsworth, P. Person Perception Reaäing, Ma., Adàison-Wesley, 1979.

Snyder, M. \& Uranowitz, S. Reconstructing the past: some cognitive conseguences of person perception. Journal of Personality \& Social Psychology, $1978,36(9), 941-950$.

Srull, T.K. \& ryer, R. Category accessibility and sociel perception: sone implications for the study of person memory and interpersonal juagenents. Journal of Personality \& Social Psychology,1500,38(6),841-856. 
Sterrberg, R.J. S Tulving, E. The reasurenent of subjective organization in free recall. Esycholçical Elilletin, $1977,84,539-556$.

Tajfel, H., Billig, H., Buncy, R. E Flament, C. Social categorization and intergroup behaviour. European Journal of Social Psychology, 1971,1,149-178.

Taylor, S.E. \& Fiske, S.T. Salience, attention and attribution: top of the head phenomena. Aavances in Experimental Social Psychology,1978,11,249-288.

Taylor, S., Fiske, S., Close, H., Anderson, C. \& Euderman, A. Solo status as a psychological variable: the power of being distinctive. Unpublished manuscript, Harvard university, 1977 .

Taylor, S.E., Fiske, S.T., Etcoff, N.L. \& Puderman, ス.J. Categorical and contextual bases of person memory anc stereotyping. Journal of Personality \& Social Psychology, $1978,36,778-793$.

Tsujinoto, R. Nemory bias towaro normative and novel trait prototypes. Journal of Personality \& Social Psychology, 1978,36(12),1391-1401.

Turner, F.s. Fanily Interaction M.Y., Niley,1970. 
Tversky, A. Features of similarity. Fsychological Revív, 1577,84, 327-352.

Winer, B.J. Statistical principles in Experimental Desicn N.Y. HCGraw-Fil1, 1971 .

Wolman, C. \& Frank, H. The solo womar in a professional peer group. Iifierican Journal of Orthopsychiatry, 1975,45,165-171.

Tyer, P. E SruIl, T. The prccessirg of social stimulus information: a conceptual integration. In P. Hastie, T. Ostron, E.Ebbsen, R. Wyer, D.Familton \& D.Carlston (Eas.) Derson "iemory: the Cocnitive Basis of Social Perception 
Appendix $\mathrm{I}$ 
Table 1. Number and percentage(*) of slibjects, by sex, who classified women lising types, traits or both types anà traits

Sex

Type

Classification Category Trait Eoth

Total

Male

Female

$25(29)$

$39(36)$

$32(38)$

$28(33)$

85

Total

$63(32)$

$30(28)$

$39(36)$

108

$63(32)$

$67(35)$

193

$x=2.23$, df $=2$, not significant (*)percentage in bracket

Table 2. Means, Standarc deviations anc t-test for number of attributes listed by sex for the classification of women task

\begin{tabular}{|c|c|c|c|c|c|}
\hline Sex & Ni & $\begin{array}{l}\text { Rean No. } \\
\text { listed }\end{array}$ & S.D. & $t$ & dif \\
\hline $\begin{array}{l}\text { Nale } \\
\text { Female }\end{array}$ & $\begin{array}{l}53 \\
78\end{array}$ & $\begin{array}{l}8.69 \\
7.51\end{array}$ & $\begin{array}{l}6.44 \\
5.11\end{array}$ & 1.17 & 129 \\
\hline
\end{tabular}

Table 3. Means, Standard deviations and t-test for number of types listed, by sex, for the classification-ofwomen task

Sex N $\begin{gathered}\text { Mean No. S.D. } \\ \text { listed }\end{gathered}$ df $P$

Male

Female

53

4.90

78

2.79

2.11

$0.05 \quad 129$

N.S. 


\section{APPENDIX I}

Table 4. Categories listed in the midile-level category generation task that dic not meet the 50 percent inclusion criterion (reportec by less than 10 percent of subjects and listed in order of frequency)

classy women (1)

high-class snob

lesbians/gays

divorcees

married women

single women

upper-class sophisticates

bitches

businesswomen

olc-fashionea types

prostitutes

hookers

tall women

short women

fat women

skinny women

students

conformists (18) masculine women (19)

soap-opera sals

girl-next-door

tramps

entertainers

busy bodies

racoicals

religious fanatics

gossips

rags

educated womer.

unecucated women

tomboys

frienas

those concernec-

regarcing appearance

traditional vomen (34)

Reported only once:

jerks

exhibitionists

whores

artsy-craftsy types

modern women

holy-rollers

social butterflies

VIP women

fakes

well dressed vs slobs

snobs

leacers vs followers

homey types

flirts

upper-class sophisticates

lower-class rough

wives

intellectuals

sexists

outdoors types

exhibitionists foxy ladies

prissy types

hussies

grandma types

spinsters

romantics

companions

chicks

young vs old

runs

non-workers

submitters vs cominators

virgins

individualist vs passive type

middle-class working women

achievers vs non-achievers

militants

social climbers

nature lovers

cover-girl types 
Apgendix II 
Table I. Number cû subjects who classifiech housewives, career women, sex objects, women athletes arc romen libbera on the basis of types, traits or both types and traits, by sex.

SEX: Female

Role Category Classification Category

Types Traits Eoth Do Response Total

\begin{tabular}{llllll}
\hline Career women & 41 & 1 & 4 & - & 46 \\
Eousewives & 34 & 3 & 8 & 1 & 46 \\
Tomen athletes & 36 & 4 & 4 & 2 & 46 \\
Sex otjects & 33 & 6 & 4 & 3 & 46 \\
Tomen's libbers & 21 & 10 & 7 & 8 & 46 \\
\hline
\end{tabular}

SEX: räle

Role Category Classification Category

Types Traits Both r:o Response Total

\begin{tabular}{llllll}
\hline Career wonen & 38 & 1 & 2 & - & 41 \\
Housevives & 30 & 8 & 3 & - & 41 \\
Women athletes & 35 & 3 & 2 & 1 & 41 \\
Sex objects & 33 & 5 & 3 & - & 41 \\
Tomen's libbers & 20 & 5 & 2 & 10 & 41 \\
\hline
\end{tabular}


Table 2. Total and mear rumber of types listed for 5 female roles, ty sex

Role Category

Males

Ferales

Total $X$ S.D. Total X S.D.

Career wonen

$\begin{array}{lll}311 & 7.58 & 5.33\end{array}$

$278 \quad 6.04 \quad 3.41$

rouserives

$\begin{array}{lll}95 & 2.57 & 1.24\end{array}$

$120 \quad 2.72$

1.21

Homen atheletes

$177 \quad 4.54$

2.47

$151 \quad 4.44$

1.21

Sex objects

1143.00

1.68

$100 \quad 2.34$

1.34

Women's libbers

$63 \quad 2.03$

1.14

\&o 2.22

1.17

All categories

$760 \quad 4.08$

3.55

$769 \quad 3.63$

2.99 
Table 3. Subcategories listed for the five fenale roles for each sez. (Not listea in orcer of frecuency, but rather to indicate correspondence ketween female and male responses).

Male responses

\section{Housewives :}

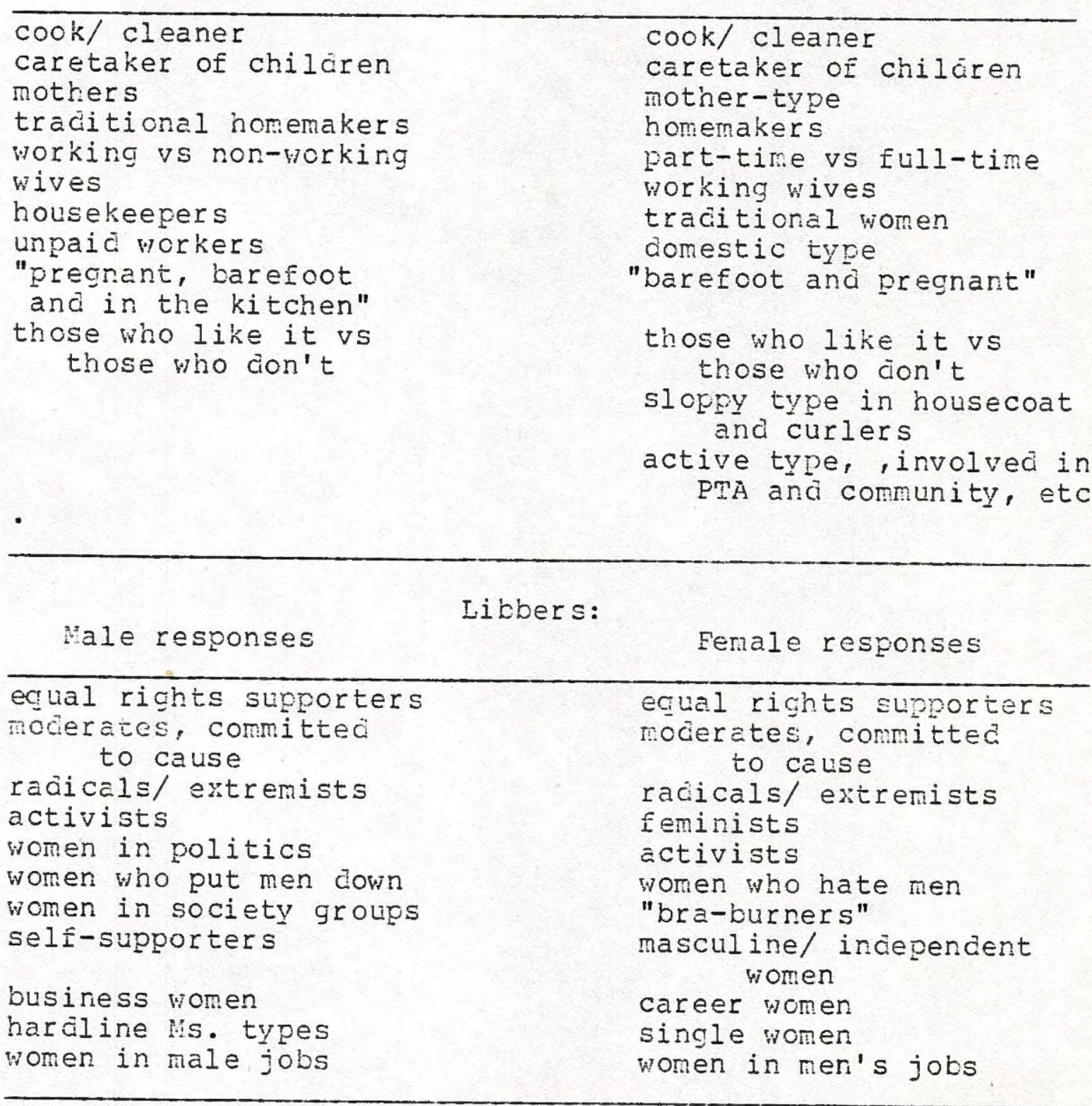

Fenale responses 
Table 3. (cont'a) Subcategories listed for the five female roles for each sex. (liot Iisted in order of frequency, but rather to incicate correspondence between female arci male responses).

\begin{tabular}{|c|c|c|}
\hline Male responses & Career women: & Female responses \\
\hline $\begin{array}{l}\text { doctor } \\
\text { teacher } \\
\text { nurse } \\
\text { lawyer } \\
\text { business executive } \\
\text { secretary } \\
\text { policewoman } \\
\text { politicians } \\
\text { saleswomen } \\
\text { social workers } \\
\text { actresses } \\
\text { scientists } \\
\text { judges } \\
\text { designers } \\
\text { professors } \\
\text { accountants } \\
\text { dentists } \\
\text { models } \\
\text { stewardesses } \\
\text { waitresses } \\
\text { engineers } \\
\text { typists } \\
\text { librarians } \\
\text { educated women } \\
\text { artists } \\
\text { authoritative women }\end{array}$ & & $\begin{array}{l}\text { doctor } \\
\text { teacher } \\
\text { nurse } \\
\text { lawyer } \\
\text { business executive } \\
\text { secretary } \\
\text { politicians } \\
\text { sales clerks } \\
\text { social workers } \\
\text { actresses } \\
\text { scientists } \\
\text { journalists } \\
\text { bus crivers } \\
\text { professors } \\
\text { accountants } \\
\text { hair stylists } \\
\text { mocels } \\
\text { stewardesses } \\
\text { waitresses } \\
\text { engineers } \\
\text { single women } \\
\text { librarians } \\
\text { professional women } \\
\text { artists } \\
\text { singers } \\
\text { women who work for their } \\
\text { women who work to support } \\
\text { the fanily } \\
\text { part-time vs full-time }\end{array}$ \\
\hline
\end{tabular}


Table 3.(cont'ä) Subcatẹories listed for the five female roles for each sex. (Not listed in orcier of frequency, but rather to incicate correspondence between female and male responses).

\begin{tabular}{|c|c|}
\hline Wale responses Sex Cbjects: & Fenale responses \\
\hline $\begin{array}{l}\text { movie stars/actresses } \\
\text { playboy bunnies } \\
\text { models } \\
\text { strippers } \\
\text { blondes } \\
\text { advertisement girls } \\
\text { hookers } \\
\text { center-folcs } \\
\text { singers } \\
\text { Eo Derek types } \\
\text { beautiful women } \\
\text { stewardesses } \\
\text { belly dancers } \\
\text { brunettes } \\
\text { celebrities } \\
\text { topless waitresses } \\
\text { dancers } \\
\text { intelligent women }\end{array}$ & $\begin{array}{l}\text { movie stars/ actresses } \\
\text { playboy bunnies } \\
\text { models } \\
\text { strippers } \\
\text { blondes } \\
\text { acivertisement girls } \\
\text { hookers } \\
\text { center-folcs } \\
\text { singers } \\
\text { Bo Derek types (*) } \\
\text { beautiful women } \\
\text { recheads } \\
\text { belly dancers } \\
\text { brunettes } \\
\text { pin-up girls } \\
\text { topless waitresses } \\
\text { secretaries } \\
\text { healthy women } \\
\text { Ilirts/ teasers }\end{array}$ \\
\hline
\end{tabular}

(*) Actress star in movie "10" (1981) 
Table 3.(cont'a) Subcategories listeä for the Eive ferale rcles for each sez. (liot listec in orcer of ireguency, but rather to incicate corresponatice between ímale anc male responses).

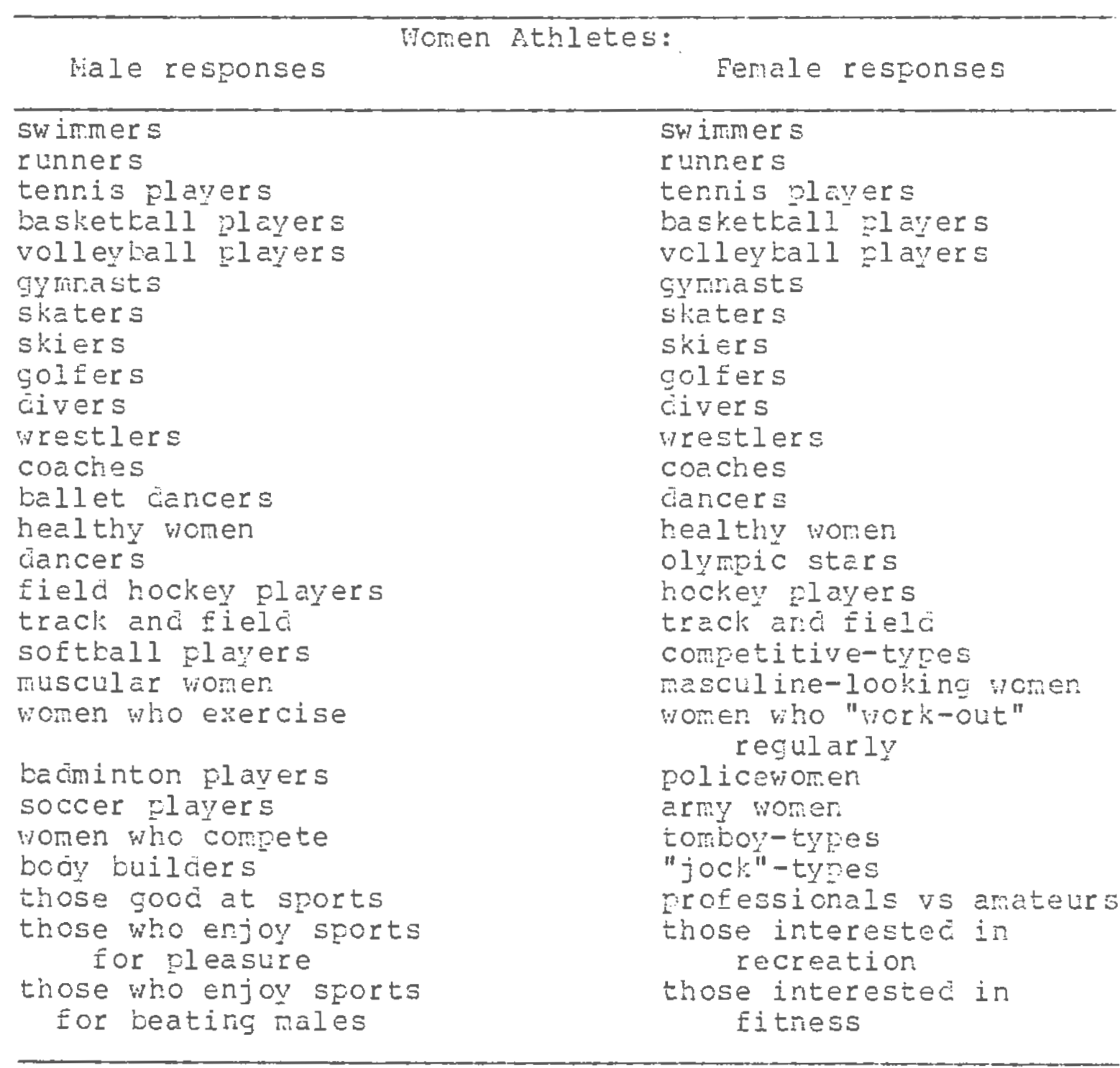


Appercis III 
APPESIIXII

Table 1. Vear percentage ratings of attributes from the attribute listinc task describirg rons:

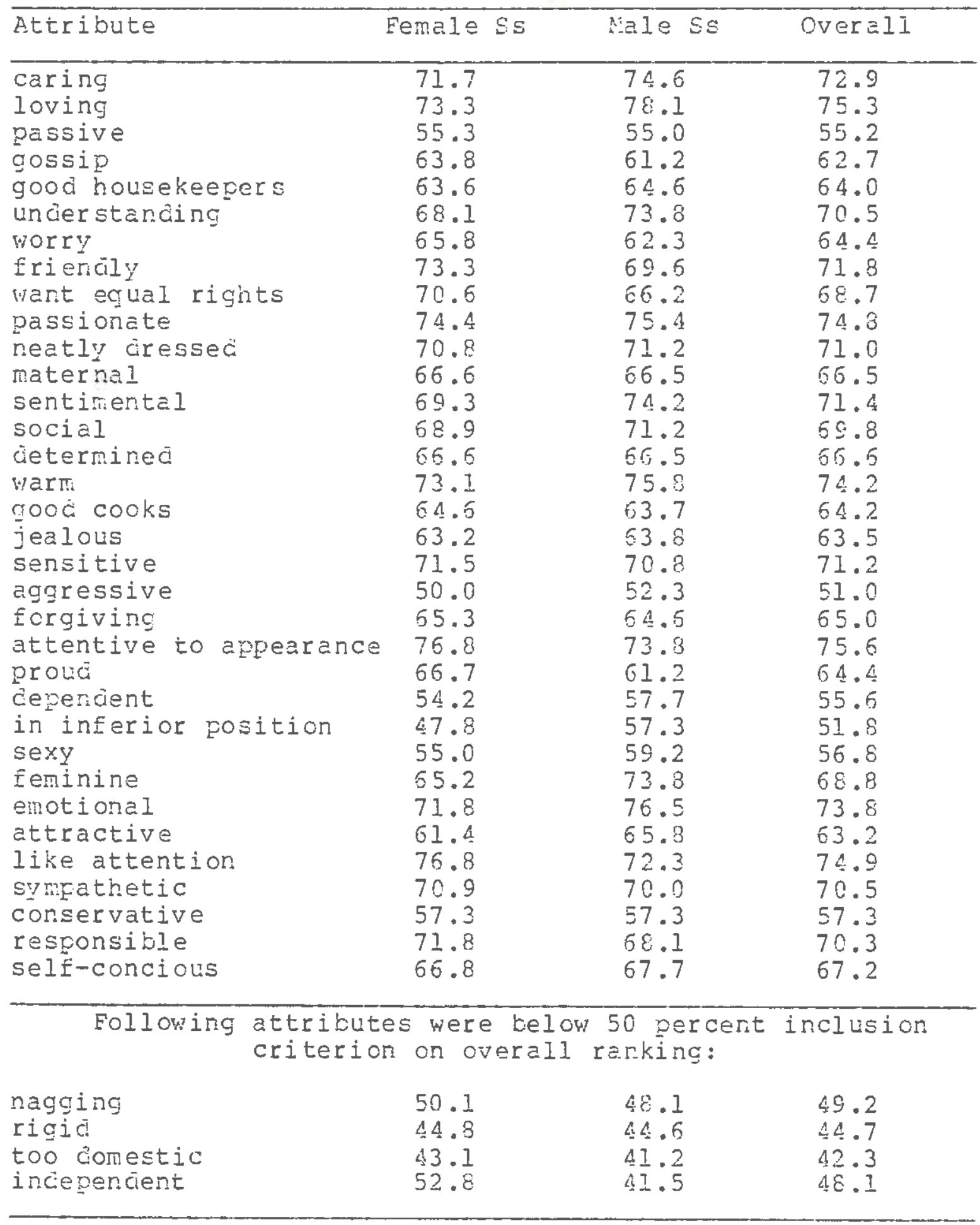


ADOEYIIIY III

Table 2. liean percentege ratirgs of attritutes from the attribute listirg task describing CAPERR TOREN

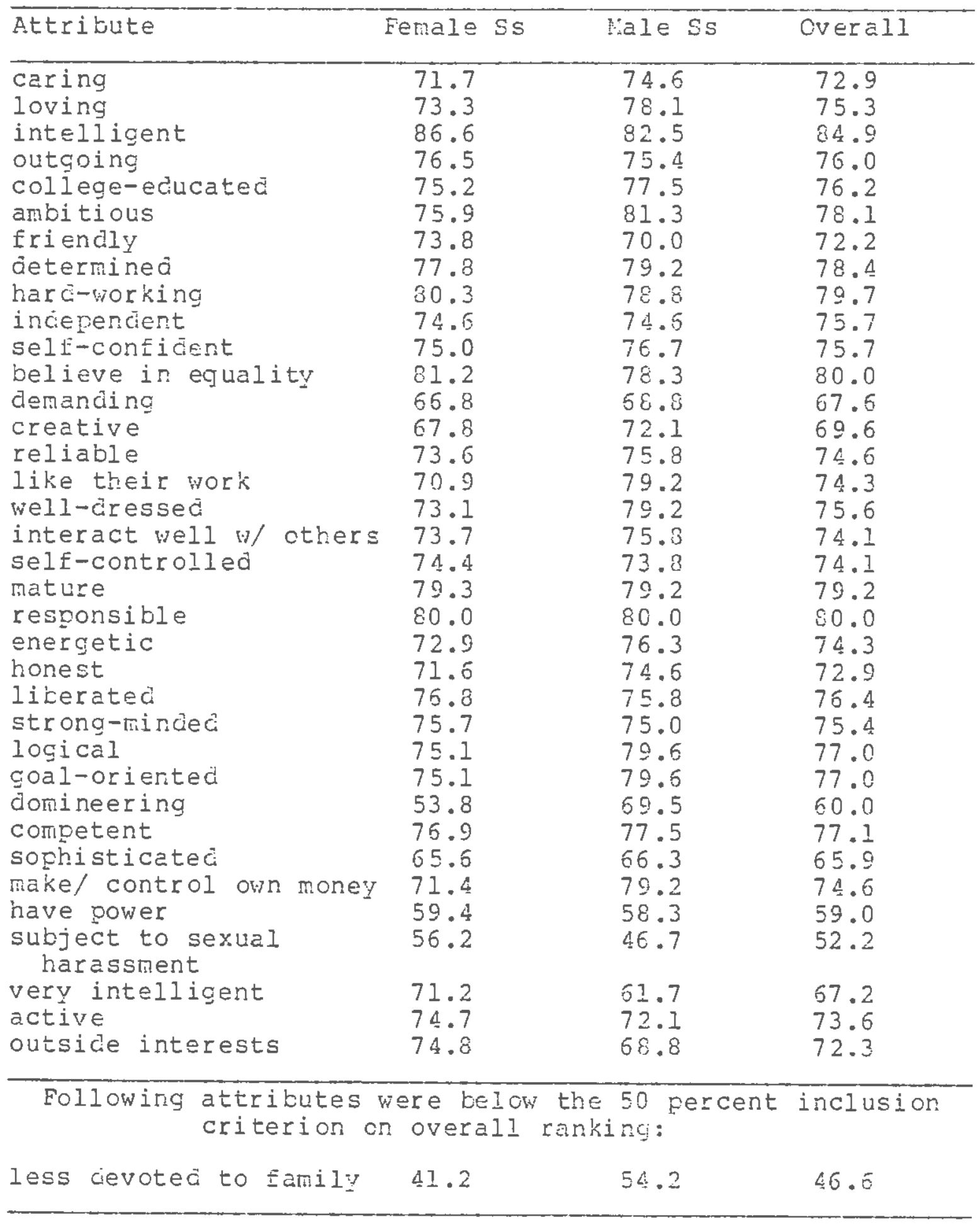


APEEPTIX III

Table 3. Mean fercentage ratings of attributes from the attribute listing task cescribing FEIMLE BrEgrens

\begin{tabular}{|c|c|c|c|}
\hline Attribute & Eetiale ss & Hale SS & OveraIl \\
\hline tall & 68.1 & 64.0 & 66.4 \\
\hline anbitious & 82.5 & 77.7 & 80.5 \\
\hline non-arinker/smoker & 79.4 & 79.6 & 79.5 \\
\hline energetic & 88.3 & 83.5 & 86.3 \\
\hline heal thy & 90.9 & 87.2 & 89.4 \\
\hline sports-oriented & 90.4 & 84.2 & 87.8 \\
\hline slin & 83.0 & 75.0 & 79.7 \\
\hline outgoing & 79.2 & 71.2 & 75.8 \\
\hline intelligent & 75.0 & 69.6 & 72.7 \\
\hline deternined & 84.7 & 79.6 & 82.8 \\
\hline muscular & 74.8 & 57.7 & 67.6 \\
\hline flat-chested & 56.4 & 54.6 & 55.6 \\
\hline aggressive & 68.2 & 67.7 & 68.0 \\
\hline inciependent & 71.7 & 61.9 & 67.6 \\
\hline short hair & 67.2 & 63.1 & 55.5 \\
\hline strong & 79.9 & 64.6 & 73.5 \\
\hline believe in equal rights & 75.7 & 60.8 & 70.6 \\
\hline good sports & 69.7 & 71.9 & 70.6 \\
\hline sense of humour & 50.0 & 56.9 & 62.9 \\
\hline co-ordinated & 81.3 & 78.0 & 79.9 \\
\hline leacership ability & 70.0 & 60.0 & 55.8 \\
\hline fast & 72.5 & 72.3 & 72.4 \\
\hline harG-horking & 84.9 & 75.4 & 20.9 \\
\hline decicated & 66.7 & 71.5 & 80.3 \\
\hline $\begin{array}{c}\text { willing to try rew } \\
\text { things }\end{array}$ & 74.7 & 65.8 & 71.0 \\
\hline
\end{tabular}

Following attributes were belcw the 50 percent inclusion criterion on cverall ranking:

$\begin{array}{llll}\text { nasculire } & 42.2 & 41.5 & 41.9 \\ \text { loug } & 44.7 & 45.0 & 44.8 \\ \text { pushy } & 45.3 & 45.8 & 45.5 \\ \text { not very intelligent } & 24.4 & 26.2 & 25.2 \\ \text { rough } & 37.5 & 37.7 & 37.6 \\ \text { less capable than men } & 18.6 & 46.9 & 30.5 \\ \text { conceiteo } & 35.9 & 34.2 & 35.3\end{array}$




\section{DPEDSIX III}

Table 4. Ifear fercentace ratings of attritutes frcm the attribute listing task cescribing SRY OEJECnS

\begin{tabular}{|c|c|c|c|}
\hline Attribute & Female ss & fiale $3 \mathrm{~s}$ & Cverali \\
\hline beautiEul & 80.4 & 90.4 & 84.6 \\
\hline good figlires & 36.1 & 92.3 & 88.7 \\
\hline attentive to appearance & 89.3 & 86.0 & 87.9 \\
\hline Eashion conscious & 88.5 & 88.5 & 88.5 \\
\hline sec̈lictive & 75.0 & 79.2 & 76.8 \\
\hline wear heavy make-up & 75.8 & 66.2 & 72.4 \\
\hline seek attention & 78.6 & 72.7 & 76.1 \\
\hline dress secuctively & 83.8 & 81.9 & 83.0 \\
\hline Qut on an act & 70.3 & 58.8 & 65.5 \\
\hline flaunt themselves & 70.8 & 66.9 & 69.2 \\
\hline teasers & 61.0 & 54.6 & 58.3 \\
\hline long hair & 65.7 & 70.8 & 68.4 \\
\hline classy iriage & 59.4 & 59.2 & 69.4 \\
\hline neciur height & 54.4 & 66.2 & 65.2 \\
\hline unpopular with women & 62.5 & 51.2 & 57.7 \\
\hline manifulate men & 62.8 & 62.7 & 62.7 \\
\hline well-aressed & 66.2 & 71.2 & 68.3 \\
\hline vain & 66.3 & 49.2 & 59.1 \\
\hline aggressive & 52.9 & 62.3 & 56.8 \\
\hline bolc & 59.2 & 58.1 & 58.7 \\
\hline outcoing & 69.3 & 71.5 & 70.2 \\
\hline flirtacious & 70.9 & 61.2 & 56.6 \\
\hline large breasts & 64.2 & 68.5 & 66.0 \\
\hline popular & 69.6 & 77.7 & 73.0 \\
\hline socialize more with men & 71.5 & 75.0 & 73.0 \\
\hline liberal-minced & 59.9 & 65.0 & 62.0 \\
\hline promiscuols & 55.2 & 62.7 & 58.4 \\
\hline sophisticated & 52.2 & 51.9 & 52.1 \\
\hline configent & 67.5 & 65.4 & 66.6 \\
\hline morally loose & 54.9 & 58.1 & 56.2 \\
\hline inteligent & 57.9 & 67.7 & 62.0 \\
\hline
\end{tabular}

Following attritutes were below the 50 percent inclusion criterion on overall rarking:

durib blondes

not very intelligent insecure

poor early background
52.8

47.6

44.5

45.3
36.5

41.5

50.8

43.1
46.0

45.1

47.2

4.4 .4 
BEPEPTIY III

Takle 5. Pean Eercentace retircs oi attributes irom the attribute listing task cegcribing roprels LIBEFE

\begin{tabular}{|c|c|c|c|}
\hline Attribute & Female Ss & :ale $S \bar{s}$ & Guera II \\
\hline 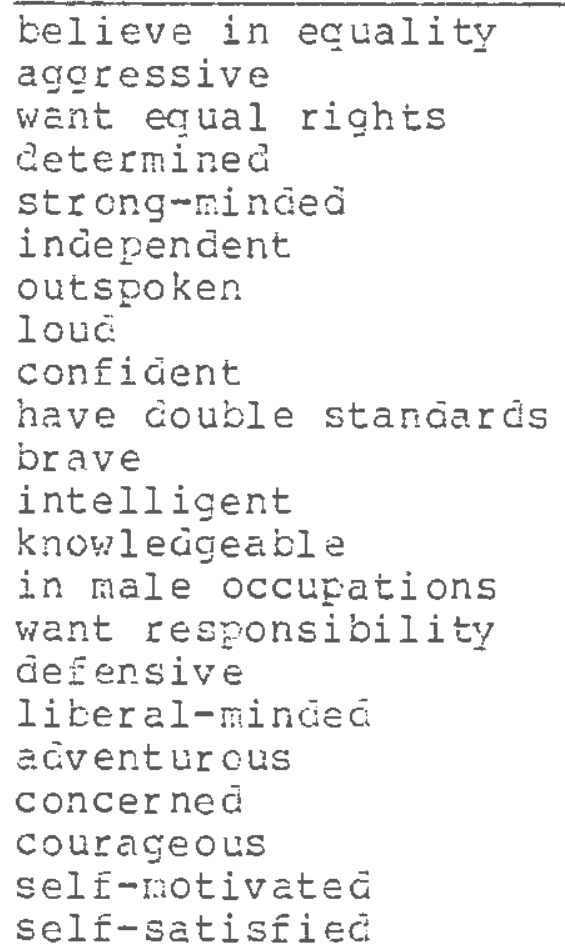 & $\begin{array}{l}90.5 \\
75.6 \\
93.1 \\
81.8 \\
81.6 \\
77.1 \\
70.1 \\
54.3 \\
75.4 \\
44.2 \\
66.5 \\
74.4 \\
75.4 \\
57.1 \\
75.7 \\
71.1 \\
70.1 \\
58.2 \\
70.6 \\
65.5 \\
67.5 \\
57.1\end{array}$ & $\begin{array}{l}88.8 \\
75.4 \\
84.6 \\
74.2 \\
75.6 \\
63.8 \\
60.4 \\
56.2 \\
63.7 \\
65.8 \\
52.7 \\
53.5 \\
65.0 \\
53.8 \\
67.3 \\
50.8 \\
65.8 \\
56.9 \\
63.5 \\
55.4 \\
53.8 \\
40.0\end{array}$ & $\begin{array}{l}69.7 \\
75.5 \\
89.4 \\
79.5 \\
76.6 \\
71.3 \\
65.9 \\
59.4 \\
59.9 \\
53.5 \\
51.7 \\
69.7 \\
70.9 \\
55.5 \\
72.1 \\
65.6 \\
68.2 \\
67.7 \\
67.5 \\
61.1 \\
61.6 \\
49.7\end{array}$ \\
\hline
\end{tabular}


Table 6. liear percentage ratings oz attributes from the attribute listing task describing HCHSETYES

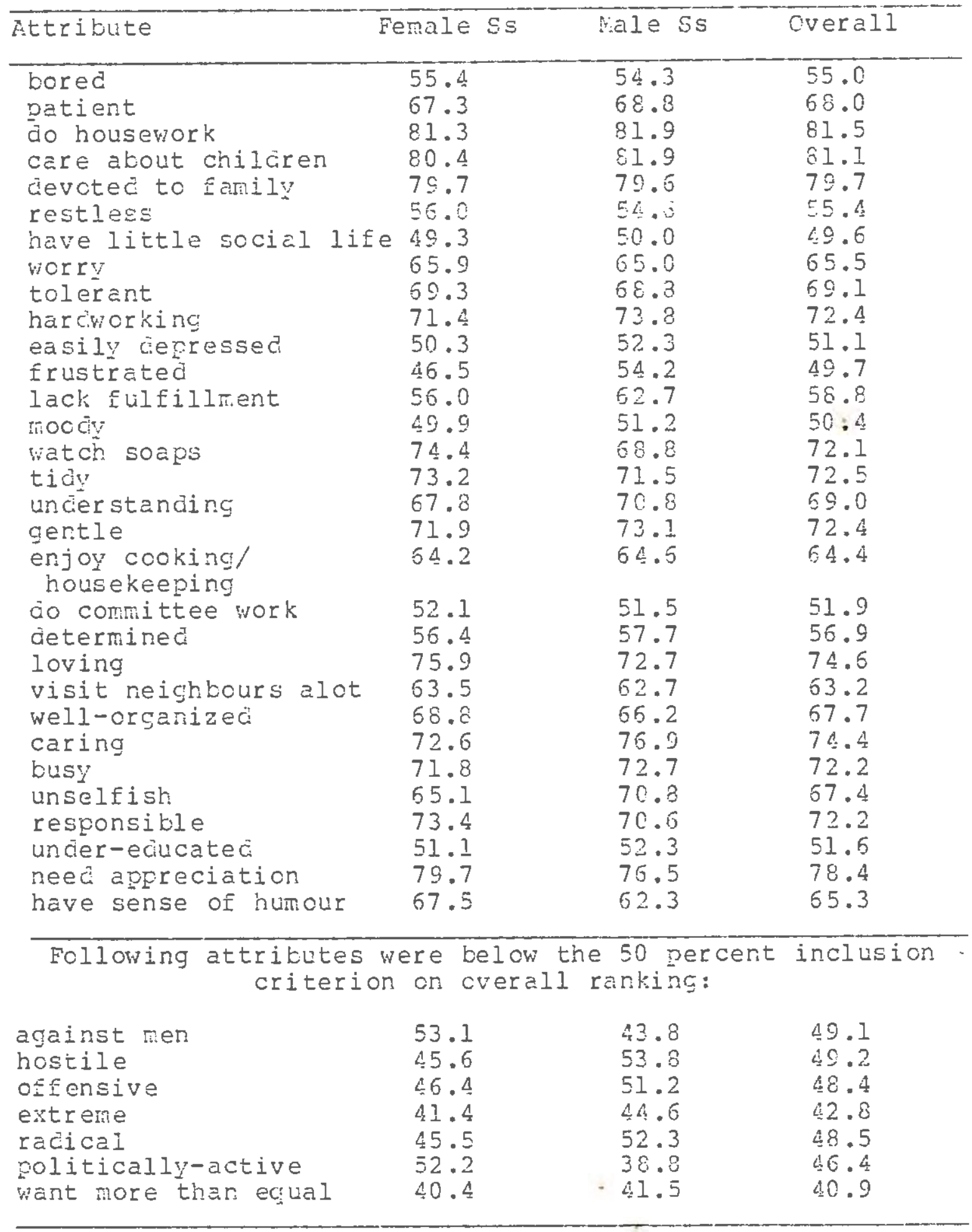




\section{APPENDIY III}

Table 7 . Nean percentage ratincs of attributes from the attribute listing task descriking nOVIE GTARs

\begin{tabular}{|c|c|c|c|}
\hline Ettribute & Female Ss & Vale Ss & Overa.l1 \\
\hline $\begin{array}{l}\text { Caring } \\
\text { loving } \\
\text { good looking } \\
\text { marriage breakdowns } \\
\text { snobbish } \\
\text { sexy } \\
\text { rich } \\
\text { intelligent } \\
\text { glanorcus } \\
\text { conceited } \\
\text { young } \\
\text { vell-dressed } \\
\text { brave } \\
\text { talented } \\
\text { artificial } \\
\text { good figures } \\
\text { talkative } \\
\text { sophisticated } \\
\text { strong } \\
\text { flexible } \\
\text { open-minded } \\
\text { self-centred } \\
\text { good personalities } \\
\text { like attention } \\
\text { outgoing } \\
\text { overvorked }\end{array}$ & $\begin{array}{l}71.7 \\
73.3 \\
77.7 \\
76.6 \\
61.1 \\
67.8 \\
84.3 \\
73.6 \\
65.3 \\
57.2 \\
56.8 \\
75.5 \\
60.5 \\
76.4 \\
59.7 \\
71.4 \\
59.2 \\
63.6 \\
57.2 \\
58.8 \\
66.4 \\
53.3 \\
60.3 \\
77.2 \\
75.8 \\
76.5\end{array}$ & $\begin{array}{l}74.6 \\
78.1 \\
76.5 \\
68.1 \\
53.8 \\
66.3 \\
78.5 \\
73.8 \\
70.4 \\
59.2 \\
63.1 \\
80.4 \\
60.8 \\
75.3 \\
58.8 \\
73.5 \\
64.2 \\
61.5 \\
50.8 \\
59.2 \\
65.4 \\
55.8 \\
65.4 \\
73.1 \\
75.4 \\
64.2\end{array}$ & $\begin{array}{l}72.9 \\
75.3 \\
77.2 \\
73.0 \\
58.1 \\
67.2 \\
81.9 \\
73.7 \\
57.4 \\
58.1 \\
59.5 \\
77.5 \\
60.6 \\
75.1 \\
57.7 \\
72.3 \\
61.3 \\
62.7 \\
54.5 \\
60.6 \\
66.0 \\
54.4 \\
62.4 \\
75.5 \\
75.6 \\
71.4\end{array}$ \\
\hline
\end{tabular}

Following attributes were below the 50 percent inclusion criterion on overall ranking:

$\begin{array}{llll}\text { no self-respect } & 27.2 & 33.8 & 30.0 \\ \text { fickle } & 43.3 & 50.0 & 46.2 \\ \text { nervous } & 43.0 & 40.4 & 42.0\end{array}$


Table 8 . liean percentage ratings of attributes from the attribute listing task cescribing PIRYPOY BUMNISS

\begin{tabular}{|c|c|c|c|}
\hline Attribute & Eemale Ss & Vale Ss & Overall \\
\hline $\begin{array}{l}\text { goodlooking } \\
\text { not shy } \\
\text { bold } \\
\text { good figures } \\
\text { sexully active } \\
\text { fun loving } \\
\text { outgoing } \\
\text { secuctive } \\
\text { cress secuctively } \\
\text { aggressive } \\
\text { conceited } \\
\text { sexually open-minded } \\
\text { nice personalities } \\
\text { like attention } \\
\text { yourg } \\
\text { heavy make-up } \\
\text { forward } \\
\text { confident } \\
\text { friencly } \\
\text { extraverted } \\
\text { morally-loose } \\
\text { sexually knowledgeable } \\
\text { egotistical } \\
\text { party-going } \\
\text { tease men } \\
\text { use sex for money } \\
\text { at ease with men } \\
\text { arink/ smoke } \\
\text { single }\end{array}$ & $\begin{array}{l}85.8 \\
87.2 \\
76.0 \\
92.6 \\
88.1 \\
78.8 \\
77.1 \\
81.6 \\
74.4 \\
57.6 \\
63.6 \\
85.3 \\
63.3 \\
83.6 \\
89.7 \\
71.3 \\
66.4 \\
69.4 \\
68.3 \\
55.6 \\
58.1 \\
84.4 \\
50.3 \\
75.2 \\
68.6 \\
57.2 \\
82.7 \\
71.1 \\
78.0\end{array}$ & $\begin{array}{l}91.5 \\
85.0 \\
74.9 \\
93.7 \\
88.5 \\
82.7 \\
79.6 \\
60.0 \\
85.4 \\
59.6 \\
60.0 \\
79.5 \\
70.0 \\
76.2 \\
86.2 \\
56.9 \\
71.2 \\
66.5 \\
73.8 \\
70.0 \\
64.2 \\
77.6 \\
51.5 \\
75.4 \\
65.0 \\
40.4 \\
75.9 \\
70.4 \\
84.2\end{array}$ & $\begin{array}{l}88.2 \\
86.3 \\
75.5 \\
93.1 \\
88.2 \\
80.4 \\
78.2 \\
80.9 \\
79.0 \\
58.4 \\
62.1 \\
82.9 \\
66.1 \\
80.5 \\
88.2 \\
65.3 \\
68.4 \\
68.2 \\
70.5 \\
61.3 \\
60.6 \\
81.6 \\
56.6 \\
75.3 \\
67.1 \\
50.2 \\
80.3 \\
70.8 \\
80.6\end{array}$ \\
\hline
\end{tabular}

Following attributes were below the 50 percent inclusion criterion on overall ranking:

$\begin{array}{llll}\text { not intelligent } & 44.7 & 45.8 & 45.2 \\ \text { dumb blondes } & 52.8 & 35.4 & 45.5 \\ \text { insecure } & 38.3 & 48.5 & 42.6 \\ \text { no self-respect } & 39.6 & 31.5 & 36.2 \\ \text { can't think for } & 39.4 & 40.3 & 40.0 \\ \quad \text { themselves } & 47.8 & 43.5 & 46.0 \\ \text { not Iiberated } & & & \end{array}$


PPDEMTIZ III

Table 9. Nean percentage ratincts of attritutes from the attribute listing task c'escribing FG'AIE TEACEPS

\begin{tabular}{|c|c|c|c|}
\hline P.ttributo & Eemale SS & :ale Ss & Over $\bar{c} .11$ \\
\hline $\begin{array}{l}\text { patient } \\
\text { uncerstancing } \\
\text { intelligent } \\
\text { symeathetic } \\
\text { neat } \\
\text { able-to-control } \\
\text { friencly } \\
\text { responsible } \\
\text { competent } \\
\text { well-orcanized } \\
\text { well-grconed } \\
\text { good-hith-youns } \\
\text { helpful } \\
\text { goal-oriented } \\
\text { hard-working } \\
\text { dedicated } \\
\text { eficicient } \\
\text { incepencient } \\
\text { trustworthy } \\
\text { like their job } \\
\text { well-spoken } \\
\text { tolerant }\end{array}$ & $\begin{array}{l}71.9 \\
70.0 \\
80.6 \\
67.5 \\
71.7 \\
69.7 \\
72.2 \\
78.6 \\
73.6 \\
74.7 \\
75.8 \\
72.9 \\
70.4 \\
67.2 \\
72.5 \\
71.9 \\
73.2 \\
53.9 \\
69.7 \\
69.7 \\
74.4 \\
63.9\end{array}$ & $\begin{array}{l}70.8 \\
68.5 \\
77.3 \\
68.3 \\
74.6 \\
61.7 \\
73.5 \\
76.2 \\
70.4 \\
77.3 \\
76.2 \\
73.8 \\
76.9 \\
70.8 \\
76.5 \\
74.6 \\
72.7 \\
55.8 \\
76.3 \\
75.4 \\
75.8 \\
62.7\end{array}$ & $\begin{array}{l}71.5 \\
59.4 \\
79.2 \\
67.8 \\
72.9 \\
66.5 \\
72.7 \\
77.5 \\
72.3 \\
75.8 \\
76.0 \\
73.3 \\
73.2 \\
68.7 \\
74.2 \\
73.1 \\
73.0 \\
60.5 \\
72.3 \\
72.1 \\
75.0 \\
66.3\end{array}$ \\
\hline
\end{tabular}

Eollowing attributes were below the 50 percent inclusion criterion on overall ranking:

nervous

35.6

42.7

38.5 


\section{ADPERTIY III}

Table 10. Mean percentage ratings of attributes from the attritute listing task cescribing FElaLE IOCrCRS

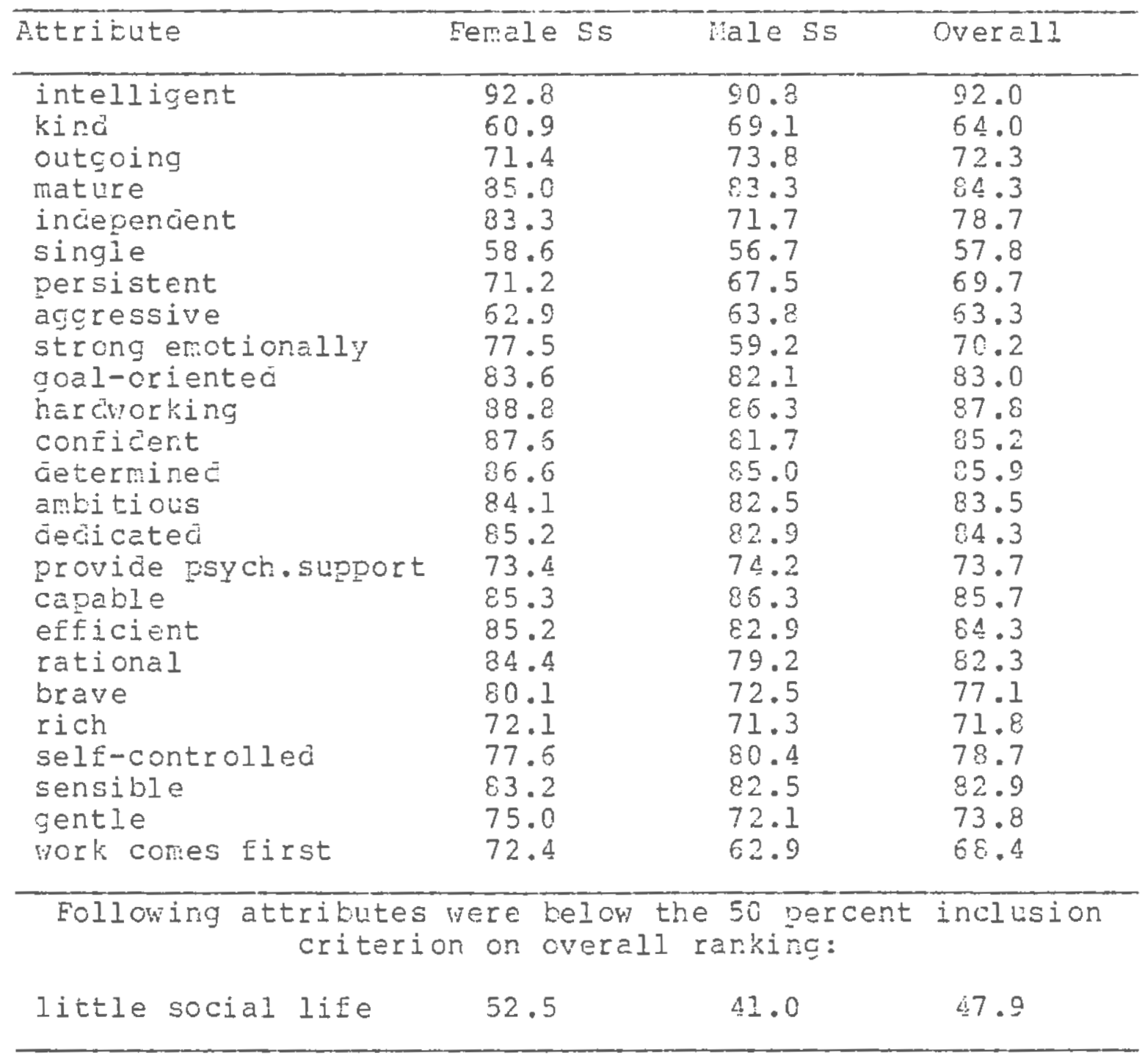




\section{APEDDIY III}

rable 11. Hean percentage ratings of attributes from the attriblte listirg task cescribira FElMLE Dutillas

\begin{tabular}{|c|c|c|c|}
\hline Attribute & Fenale ss & :ZaleSs & Overali \\
\hline $\begin{array}{l}\text { healthy } \\
\text { competitive } \\
\text { active } \\
\text { outcoing } \\
\text { sense of achievement } \\
\text { ambitious } \\
\text { have proper ciet } \\
\text { strong-illed } \\
\text { dedicated } \\
\text { incepencient } \\
\text { tall } \\
\text { strorg } \\
\text { determined } \\
\text { prouci } \\
\text { pro equal rights } \\
\text { non-smoker/ crinker } \\
\text { harc-worker } \\
\text { short hair } \\
\text { muscular } \\
\text { intelligent } \\
\text { self-disciplined } \\
\text { seli-controlled } \\
\text { don't use nake-up } \\
\text { liberated } \\
\text { strive for perfection } \\
\text { involved in other } \\
\text { activities }\end{array}$ & $\begin{array}{l}91.3 \\
87.5 \\
89.3 \\
81.1 \\
81.7 \\
80.4 \\
88.4 \\
86.4 \\
88.5 \\
77.2 \\
71.6 \\
82.8 \\
85.4 \\
70.8 \\
68.4 \\
98.1 \\
88.8 \\
70.5 \\
76.7 \\
78.3 \\
84.7 \\
81.9 \\
50.8 \\
70.3 \\
77.4 \\
63.3\end{array}$ & $\begin{array}{l}88.8 \\
79.9 \\
80.8 \\
66.5 \\
75.8 \\
71.5 \\
80.0 \\
78.8 \\
76.5 \\
59.2 \\
58.8 \\
62.3 \\
91.2 \\
62.3 \\
55.0 \\
81.9 \\
82.2 \\
62.7 \\
56.2 \\
70.0 \\
76.9 \\
72.7 \\
52.1 \\
55.8 \\
65.0 \\
67.7\end{array}$ & $\begin{array}{l}90.3 \\
84.3 \\
85.7 \\
75.0 \\
79.2 \\
76.7 \\
84.9 \\
83.2 \\
83.3 \\
69.7 \\
66.2 \\
74.2 \\
83.6 \\
67.3 \\
62.8 \\
85.5 \\
86.0 \\
67.2 \\
58.1 \\
74.8 \\
81.4 \\
78.1 \\
51.4 \\
54.2 \\
72.2 \\
65.2\end{array}$ \\
\hline $\begin{array}{r}\text { Following attritute } \\
\text { criter }\end{array}$ & $\begin{array}{l}\text { were below th } \\
\text { in on overall }\end{array}$ & $\begin{array}{l}\text { e } 50 \text { vercent } \\
\text { ranking: }\end{array}$ & inclusicn \\
\hline $\begin{array}{l}\text { masculine } \\
\text { boring } \\
\text { esotistical } \\
\text { linited social life }\end{array}$ & $\begin{array}{l}47.5 \\
34.8 \\
39.3 \\
50.0\end{array}$ & $\begin{array}{l}34.2 \\
35.5 \\
37.3 \\
38.8\end{array}$ & $\begin{array}{l}41 \cdot 9 \\
35 \cdot 1 \\
38 \cdot 5 \\
45 \cdot 5\end{array}$ \\
\hline
\end{tabular}


ADPEPLIY III

Table 12. Fear Lercentace rating of attributes fror the

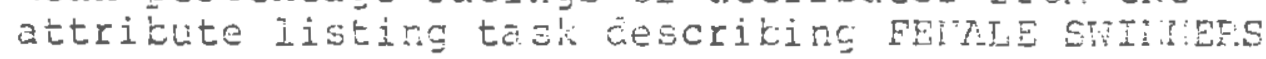

\begin{tabular}{|c|c|c|c|}
\hline Attribute & Eemale $S \mathrm{~s}$ & Tale ss & overail \\
\hline 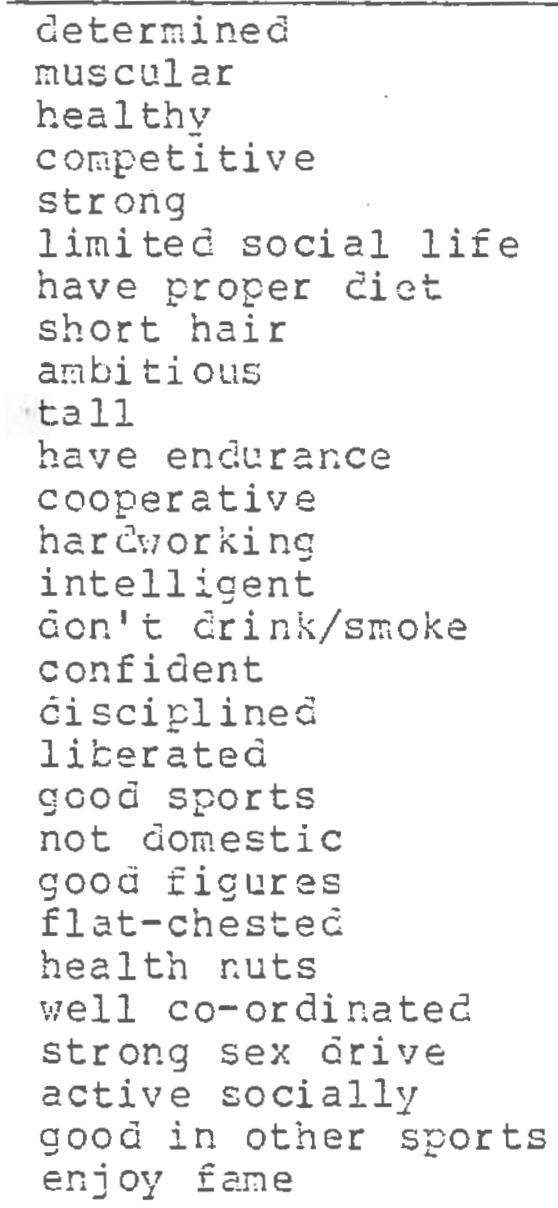 & $\begin{array}{l}88.1 \\
83 \cdot 5 \\
91 \cdot 1 \\
91 \cdot 9 \\
88.3 \\
68.6 \\
85.7 \\
80.8 \\
79.1 \\
63.8 \\
85.9 \\
69.7 \\
83.7 \\
79.3 \\
78.1 \\
80.0 \\
86.7 \\
69.7 \\
73.9 \\
54.7 \\
67.5 \\
53.8 \\
58.5 \\
73.4 \\
60.6 \\
56.5 \\
66.9 \\
66.4\end{array}$ & $\begin{array}{l}83.5 \\
66.2 \\
86.5 \\
84.6 \\
80.4 \\
57.3 \\
81.2 \\
80.4 \\
79.2 \\
71.2 \\
76.5 \\
77.5 \\
83.1 \\
75.0 \\
77.3 \\
77.3 \\
81.2 \\
65.8 \\
76.9 \\
63.5 \\
73.5 \\
56.2 \\
53.5 \\
80.3 \\
53.1 \\
51.9 \\
75.4 \\
75.0\end{array}$ & $\begin{array}{l}86.1 \\
76.3 \\
39.2 \\
88.8 \\
85.0 \\
63.0 \\
83.8 \\
80.6 \\
79.2 \\
66.9 \\
82.0 \\
73.0 \\
83.5 \\
77.5 \\
77.7 \\
78.9 \\
84.4 \\
68.1 \\
75.2 \\
58.4 \\
70.0 \\
54.8 \\
56.4 \\
79.4 \\
57.3 \\
54.6 \\
70.5 \\
70.0\end{array}$ \\
\hline
\end{tabular}


APPEIIIX III

Table 13. Nean percentage ratings of attributes from the attribute listing task ciescribing I:ODERATES COMIITTED TO EOUAI, RIGHTS

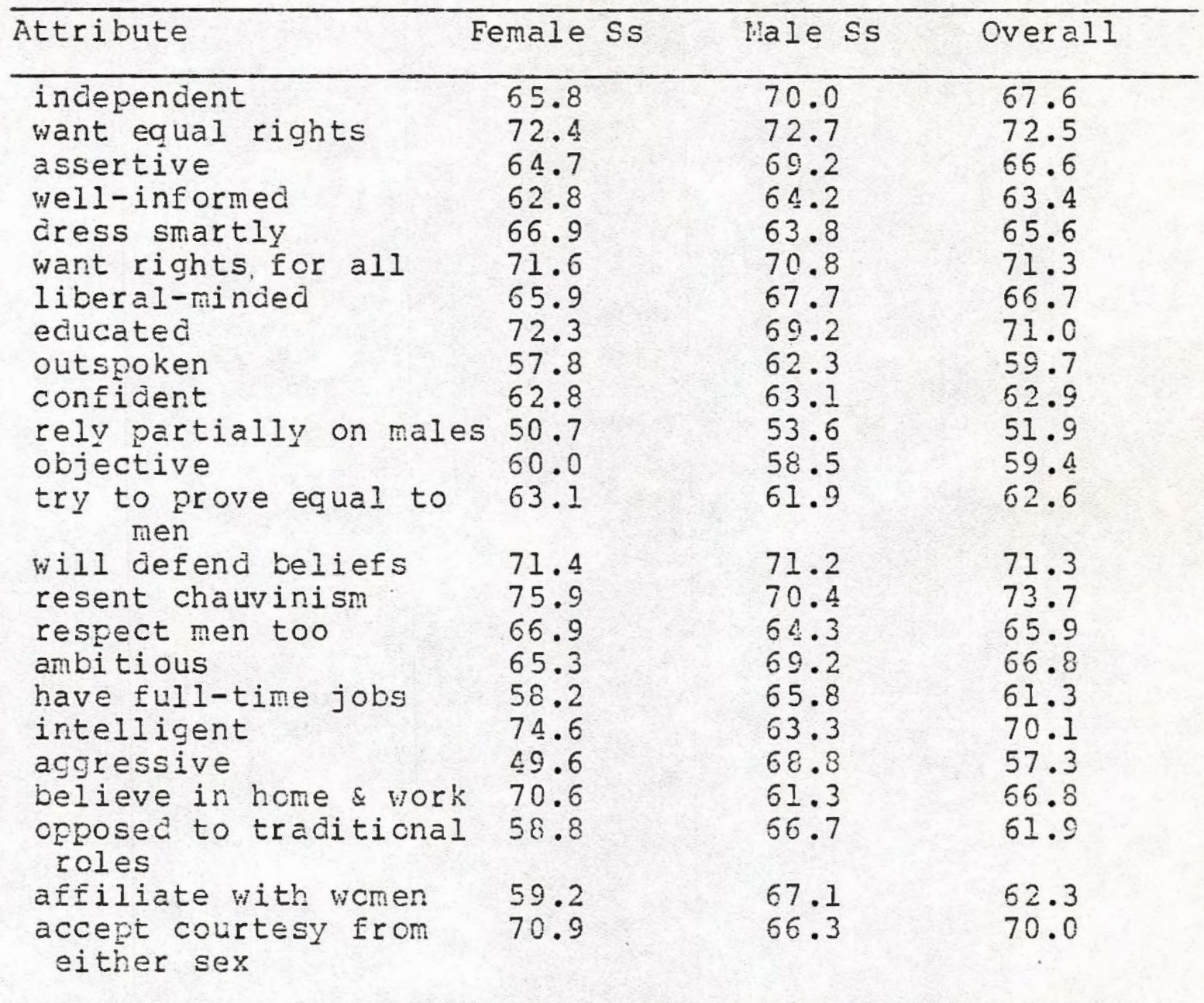

Following attributes vere below the 50 percent inclusion criterion on overall ranking:

politically active don't have a family
41.1

40.5
46.2

41.3
43.2

40.8 


\section{APPEVIIT III}

Table 1. Hean Fercentage ratings of ettribltes Eron the attricute listing task cescribing RñICR

SUPEORTEIS CE PORTA'S PIGETS

\begin{tabular}{|c|c|c|c|}
\hline Attribute & Fenale Ss & Wale Ss & Ov $\subseteq$ all \\
\hline $\begin{array}{l}\text { outspoken } \\
\text { determined } \\
\text { unmerried } \\
\text { incependent } \\
\text { uant equality } \\
\text { aggressive } \\
\text { opposed to male/female } \\
\text { roles } \\
\text { confident } \\
\text { outgoing } \\
\text { antitious } \\
\text { educated } \\
\text { intelligent } \\
\text { strong-mincec } \\
\text { act superior } \\
\text { ajedicated } \\
\text { believe in change } \\
\text { career-oriented } \\
\text { emotional } \\
\text { strons-voicec } \\
\text { Iiberal-minci }\end{array}$ & $\begin{array}{l}76.9 \\
83.0 \\
58.8 \\
78.2 \\
88.4 \\
70.0 \\
78.6 \\
76.9 \\
80.8 \\
76.4 \\
75.4 \\
75.8 \\
73.4 \\
49.2 \\
72.5 \\
80.5 \\
79.7 \\
48.3 \\
75.4 \\
79.2\end{array}$ & $\begin{array}{l}76.2 \\
78.5 \\
66.5 \\
71.9 \\
86.8 \\
78.8 \\
71.5 \\
71.5 \\
75.8 \\
76.5 \\
73.5 \\
75.0 \\
78.8 \\
55.0 \\
73.1 \\
78.8 \\
76.5 \\
61.5 \\
75.4 \\
70.0\end{array}$ & $\begin{array}{l}76.5 \\
81.1 \\
62.1 \\
75.5 \\
87.8 \\
73.7 \\
75.6 \\
74.7 \\
78.2 \\
76.5 \\
74.6 \\
75.5 \\
78.6 \\
51.5 \\
72.7 \\
79.8 \\
78.4 \\
53.9 \\
75.4 \\
75.3\end{array}$ \\
\hline
\end{tabular}


ADPDEIX IIT

Table 15. Hear cercentage ratings of attributes from the

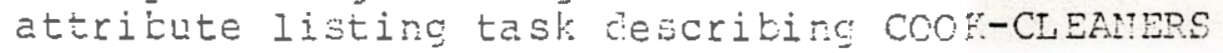

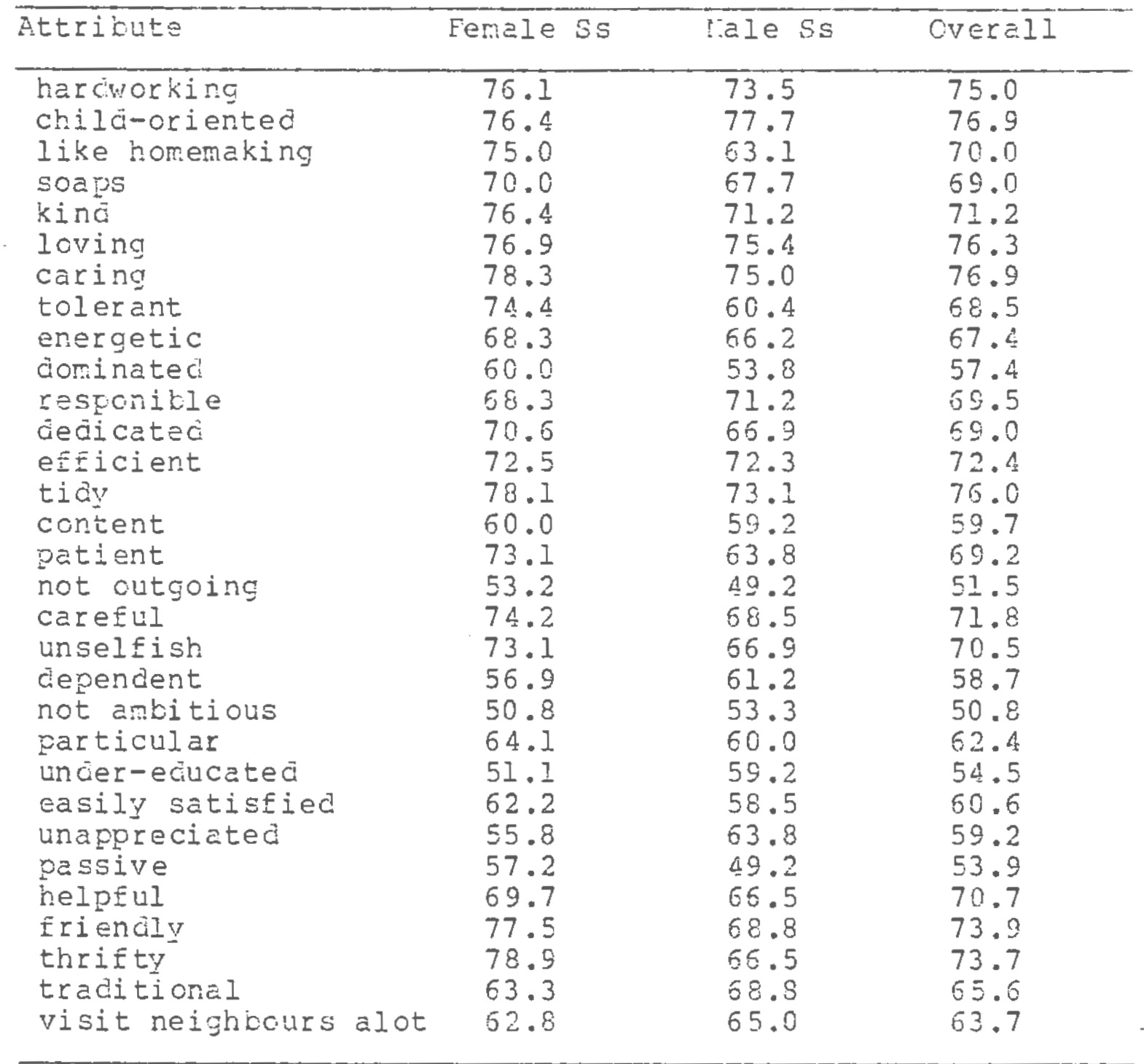

Following attributes were below the 50 percent inclusion criterion on overall ranking:

$\begin{array}{llll}\text { homely } & 44.7 & 51.2 & 47.4 \\ \text { bored } & 44.2 & 47.8 & 45.7 \\ \text { narrow-minced } & 45.0 & 47.7 & 46.1 \\ \text { nagging } & 44.4 & 46.2 & 45.1 \\ \text { cuiet } & 53.1 & 41.9 & 48.4\end{array}$




\section{APPENDIX III}

mable 16. Mean percentage ratings of attributes fror. the attribute listing task describing CAPETAKEPS

OF CHILIRE:

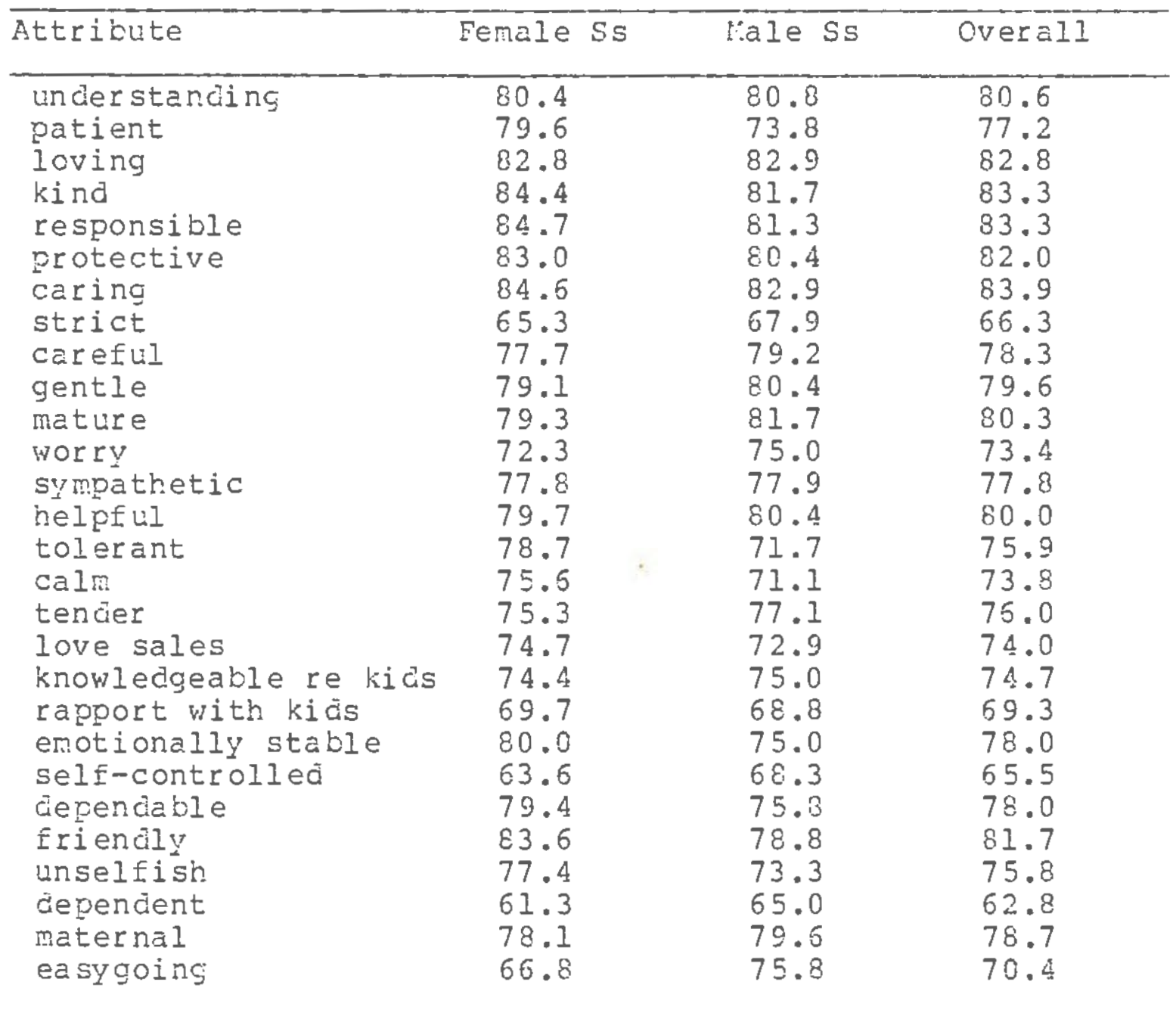

Following attributes were below the 50 percent inclusion criterion on overall rarking:
nervous
41.4
$51 \cdot 3$
45.3 
APPENDIY IV

Example Test Booklet for Catecory Maning Mask 
Sex

Ace

Each of the following pages has a short list of attributes that coula be used to characterize a particular type of person. Reac the list carefully, and then, from the alternatives provided, check the term that you think would be most frequently used to cescribe that gerson. (Circle one alternative onI

Do not look through all the pages first. Turn each page only after you have Einishec it. 
Attribute list:

beautiful

good figure

attentive to appearance

Eashicn-conscicus

seductive

heavy makeup

seeks attention

dresses seductively

popular

socializes more with men

The term you wolld most frequently use to cescribe this tyre of verson is:
a. a female attilete
b. a monan
c. a sex-object
c. a novie-star 
Attriblte list:

arntitions

non-smoker/non-cirinker

healthy

erergetic

sports-oriented

slin

co-ordinated

ciecicated

determined

har ciworking

The term that you woulc most frequently use to cescrike this type of person is:
a. a İemale runner
b. a Ferale athlete
c. a vonan
c. a women's Iibber 
Attribute list:

believes in equality

aggressive

determined

wants equal rights

strong-minàeä

inciepencient

knowledgeable

wants resfonsibility

aciventurous

defersive

The term that you would most frequently use to cescribe this type of verson is:
a. a women
b. a yomer's libber
c. a sex-object
d. a mocierate comittec to equal rights 
Attribute 1 ist:

inte 11 igent

college-educated

ambitious

determined

harcuorking

mature

responsible

liberated

goal-oriented

competent

$\operatorname{logice} 1$

The term that you boulo most freciuently use to cescribe this type of person is:
a. a career womar.
b. a woman
c. a female teacher
a. a houserife 
Attribute Iist:

cares about chilcren

cevotec to ianily

cioes housework

harciorking

$\operatorname{ticy}$

gentle

icving

busy

caring

neeçs appreciation

The term that you would nost Erectenty use to cecribe this type of zerson is:
a. a cock-cleaner
c. a housenire
c. à women
ci. a female athlete 
APPEIDTZ Y

Sex-role scale and Factor Analyses 
Se:-

Ace

Pate each of the follorirg attributes accorcing to hor

tyaical you think each is of holseyides. For each scale, circle the number that best raresents your opirion. For example, if you think that sincere is nociertely tyical o nousevives, you woulä circle 6 belcr:

$\begin{array}{cccc}1 & 2 & 3 & 4 \\ \text { cuite atypical } & \text { mocierately } & \text { slightiy } & \text { averege } \\ 5 & \text { atypical } & \text { atypical } & \end{array}$

slightly typical moderately typical guite tyical (The numbers below represent these graded sters.)

\begin{tabular}{|c|c|c|c|c|c|c|c|}
\hline anbitious & 1 & 2 & 3 & 4 & 5 & 6 & 7 \\
\hline believe ir eciuality & 1 & 2 & 3 & 4 & 5 & 6 & 7 \\
\hline intelligent & 1 & 2 & 3 & 4 & 5 & 6 & 7 \\
\hline beatitiful & 1 & 2 & 3 & 4 & 5 & 5 & 7 \\
\hline good figures & 1 & 2 & 3 & 4 & 5 & 5 & 7 \\
\hline co housework & 1 & 2 & 3 & 4 & 5 & 6 & 7 \\
\hline nonsmoker/rondrinker & 1 & 2 & 3 & 4 & 5 & 6 & $\overline{7}$ \\
\hline aggressive & 1 & 2 & 3 & 4 & 5 & $\overline{6}$ & 7 \\
\hline collece-eciucated & 1 & 2 & 3 & 4 & 5 & 6 & 7 \\
\hline care about chiliren & 1 & 2 & 3 & 4 & 5 & 6 & 7 \\
\hline enercetic & 1 & 2 & 3 & 4 & 5 & 6 & 7 \\
\hline aeternirec & 1 & 2 & 3 & 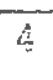 & 5 & 6 & $\overline{7}$ \\
\hline sarciorting & 1 & 2 & 3 & 4 & 5 & $\bar{E}$ & 7 \\
\hline attentive to apsearance & 1 & 2 & 3 & 4 & 5 & 6 & 7 \\
\hline Eevoted to Eanily & 1 & 2 & 3 & 4 & 5 & 6 & 7 \\
\hline healthy & 1 & 2 & 3 & 4 & 5 & 6 & $\overline{7}$ \\
\hline strong-minced & 1 & 2 & 3 & 4 & 5 & 6 & 7 \\
\hline T.ature & $I$ & 2 & 3 & 2 & 5 & 6 & $\overline{7}$ \\
\hline Fashion-consciovs & 1 & 2 & 3 & 4 & $\underline{E}$ & 3 & $\bar{i}$ \\
\hline$E i d y$ & $I$ & $\overline{2}$ & $\overrightarrow{3}$ & 4 & 5 & 6 & $\overline{7}$ \\
\hline
\end{tabular}




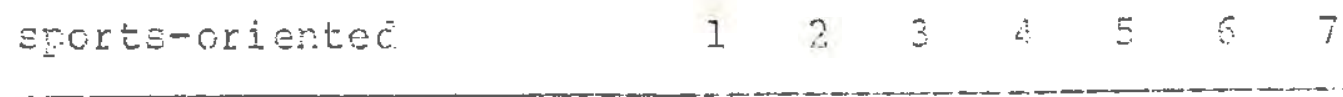

independent 1 i 3 i 57

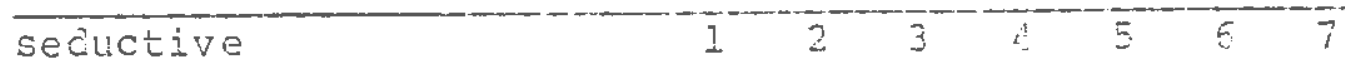

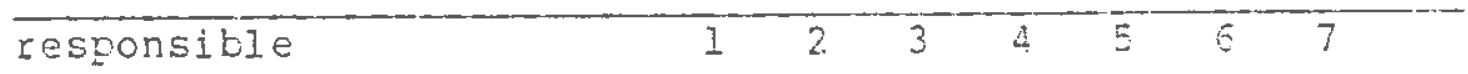

gentle $110 \begin{array}{lllllll} & 2 & 3 & 4 & 5 & 6 & 7\end{array}$

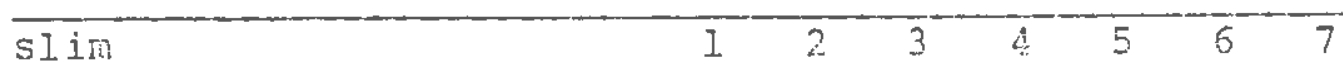

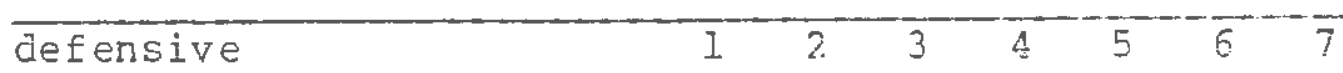

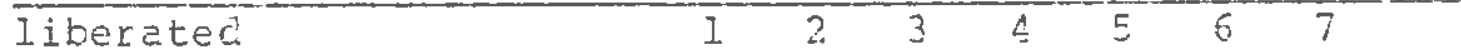

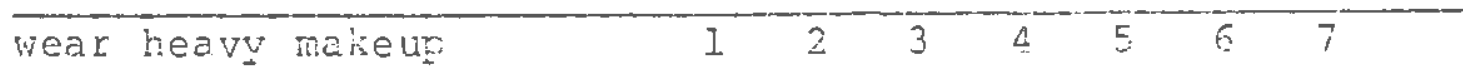

$\begin{array}{llllllll}\text { lovirg } & 1 & 2 & 3 & \vdots & 5 & 5 & 7\end{array}$

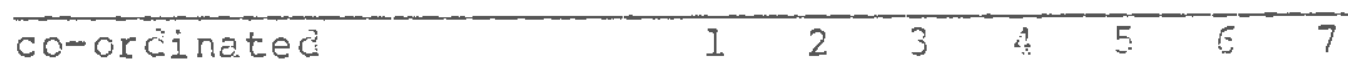

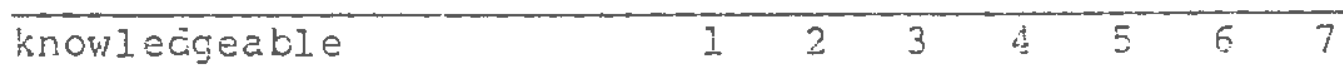

goal-oriented $\quad$\begin{tabular}{llllllll}
\hline & 2 & 3 & 4 & 5 & 6 & 7
\end{tabular}

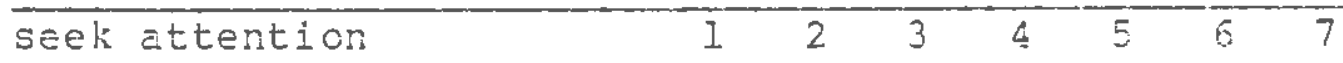

caring

$\begin{array}{lllllll}1 & 2 & 3 & 4 & 5 & 6 & 7\end{array}$

decicatec

$\begin{array}{llllll}1 & 2 & 3 & 4 & 5 & 5\end{array}$

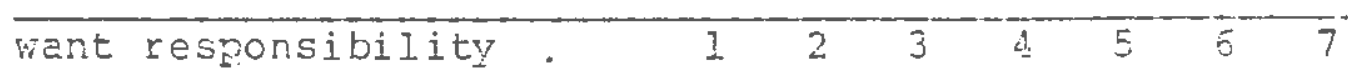

dress secuctiveiy 11237

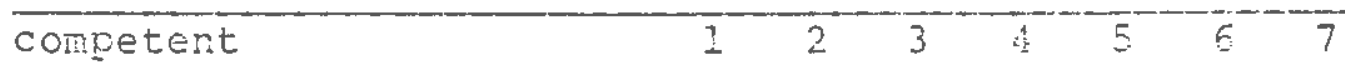

busy $\quad 1 \quad \begin{array}{llllll}4 & 3 & 4 & 5 & 5 & 7\end{array}$

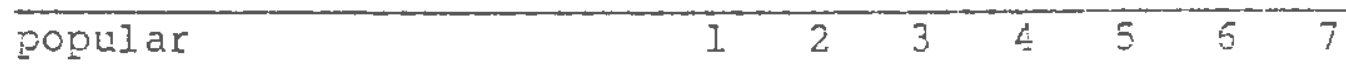

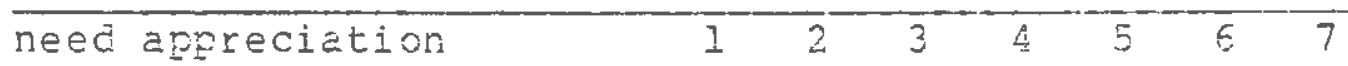

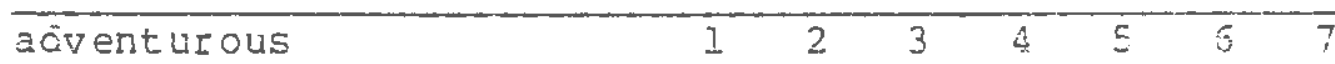

socialize more with mer: 1 2 $3 \begin{array}{lllll}4 & 5 & 6 & 7\end{array}$

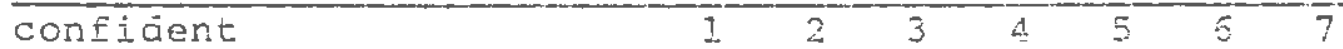




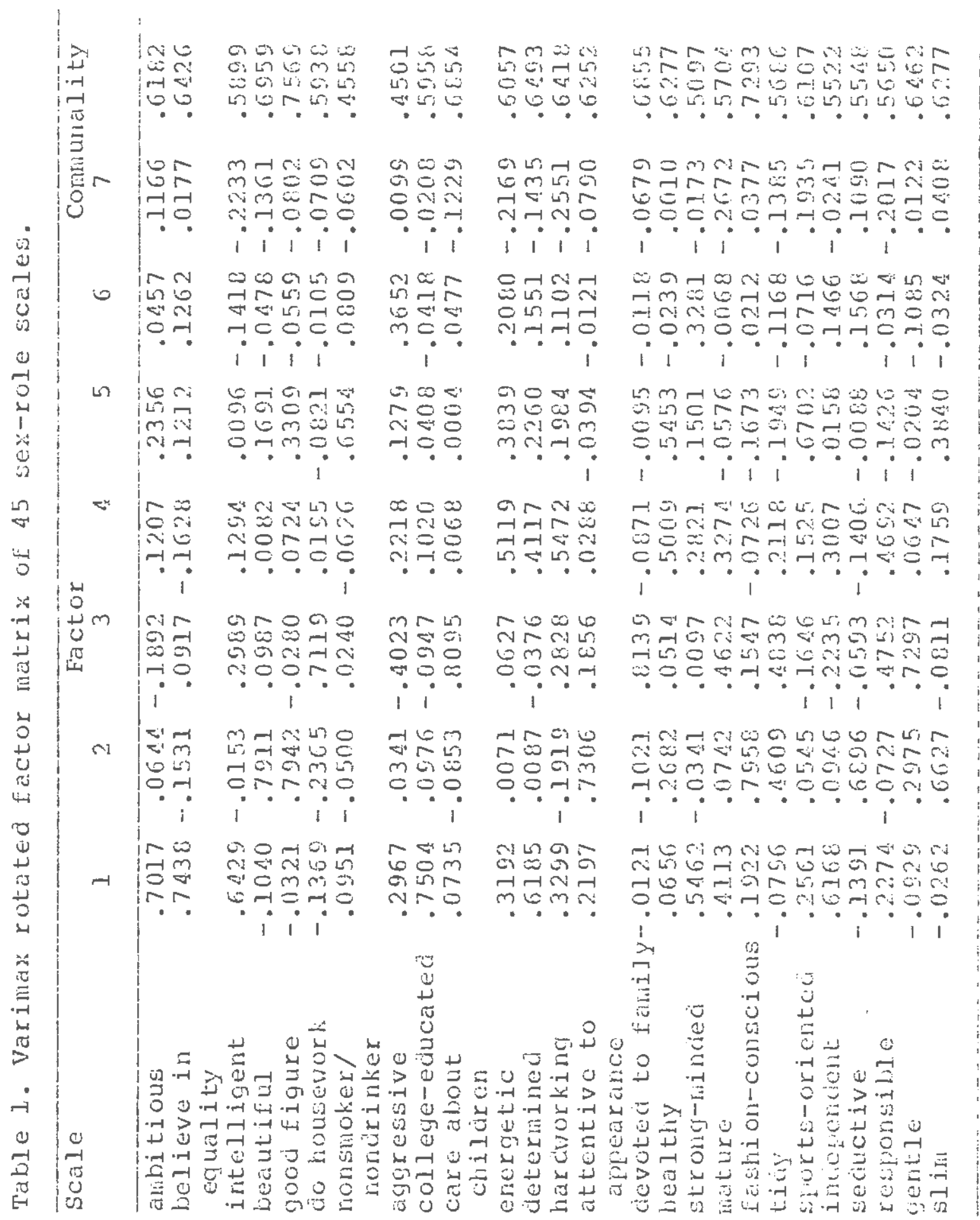




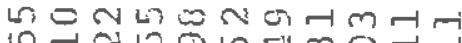

थन

6rom

年, ; เ

0

क

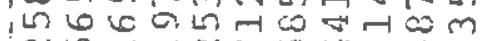

तथ

०.

11

-1 1 w

imन

*. 1.

cmonर⿻

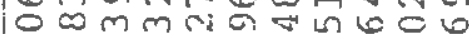
is $m$ in in

$100 \% 0 m \odot \pi 00 \pi$

(1)

$=0 m 00 \pi m \infty n$ m mल जो

Hmanorw6. $\pi$ t mmbo Oन 0 . i i

$$
i
$$

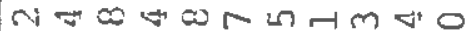
$10 m$ का

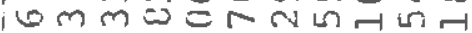

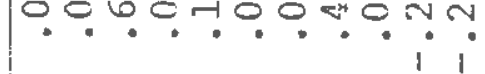

नrimin सMmONm0

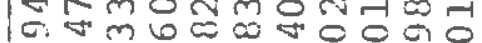

invol 0 .

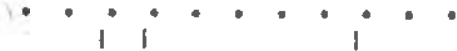

$$
\stackrel{1}{3}
$$$$
\overrightarrow{0}
$$$$
\text { 望 }
$$

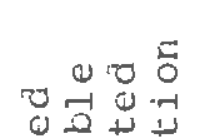

$003 \pm \sqrt{5} \overrightarrow{0}$

$\begin{array}{lllll}0 & 0 & 0 & 0 & 0 \\ 0 & 0 & 0 & 0 & 0 \\ 0 & 0 & 0 & 0\end{array}$

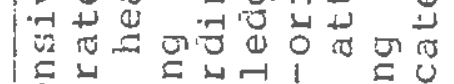

0

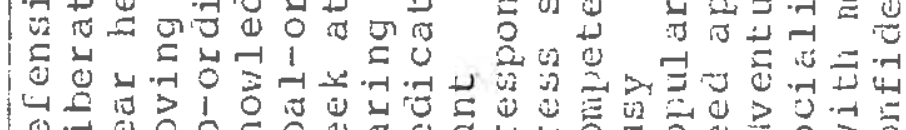

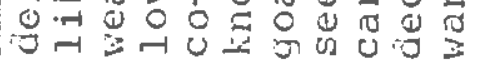

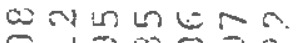

$0-\pi \infty 0=6$

Nin $=600$

$6 \& 5$ : 56

Hm

cirmm sy

(c)

$0=\pi, m \& m$

ombmr-

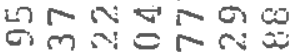

ㅁ․ㅁㄷㅜ

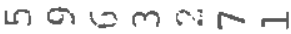

$\because \pi 0 m$ o

ONGQ日0

$\because 00 \%=\pi$

mrm- $m 0 \nabla$

$\infty \quad m 0=\pi$

ON $\mathrm{N}$ me

न

I

- $m$ m ता 0 प $\mathrm{N}=\mathrm{N}$

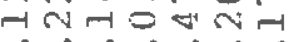

1

जm $\mathrm{m}$

EN

กन मंब

r.

in

स

mino $=m 0$

$8 \omega \pi \neq \omega 60$

$0 m N 00 \% \mathrm{r}$

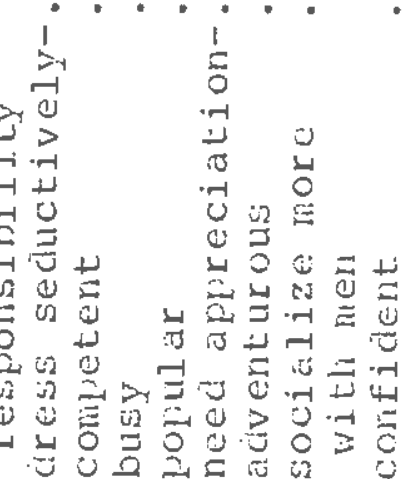

$m=$

$0 m$

$\rightarrow \mathrm{N}$

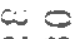

o.j $\infty$

-

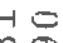

m?

-

$0=$

$m$ न

त: 4

in

66

4)

r

00

$-$

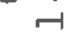

ด

50

$\approx 0$

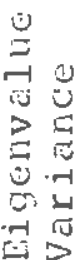

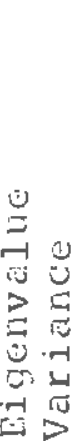




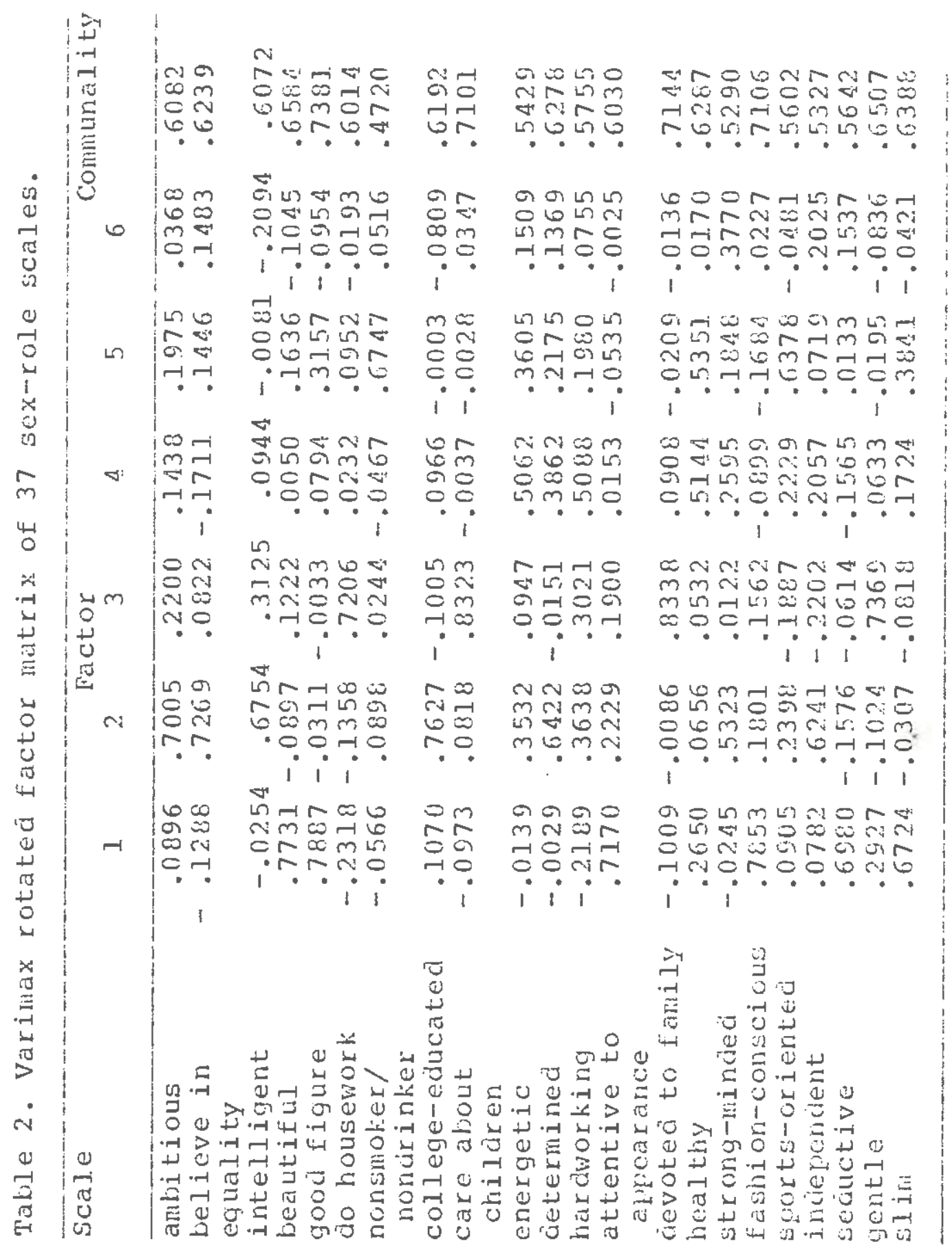




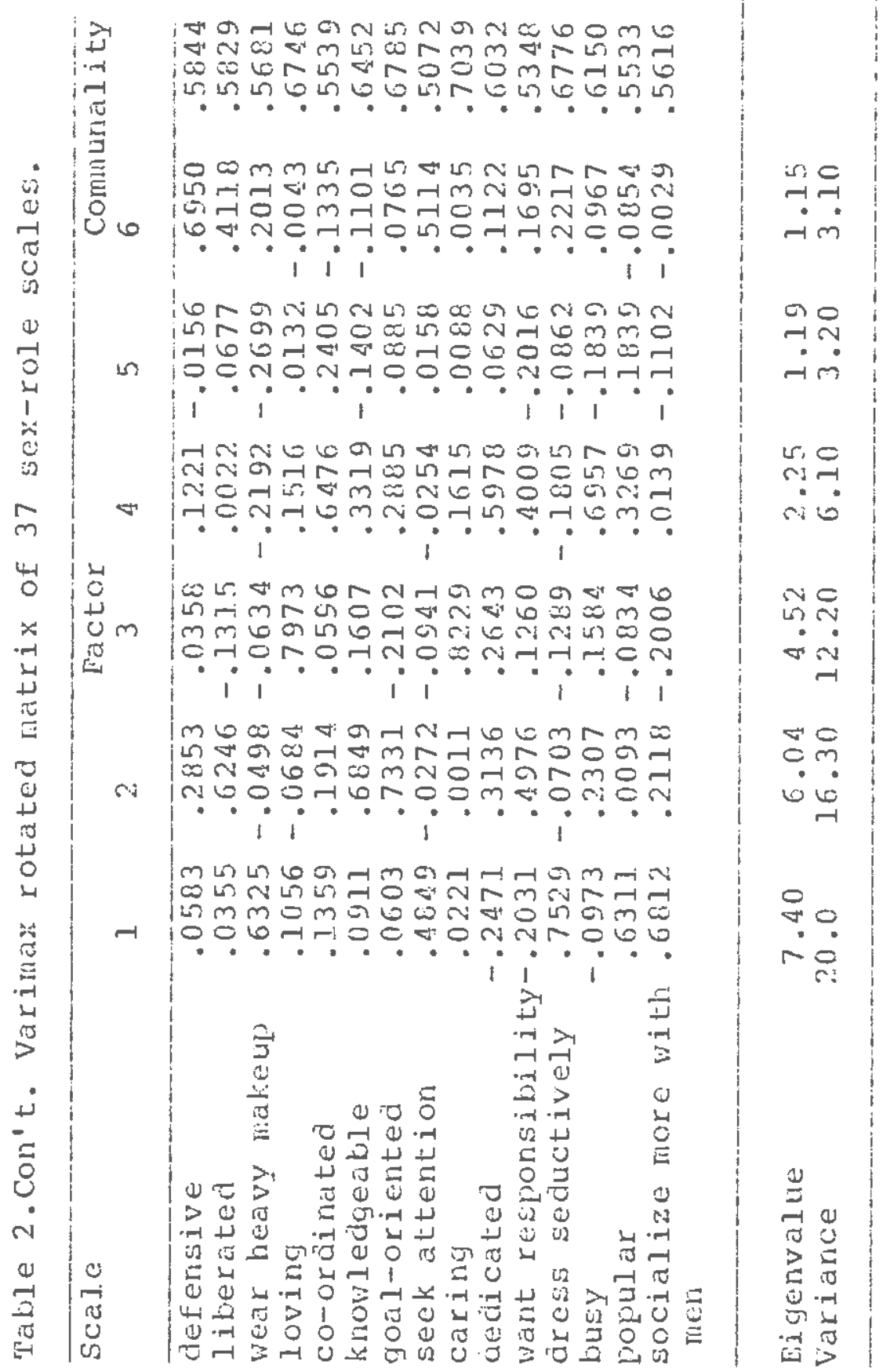

